\title{
DEFENSIVE REALISM AND CHINESE MARITIME STRATEGY
}

BY

\section{JAMES DOUGLAS}

\author{
A thesis \\ submitted to the Victoria University of Wellington \\ in fulfilment of the requirements for the degree of \\ Master of Arts
}

Victoria University of Wellington 
The development and recent operations of the People's Liberation Army Navy (PLAN) is one of the most pressing issues in the security structure of Asia. Discussions of both the Chinese Navy and China's rise generally continue to be dominated by offensive realist thinking. This theory sees China as a state seeking power, and eventually hegemony, in its region. However, defensive realism is a more nuanced explanation of China's rise and the operations of its navy. Defensive realism sees states as seeking security rather than power, valuing what they have more than what they desire.

The PLAN itself was founded in 1949 and has evolved in its focus throughout its existence. First the PLAN was focused on defending against attacks from Taiwan, then defending against a possible attack by the Soviet Union. After the cementing of the US-Sino relationship towards the end of the Cold War, and the rise of Deng Xiaoping and his economic liberalisation, the PLAN lost much of its purpose and funding which had always been minimal.

The Taiwan Strait crisis in 1995, along with other conflicts like the first Gulf War and the Kosovo War, reprioritised the navy and the need to defend against possible US intervention. This turn to the navy was heightened by economic, resource, energy and regime motivations. This has lead to an effort to modernise a PLAN fleet which was aging and incapable of what was now required of it. This modernisation is ongoing, and it is still to produce a navy which is an entirely modern and near the capability of other comparable forces. The development of para-military maritime forces is one of the most telling aspects of China's maritime development.

China's navy has engaged in two operations overseas in the past decade; anti-piracy patrols in the Gulf of Aden since 2005, and assisting in the evacuation of Chinese nationals from Libya in 2012. These two operations are not indicative of a new global role, and are instead born of the unique circumstances of the two situations. More telling are the exercises that the PLAN has engaged in since 2010, these show the PLAN's developing ability to defend territorial claims, such as the South China Sea and Taiwan.

There have also been a series of incidents at sea between China and other disputant states over maritime territory. These incidents take a different shape based on the military capabilities of the other state. South Korea and Japan can monitor these areas with large militaries, and so actions by China are low key. In comparison, claimant states in the South China Sea have ships harassed, primarily by the ships of paramilitary maritime organisations. This harassment is a strategy by China to ensure a secure claim to these areas under international law by asserting jurisdiction. Such a strategy serves to defend China's claim and prevent a negotiated settlement on anything but its own terms. Thus China's maritime strategy is based on defensive realist principles of defending territory and ensuring security, rather than seeking power. 
TABLE OF CONTENTS

Introduction

Literature Review 


\section{INTRODUCTION}

The People's Liberation Army Navy (PLAN) is an institution that can attract media attention like few other components of the People's Liberation Army (PLA). In 2008 the dispatch of two destroyers and a resupply vessel signalled to many the coming of age of the PLAN, attracting large amounts of media reports and academic comment. The destroyers, Luyang I and I/ class missile destroyers, commissioned in 2004 and 2005 respectively, were some of the most modern ships in the Chinese fleet. Both ships are armed with a range of anti-ship and anti-air missiles, and the Luyang // class also has the capability to launch land-attack cruise missiles. As warships, they were more than capable of fending off Somali-pirates with rocket propelled grenades and assault rifles. Another constant magnet for attention to the Chinese Navy is the ex-Soviet aircraft carrier Varyag, which began undertaking sea trials in 2011 and finally entered service in 2012 as the Liaoning. This Admiral Kuznetsov class ship has been in extended refit since it was acquired by the Chinese Navy in 2005, requiring the instillation of weapons systems, electronics, and (according to some sources) engines. The only other ship of the class currently in service belongs to the Russian Navy. It is the Fleet Admiral of the Soviet Union Kuznetsov (abbreviated to Admiral Kuznetsov) and is capable of carrying 28 modern fighter aircraft, along with helicopters to support operations. Without context, these ships and the deployment to Somalia would indicate that the PLAN is developing into a modern, highly capable navy with the ability to operate relatively well out of China's immediate area.

This is however a flawed picture of Chinese maritime strategy and the PLAN, based largely on the assumptions of offensive realism. This research paper seeks a fuller understanding of Chinese maritime strategy based on the development of China's maritime forces and their recent operations. It also seeks to determine whether these developments adhere to the expectations of defensive realism. By examining the history and current state of the PLAN, we can see that historically it has been orientated in defence of territory that China considers its own and remains so. Furthermore, it is a force that is in need of its current modernisation programme. By also looking at the recent operations of the PLAN and China's paramilitary organisations, we gain a valuable insight into the shape of China's maritime strategy, particularly in regard to the territorial disputes that China is currently engaged in. These two areas will allow us to gain a clear perspective on China's maritime strategy, showing it to be orientated towards pursuing security rather than power. 
This research paper is focused on China's maritime strategy and in doing so attempts to avoid a US-centric view of the competition, or overly focusing on US or other views of legitimacy in territorial disputes. Much of the literature on China's rise is focused on the US reaction, particularly with the rebalancing towards Asia currently underway. Such a focus often ignores key facts on China's rise, something this paper seeks to correct. This focus on Chinese strategy is also important in ensuring that China's perceptions, as well as its actions, are taken into account. The key example of this is in the South China Sea, China believes it has a legitimate claim to the area, and whether or not this claim is viewed by others as legitimate is immaterial to Chinese strategy.

The growth and modernisation of the Chinese navy is a fact of life that states in the region will have to live with. How they choose to do this will be important, particularly in regards to the territorial disputes that China is involved with. The development of the PLAN is part of a Chinese quest for security, one that is in line with defensive realist expectations of Chinese strategy and actions. The development of the Chinese maritime forces is intended to defend areas that the Chinese government considers its territory, such as the South China Sea and Taiwan, thus ensuring security for the state. Meanwhile, the PLAN also conducts anti-piracy operations and humanitarian evacuation in order to develop the PLAN and demonstrate to domestic audiences that the Chinese military is as world class as the propaganda claims, and that it is prepared to guard China's interests which now span the world. This Chinese strategy is in lines with the expectations of defensive realism and shows it to be a more useful theory for the analysis of the international dynamics at play in Asia than offensive realism.

In order to achieve the goals of this paper it will begin with a review of the current literature on the PLAN and its development, as well as Chinese naval policy overall. This will be undertaken to both identify weaknesses in the current literature on the Chinese Navy, as well as to bring readers up to speed on the current state of the debate. The literature review will also address the current theoretical perspectives that dominate the debate on China and how these play into the different narratives portrayed in the literature. This review will also look at the international relations theories which are brought to bear and to clearly present the theory of defensive realism, which will be used to analyse Chinese actions in the maritime realm.

The second chapter will overview the history of the PLAN since its foundation in 1950, up to the beginning of the modern period in its development, signalled by the end of the Taiwan Straits crisis in 1996. This will look at the maritime history of China prior to the PRC, the broad strategy of the PLAN and the priority it received in the PLAs funding. This will serve to give context to the 
DEFENSIVE REALISM AND CHINESE MARITIME STRATEGY

modernisation that the PLAN has undergone in the past two decades and establish the constraints that are still present on the PLAN due to its history. It will also show a historical focus on maintaining security for the Chinese state against a variety of threats.

The third chapter will look specifically at the current modernisation of the PLAN. This will begin by discussing the motivations behind the modernisation of the PLAN. This section will then look at the sources of Chinese naval platforms and technology, both foreign and domestic. The composition of the current Chinese fleet and the new platforms and capabilities that the PLAN is developing will be discussed, as well as efforts to enhance the professionalism of the service and the level of knowledge in its sailors and officers. China's future aircraft carriers will be examined, as well as the expansion of China's paramilitary maritime organisations. The development of the Chinese navy will also be compared to two other naval forces in the region, Japan and Vietnam, so as to put China's expansion in some context. From this we can see that the Chinese navy is in need of modernisation if it is to replace its aging and obsolete fleet that can be a danger to those serving aboard.

Chapter four will look at the recent operations and exercises undertaken by the Chinese navy, particularly the missions undertaken off the coast of Somalia combating piracy starting in 2008 and the dispatch of a warship to assist in the evacuation of Chinese nationals from Libya in early 2011. Of particular interest for the analysis of the PLAN are the motivations of the Chinese government for undertaking these deployments, the conduct of them, any shortcomings in PLAN capacity identified, the results of interactions with other states and institutions, and what lessons or intelligence the Chinese gain from the missions. The operations off the coasts of Somalia and Libya are not indicative of a new global military role for the PLAN, rather any out of area operations will be limited to military operations other than war. Recent exercises do show that the PLAN is now able to regularly operate task forces out into the second island chain, a notable increase in its overall capability.

The paper will then look at incidents at sea involving both the PLAN and Chinese paramilitary organisations. These incidents are important as they are reflective of both China's interpretation of the United Nations Convention on the Law of the Sea (UNCLOS) and China's strategy towards disputed territories, such as the South China Sea and Senkaku Islands. In looking at these incidents, we can see a Chinese strategy that is driven by a desire to ensure negations over the future of these regions take place in conditions most favourable to China. These incidents at sea are indicative of a state seeking security and defending its claim to territory. 
The last aspect of Chinese maritime operations and strategy that will be examined is incidents at sea and territorial disputes. These two matters are closely linked, as many of the incidents between Chinese and foreign vessels are carried out in order to reaffirm China's claim to regions such as the South China Sea and the Senkaku Islands. Examining these incidents highlights the expanding role of China's paramilitary maritime organisations and their role in maintaining the claim Chinese jurisdiction, particularly in the South China Sea. The incidents are reflective of both China's interpretation of the United Nations Convention on the Law of the Sea (UNCLOS) and China's strategy towards disputed territories and waterways. In looking at these incidents we can see a Chinese strategy that is driven by a desire to ensure negations over the future of these regions take place in conditions most favourable to China. Incidents at sea between Chinese and foreign vessels are indicative of a security seeking state that is defending its claim to territory.

The paper will then conclude by examining the possibilities for a settlement of the disputes between China and its maritime neighbours. This will include the role that the USA can play in shaping an outcome based on international law rather than bilateral negotiations. It will also comment on how defensive realism can be further developed to improve its usefulness in maritime disputes and security competitions. 


\section{LITERATURE REVIEW}

The current literature on the development of the Chinese navy has two main arguments. The first largely conforms to the 'China Threat' argument, which also includes offensive realist theory. The China Threat school argues that China is developing military, and particularly naval, forces to prevent the US interfering in a conflict in China's maritime environment, possibly over the status of Taiwan. The second school of thought is slightly broader in its arguments but basically states that the Chinese navy is not as grave a threat as it is often presented and is more in line with defensive realist thinking. This is either due to persistent weakness in the PLAN or because the Chinese government does not have hegemonic ambitions. These two positions will be reviewed more extensively in the following section. This literature review will also discuss three predominant theoretical perspectives on international relations, setting out the theory that will be tested against the actions of China, defensive realism.

\section{China Threat}

The first overall argument that will be reviewed is the China threat argument. This argument is developed mostly from offensive realist thinking, primarily of US origin, about the rise of China, seeing China as a rising potential hegemon that will be building a military that is capable of challenging the current dominant power in Asia, the USA. Its origins can be traced to and Richard Bernstein and Ross H. Munro's The Coming Conflict with China. ${ }^{1}$ At times this argument can be quite overstated in tone, this being seen in a piece written by Vitaliy Pradun. ${ }^{2}$ In his article, Pradun outlines developments in Chinese cruise and ballistic missile technology which he believes can be used to prevent an intervention by the US Navy in the event of a war between China and Taiwan. This access denial strategy would involve the use of large numbers of cruise and anti-ship ballistic missiles at long ranges to overwhelm US Navy ships defences and inflict enough damage to prevent their involvement in a conflict. Pradun's view is both extreme and flawed. If a conflict such as the one that Pradun posits were actually to take place, then the US is unlikely to send in its surface ships into the region without first crippling the Chinese military infrastructure that is required to undertake such a strike. Instillations such as over the horizon radar stations, which would be required to target an anti-ship ballistic missile, are large and obvious targets that would

\footnotetext{
${ }^{1}$ Chikako Kawakatsu Ueki, "The Rise Of "China Threat" Arguments" (Massachusetts Institute of Technology, 2009$), 118$ - 19, 63 - 64.

${ }^{2}$ Vitaliy O. Pradun, "From Bottle Rockets to Lightning Bolts: China's Missile Revolution and PLA Strategy against U.S. Military Intervention," Naval War College Review 64, no. 2 (2011).
} 
be slated for attack in the opening stages of a war. ${ }^{3}$ The adaptability of the US military in the face of the Chinese military is a key factor in an article by James Kraska. ${ }^{4}$ Kaska's article, 'How the United States Lost the Naval War of 2015', is similar in tone to Pradun, outlining how China's developing naval and other military capabilities could be used in a future conflict to prevent US forces approaching the Chinese mainland. Unlike Pradun, Kraska also discusses technologies that the US could develop to prevent such an outcome. Kraska stresses that such investment in technology needs to be undertaken by the US military in order to balance against developing Chinese capabilities. These articles are two of the most alarmist in saying that China already has, or is close to having, the capability to prevent the US navy from operating in its region. They represent the height of the China threat argument.

A slightly less alarmist view is presented By Richard Fisher in his 2008 book, China's Military Modernization: Building for Regional and Global Reach. Fisher argues that China is developing power projection capabilities, not only at sea, but also on the land. He uses the example of a recent military exercise held between Russia and China in Central Asia (Peace Mission 2007) characterising it as a dress rehersal for possible intervention in the region to prevent the emergence of democratic governments. Fisher sees the future role of the Chinese Navy as being similar, a force that can project power to distant shores in order to intervene in other countries affairs. Due to this focus on a force based on power projection, Fisher concentrates on three areas of the PLAN; aircraft carriers, aphibious platforms, and non-nuclear cruise missiles in a precision land attack role. ${ }^{5}$ The focus on these three key area has some major flaws. The most glaring being Fishers invention of a new type of aircraft carrier, conventional take off and landing (CTOL). CTOL is a designation given to aircraft, not aircraft carriers. Also important, amphibious and aircraft carrier operations can only be undertaken with control of the surrounding battlespace; above, on, and under the water. This requires the development of a supporting fleet that is capable of dominating all these areas, which in many ways presents as great a challenge as mastering flight operations off an aircraft carrier, but is a requirement that Fisher fails to address. ${ }^{6}$ An interesting point that Fisher raises is the role of nationalism in the modernizing of the Chinese Navy, painting the development of the navy as part of a drive to reverse the humiliation suffered at the hand of

\footnotetext{
${ }^{3}$ Jan van Tol, Airsea Battle: A Point-of-Departure Operational Concept (Washington, D.C.: Center for Strategic and Budgetary Assessments, 2010), 58-60.

4 James Kraska, "How the United States Lost the Naval War of 2015," Orbis 54, no. 1 (2010).

${ }^{5}$ Richard D. Fisher, Jr., China's Military Modernization: Building for Regional and Global Reach (Westport: Praeger Security International, 2008), 174, 83-99.

${ }^{6}$ Nan Li and Christopher Weuve, "China's Aircraft Carrier Ambitions: An Update," Naval War College Review 63, no. 1 (2010): 15 - 17, 20 - 25. 
DEFENSIVE REALISM AND CHINESE MARITIME STRATEGY

foreign powers in the past. ${ }^{7}$ While only briefly addressed in this work, it is a theme addressed to a greater extent by other authors.

The role that nationalism and particularly prestige strategies, strategies used to reinforce the regimes domestic legitimacy, plays in the modernisation of the PLAN is a question that is addressed by Robert Ross. In an artcle on the subject, Ross argues that China's naval modernisation is a suboptimal use of defence dollars, given that China is a continental power ringed by potential adversaries. Rather than being driven by a real strategic need for a powerful navy with a blue water capability, the growth and modernisation of the PLAN is being driven by the demands of Chinese nationalists that see the creation of a powerful navy as a requirement for China to take its place as a great power. He states that China is not reliant on maritime trade to any meaningful degree, and therefore the defence of its sea lanes of communication (SLOC), a common reason given for China's naval modernisation, is not a task that the navy need concern itself with. ${ }^{8}$ Perhaps the most interesting idea put forward in Ross' article is that the modernisation of the PLAN represents not just a threat to China's neighbours or to the stability of Asia, it represents a threat to China itself. By creating tension with the USA, diverting funding from other components of the PLA, and by creating valuable but not well defended targets, the PLAN is more of a hazard than an asset to China and its military. ${ }^{9}$ Ross's assessment drew criticism from Michael Glosny and Phillip Saunders. Glosny and Saunders dispute Ross's claims in the areas of continental threats and the importance of SLOC to the Chinese economy. Whereas Ross sees potential conflict stemming from China's land boarders, Glosny and Saunders state that China's land borders are stable and becoming even more so as China continues to settle border disputes. At the same time as the borders are stabilising, the threats that the PLAN are having to prepare for are increasing. China relies heavily on the import of oil for its transport sector and relies on the import of raw materials and export of finished products, all done by sea, in order to maintain its economic strength. ${ }^{10}$ In response to Ross's argument that the Chinese navy is a threat to Chinese security, the authors also point out that the US fleet is not the only potential adversary of the PLAN, and that while the Chinese fleet may be incapable of winning a conflict with the US, it will be useful to increase:

\footnotetext{
${ }^{7}$ Fisher, China's Military Modernization: Building for Regional and Global Reach, 184.

${ }^{8}$ Robert S. Ross, "China's Naval Nationalism: Sources, Prospects, and the U.S. Response," International Security 34, no. 2 (2009): 46, 55 - 58, 65 - 69.

9 lbid.: 75 - 77.

${ }^{10}$ Michael A. Glosny, Phillip C. Saunders, and Robert S. Ross, "Debating China's Naval Nationalism," International Security 35, no. 2 (2010): 161 - 63.
} 
“China's ability to defend regional interests in contingencies not involving the United States, to protect expanding overseas interests, to perform nontraditional missions, to conduct military diplomacy, to demonstrate international responsibility, and to increase China's prestige."11

These roles for the PLAN, outside of conflict with the current dominant power in the region, are important for understanding and analysing the future trajectory of the Chinese Navy. The ability of nationalist sentiment to influence the development of the navy is also questioned as there is no decision making process within the Chinese government that can be seen to factor in the nationalist sentiment described in Ross's article. Ross counters this claim, pointing out that the lack of transparency in Chinese decision making makes identifying any process virtually impossible. ${ }^{12}$ A December 2011 piece by David Lundquest also suggests that nationalism is a key influence on Chinese foreign policy and strategy. This looks not only at the way in which Chinese policy makers take into account the public's nationalist sentiment, but at the fact that the policy makers themselves have bought into these nationalistic beliefs about China's place in the world. ${ }^{13}$ This debate about the role of nationalism in both Chinese naval policy and general foreign policy is an important part of the literature.

\section{China in Perspective}

The other general argument that is raised in the literature is broadly opposed to the China threat perspective. This literature has a theoretical framework derived from both defensive realism and liberal institutionalism and usually challenges the China threat literature on the basis of factual accuracy, rather than on the offensive realist assumptions and view point. A clear example of this challenge to factual basis is a piece by Daniel Kostecka on ports that can be used for logistical support for PLAN ships on anti-piracy operations in the Gulf of Aden. Kostecka's discussion of the issue stands opposed to the 'string of pearls' thesis which states that China is seeking to build a series of port facilities, and eventually naval bases, across the Indian Ocean. ${ }^{14}$ By simply looking at the bases that have been proposed as part of the 'string of pearls', and the way that the PLAN has actually operated over the previous decades, Kostecka shows that the 'string of pearls' is nonexistent and infeasible. Similarly, Erik Lin-Greenberg discusses the PLAN's deployment of ships to

\footnotetext{
${ }^{11}$ Ibid.: 166 .

12 Ibid.: 165 - 66, 72.

${ }^{13}$ David Lundquist, "Nationalism, History \& Policy," The Diplomat, 18 December 2011, accessed 11 January 2012, http://the-diplomat.com/china-power/2011/12/18/nationalism-history-foreign-policy/.

${ }^{14}$ See Gurpreet S. Khurana, "China's 'String of Pearls' in the Indian Ocean and Its Security Implications," Strategic Analysis 32, no. 1 (2008).
} 
DEFENSIVE REALISM AND CHINESE MARITIME STRATEGY

participate in anti-piracy operations off the coast of Somalia. Lin-Greenberg looks in detail at how the deployment might help develop the PLAN's ability to conduct SLOC protection missions in the event of a major conflict, the Somalia mission being often cited as an example of China preparing for such a task. Lin-Greenberg states that the two mission types, SLOC protection and anti-piracy, are extremely different in the tasks that a navy would have to undertake to complete them successfully. Fending off pirates armed with rocket propelled grenades and Kalashnikovs is entirely different to defending shipping against the attacks of submarines, ships, and aircraft of another state. The author sees the only real training crossovers being in the area of sustaining a blue-water naval operation at a long range from the Chinese mainland, coordinating operations in a multinational environment, and equipment operation skills. He also cast doubt on the idea that the deployment is intended to protect Chinese citizens and economic interests, particularly as the initial period of the mission had PLAN ships only protecting Chinese flagged ships, rather than those with Chinese crews or even those heading to or from Chinese ports. What Lin-Greenberg suggests is that the Somali mission, as well as deployments of troops to UN peace keeping missions in Africa, demonstrates a new willingness in the Chinese government to deploy forces in military operations other than war. These forces act to enhance China's image abroad as a responsible global actor. ${ }^{15}$

Another example of the analysis of Chinese military capabilities is an article by Marshall Beier. Beier believes that the capabilities of the Chinese Navy are being grossly overestimated due to flawed analysis which is similar to what occurred with the Soviet Navy during the Cold War. Examining the Chinese fleet in detail, Beier questions the importance that is often given to the quantity of ships in the Chinese fleet, rather than the quality, which can be abysmal compared to more technologically advanced militaries. The prime example of this is Chinese submarines, the vast number of which are based on 1960s designs and would be of limited use in a conventional conflict. The ability of the Chinese shipbuilding industry is also bought into question as the most advanced Chinese surface combatants are Russian produced Sovremenny class destroyers, reflecting Chinese inability to produce its own modern and effective ships. The possible ongoing effects of the Cultural Revolution on the PLAN are also queried, with the author suggesting it may well have the kind of long term effects that Stalin's purges had on the Soviet Military, creating a

\footnotetext{
${ }^{15}$ Erik Lin-Greenberg, "Dragon Boats: Assessing China's Anti-Piracy Operations in the Gulf of Aden," Defense \& Security Analysis 26, no. 2 (2010): 217 - 18, 23, 26.
} 
force that is far more political than professional. ${ }^{16}$ As well as Beier's main point about the actual capabilities of the PLAN, his article also suggests that the PLAN is in desperate need of modernisation if it is to become a force that can complete even basic military tasks, and in the case of China's submarines, doing so without endangering the lives of the crew. But while Beier has a very thought-provoking thesis which has interesting implications for the study of the PLAN, it is important to note that, while many authors acknowledge that the PLAN has been underfunded for most of its existence, this article is unique in its assertion that both past and present ships of the Chinese fleet are of such a poor quality. Indeed some of the references in the article fail to back up the claims that Beier makes about Chinese warships. In particular, while Beier claims that the Russian Navy has retired many Sovremenny class destroyers from its fleet due to their obsolescence, this is not backed up by Beier's references which only shown that the ships were retired, and not the reasons why. Beier's work therefore is important, not for its analysis of the PLAN itself, but the implication that the Chinese Navy is being over estimated, and the need to have studies that are based on the quality of naval forces rather than on the number of ships in the fleet.

In a broader examination of the drivers of China's foreign policy strategy, Wang Jisi discusses some of the reasons why military competition between China and the USA is not in China's interests, as well as examining how a more cooperative and open foreign policy would be beneficial for China. Wang examines some possible drivers of a grand strategy in Chinese foreign policy. One which is often suggested is focusing on the threat that the USA posses to China and attempting to build China into a global hegemon which can overcome this threat. ${ }^{17}$ This is a strategy which is in line with the predictions of offensive realists, particularly John Mearsheimer who argues that China's ultimate goal is to achieve hegemony in Asia, displacing the US as the regions supreme military power. ${ }^{18}$ While the idea of opposing the US is popular with Chinese print media and websites covering security topics Wang dismisses this as an unrealistic option. This is due to the inevitable harm to China that would result from a strategy based on confrontation with its largest trading partner, and the damage it would do to China's peaceful rise policies. Building China into a hegemon is also a far more ambitious and unrealistic goal than Chinese leaders are prepared to take on. Wang instead argues that Chinese leaders are shaping a foreign policy based on maintaining China's core interests of sovereignty, security, and development. The best method of

\footnotetext{
${ }^{16}$ Marshall J. Beier, "Bear Facts and Dragon Boats: Rethinking the Modernization of Chinese Naval Power," Contemporary Security Policy 26, no. 2 (2005): 298 - 300, 02 - 03.

${ }^{17}$ Wang Jisi, "China's Search for a Grand Strategy: A Rising Great Power Finds Its Way.," Foreign Affairs 90, no. 2 (2011): 71.

18 John Mearsheimer, "China's Unpeaceful Rise," Current History 105, no. 690 (2006).

10
} 
DEFENSIVE REALISM AND CHINESE MARITIME STRATEGY

achieving this is maintaining a peaceful international environment. However, to achieve this China will need to recognise the legitimate concerns of it neighbours caused by the development of its naval forces and try to allay these through greater transparency and participation in institutions that enhance security in the Asia Pacific. Wang also dismisses the suggestion that the South China Sea is now one of China's core interests, similar to Taiwan and Tibet, and that those commentators in China that made this claim were reckless and did so without official approval. ${ }^{19}$

\section{The Influence of Mahan}

The influence of the American naval theorist Alfred Thayer Mahan on the Chinese Navy is a subject that is currently hotly debated by those that study the PLAN. Mahan was an officer of the US Navy who served during the US Civil War, however it was as a naval theorist that he made his mark. Mahan's first work was as a contributor to the history of the naval conduct of the US Civil War. This led to his appointment as a lecturer at the Naval War College in $1884 .^{20}$ Mahan was the first historian to treat naval history as contributing factor in world events, rather than just listing the most important battles. ${ }^{21}$ Shaped by this reading of history through the lens of naval power, Mahan come to believe that strong naval power is essential in order for a state to maintain its strength, and that naval strength was a key determinant in the outcome of wars. ${ }^{22}$ Mahan was particularly interested in the implications for US security of the opening up of the Panama Canal and the strategically important waterway this would create in the Caribbean. ${ }^{23}$ Mahan's studies of history lead to his thesis that:

\footnotetext{
“a state with predominant sea power, including an adequate navy, a maritime-minded population sustained by a large merchant marine, well distributed bases, and control of narrow waterways could dominate world politics through the use of this power to blockade and strangle its rivals." 24
}

\footnotetext{
19 Jisi, "China's Search for a Grand Strategy: A Rising Great Power Finds Its Way.," 71.

${ }^{20}$ Encyclopedia of World Biography: Alfred Thayer Mahan, 2 ed., vol. 10 (Detroit: Gale, 2004).

${ }^{21}$ Rolf Hobson, Imperialism at Sea: Naval Strategic Thought, the Ideology of Sea Power, and the Tirpitz Plan, 18751914 (Boston: Brill Academic Publishers, 2002), 156.

22 Encyclopedia of World Biography: Alfred Thayer Mahan.

${ }^{23}$ Hobson, Imperialism at Sea: Naval Strategic Thought, the Ideology of Sea Power, and the Tirpitz Plan, 1875-1914, 166.

${ }^{24}$ Greg Russell, "Alfred Thayer Mahan and American Geopolitics: The Conservatism and Realism of an Imperialist," Geopolitics 11, no. 1 (2006): 126.
} 
Mahan's work influenced US expansionists, such as Theodore Roosevelt and Henry Cabot Lodge, who sought to push US influence outside its continental bounds. ${ }^{25}$ Even with this basic reading of Mahan, you can see how his work could be relevant to the current development of the PLAN.

Liu Huaquing, the father of the modern Chinese Navy, is portrayed by some authors as being heavily influenced by Mahan, while others see Admiral Sergey Gorshkov as a foundational thinker for Liu's own work in the PLAN. Gorshkov is said to have taught Liu while he studied at the Voroshilov Naval Academy in the Soviet Union from 1954 to $1958 .{ }^{26}$ In his article on the evolution of Chinese maritime doctrine, Ji You points to this influence on Liu's strategic thinking and states that the PLAN followed similar steps under Liu that the Soviet Navy did under Goshkov. ${ }^{27}$ However, in a similar article by Nan Li, the influence of Gorshkov is questioned. Nan points out that Liu's memoir makes no mention of taking any courses with Gorshknov, as well as stating that he had great difficulties at the naval academy because he had no training in Russian. Furthermore, Liu's memoir highlights the works of Mahan rather than Gorshkov. ${ }^{28}$ Bernard Cole points out the strong influence of Mahan on both Liu and Gorshkov, perhaps rendering the argument moot. ${ }^{29}$

Currently the leading proponents of a Mahanian influence on the PLAN are James R. Holmes and Toshi Yoshihara. Holmes and Yoshihara put a caveat on the application of Mahan's thinking by Chinese leadership. Rather than taking their strategy directly from Mahan, these scholars talk

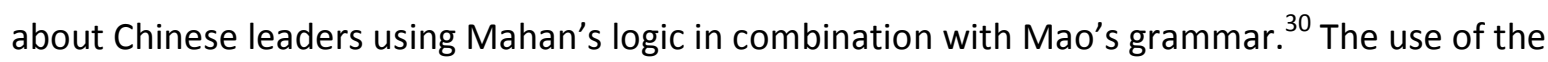
term grammar in this context is taken from the work of Carl von Clausewitz, and was used by the Prussian master to describe the differentiation between peacetime and wartime interaction between states. Holmes and Yoshihara's conception of grammar in naval operations concerns fleet operations, thus negating the fact that Mahan was writing for a battleship navy, and so, operationally and tactically, his writings are outdated. ${ }^{31}$ So how is Mahan influencing the PLAN and Chinese naval thinkers? While Mahan is most often associated with world spanning sea power, such as that possessed by the USA, Chinese readers of Mahan are using it for more limited goals

\footnotetext{
${ }^{25}$ Walter LaFeber, "A Note on The "Mercantilistic Imperialism" Of Alfred Thayer Mahan," The Mississippi Valley Historical Review 48, no. 4 (1962): 674.

${ }^{26}$ Ian Storey and You Ji, "China's Aircraft Carrier Ambitions: Seeking Truth from Rumours," Air Power Journal 1, no. 2 (2004): 126.

27 Ji You, "The Evolution of China's Maritime Combat Doctrines and Models : 1949-2001," RSIS Working Papers 02 , no. 22 (2002): 6-7.

${ }^{28}$ Nan Li, "The Evolution of China's Naval Strategy and Capabilities: From "near Coast" and "near Seas" to "Far Seas", Asian Security 5, no. 2 (2009).

${ }^{29}$ Bernard D. Cole, The Great Wall at Sea, 2nd ed. (Annapolis: Naval Institute Press, 2010), 178.

30 James Holmes and Toshi Yoshihara, "Mao Zedong, Meet Alfred Thayer Mahan: Strategic Theory and Chinese Sea Power," Australian Defence Force Journal, no. 171 (2006): 36.

31 James R. Holmes and Toshi Yoshihara, "Authors' Response: Varieties of Mahanian Experience," Asia Policy 12(2011): 161. 
DEFENSIVE REALISM AND CHINESE MARITIME STRATEGY

which are still in line with Mahan's strategies. Mahan stated that a strong navy is needed to defend a states merchant marine. The ability for the US Navy to cut off Chinese SLOC is a particular concern here and so following Mahan's strategy the PLAN must be expanded so it can protect this merchant traffic. ${ }^{32}$ The second Mahanian goal of the PLAN is to gain sea control, a limited goal that Holmes and Yoshihara draw from Mahan's strategy proposed in 1890 that the US build a navy capable of guarding the approaches to the Panama Canal against all comers. ${ }^{33}$ In the context of the modern Chinese navy, this means keeping an enemy fleet from operating within what is termed the first island chain. Sea denial capability based on modernised surface, missile, air, and submarine forces, as well as efforts to deny the US air dominance, would help to achieve this. ${ }^{34}$ The Maoist grammar comes into sea denial through the use of the Chinese continent and the depth it offers to launch aircraft and missiles to harass an enemy fleet drawn close to the mainland. Not only can offensive capabilities hide in this expanse, but strikes by an opposing state on the Chinese mainland to blunt these capabilities may present an unwanted escalation of a conflict for an enemy that has more limited goals. This would be combined with attacks by surface and subsurface combatants using exterior lines to hit the enemy from multiple directions. ${ }^{35}$ In this way Holmes and Yoshihara put forward a case for the influence of Mahan in the PLAN.

Holmes and Yoshihara's thesis is of course not without its critics, and these come into two broad categories. The first criticism is that the sources of Chinese military strategy are not known due to the lack of transparency within the Chinese government. In a critique of Holmes and Yoshihara work, Zheng Wang focuses on the sources that the two scholars use to come to their conclusions about Chinese naval strategy. Zheng states that many of the sources used are in fact popular commercial magazines written to satisfy demand from Chinese naval aficionados. Those writing articles for these magazines have no special access to inside information and they are written towards a nationalistic audience already supportive of the PLAN. This audience views naval power as a way to prevent a reoccurrence of past national humiliation. Zheng points out that there is a lack of transparency in Chinese military affairs that make assessing sources of Chinese strategy exceedingly difficult, but turning to non-government sources within China will not overcome it. ${ }^{36}$ The second criticism asks to what extent Mahan's strategy actually matters to Chinese policy. Michael McDevitt questions Holmes and Yoshihara for their tendency to see the influence of

32 _- - "The Influence of Mahan Upon China's Maritime Strategy," Comparative Strategy 24, no. 1 (2005): $24-25$.

${ }^{33}$ Holmes and Yoshihara, "Authors' Response: Varieties of Mahanian Experience," 163.

34 - - , "Mao Zedong, Meet Alfred Thayer Mahan: Strategic Theory and Chinese Sea Power," 39-40.

35 James R. Holmes, "China's Way of Naval War: Mahan's Logic, Mao's Grammar," Comparative Strategy 28, no. 3 (2009): 229-31.

${ }^{36}$ Zheng Wang, "Understanding China's Military Strategy: The Challenge to Researchers," Asia Policy 12(2011): $158-60$. 
Mahan in every work that Chinese authors produce about the PLAN. He makes the point that the current Chinese strategy could be arrived at without reference to the works of Mahan. ${ }^{37}$ This is perhaps the other extreme to Holmes and Yoshihara. It is certain that Mahan is having an influence on Chinese naval thinkers, and therefore Chinese naval strategy, but this could be simply through his role as the first historian to bring attention to the role of sea power in history rather than as a naval strategist. The question becomes a matter of degrees; are Mahan and Mao the only influences on Chinese naval thinking? Undoubtedly the answer is no. So while there is a role for the discussion of Mahan in almost all discussions of naval strategy, it is not necessary that he always take the lead. Bernard Cole talks about the influence of Mahan on Chinese strategy more in line with this view of contributing, but not dominant contributor. Cole includes Mahan in a list of other influential naval thinkers, including Wayne Hughes, Julian Corbett, Sergei Gorshkov, Colin Grey, and the PLAN's own Liu Huaqing, all of whose works are widely studied in all navies including the Chinese. ${ }^{38}$

\section{Theoretical approaches}

There are three major theories of international relations that are the most often brought to bear on the maritime strategy of China and the operations of the PLAN. These are neo-liberalism, offensive realism, and defensive realism. Each of these theories makes quite distinct predictions about the shape of Chinese policy and what would be the optimal use of its resources. This section will first address why the theory of neo-liberalism, and particularly liberal institutionalism, is unhelpful for this study. It will then turn to the ongoing debate between offensive and defensive realism, and then the debate within defensive realism. This internal debate centres on issues including the importance of offence-defence balance, the role of balancing and bandwagoning, and the relative influence of economic and military power. This section will identify why defensive realism is the most useful theory for the case study of the PLAN and establish what defensive realism is.

The first theory to be addressed here is neo-liberalism. This theory shares some of the same underlying assumptions as both offensive and defensive realism, particularly the centrality of states acting in their own self-interest. However, it also sees a greater role for cooperation between states. ${ }^{39}$ Cooperation is often conducted within international regimes or institutions within which states gain greater benefits for themselves than through individual action due to

\footnotetext{
${ }^{37}$ Michael McDevitt, "Is the PLA Navy Channeling Mahan? And Does It Matter?," Asia Policy 12(2011): 149 - 50.

${ }^{38}$ Cole, The Great Wall at Sea, 169.

${ }^{39}$ Andrew Heywood, Global Politics (New York: Palgrave Macmillan, 2011), 54 - 55, 61 - 62.
} 
DEFENSIVE REALISM AND CHINESE MARITIME STRATEGY

reduced uncertainty. Regimes and institutions decrease uncertainty by creating legal liability, reducing transaction costs, and enhancing transparency. Due to the high cost of establishing regimes, states are reluctant to leave or start over, and even sub-optimal regimes are more beneficial to states than an unmitigated self-help environment. ${ }^{40}$ The particular problem with the use of this theory, in the case of China's maritime strategy and the operations of the PLAN, is that China has specifically refused to engage in multilateral discussions on maritime territorial issues. Chinese Foreign Minister Yang Jiechi stated clearly during the Association of South East Asian Nations (ASEAN) Regional Forum (ARF) in 2010 that China wished to conduct negotiations bilaterally, without the involvement of third parties (particularly the USA). ${ }^{41}$ Even when China has engaged in multilateral agreements, such as the 'Declaration on the Conduct of Parties in the South China Sea', which was signed between China and the ASEAN states in 2002, its subsequent actions in the region have contradicted the spirit of this agreement. ${ }^{42}$ In a recent article Gilbert Rozman paints a picture of an increasingly belligerent China that is only interested in multilateralism that advances its economic interests. Otherwise, China seeks bilateral negotiations that get the greatest leverage from its position as the regions dominant state. ${ }^{43}$ As China refuses to engage in multilateral institutions or negotiations on security matters, then neo-liberalism's usefulness in this case is extremely limited.

The next issue to address is the debate that is ongoing between defensive and offensive realist theory. These two theories share many assumptions on the nature of international relations but differ fundamentally on how these shape the outcomes of the international politics. The centrality of the state and its propensity to pursue its own self-interest are central to both theories, with this self interest particularly centred on the security of the state itself, the state always being concerned about its own survival. ${ }^{44}$ For offensive realists, this concern with survival leads states to pursue power, primarily military power. The ultimate goal for a state in an offensive realist system is to be the preponderant military and economic power in its region, a hegemon, with the ability to block the emergence of a hegemon in any other region. John Mearsheimer, a leading offensive realist scholar, points to the USA as being a prime example of a hegemon. The USA is the

\footnotetext{
${ }^{40}$ Shaun Narine, "Institutional Theory and Southeast Asia: The Case of Asean," World Affairs 161, no. 1 (1998): $37-38$.

${ }^{41}$ Ying Wang, "China Tells U.S. Not to Internationalize South China Sea Issue," Bloomberg, July 25 2010, accessed 21 July 2011, http://www.businessweek.com/news/2010-07-25/china-tells-u-s-not-to-internationalize-south-china-seaissue.html.

${ }^{42}$ Peter Dutton, "An Assessment of the Effectiveness of Current Maritime Security Frameworks and Mechanisms in the South China Sea" (paper presented at the The South China Sea Reader, Manila, Philippines, 2011), 180 - 81.

${ }^{43}$ Gilbert Rozman, "Chinese Strategic Thinking on Multilateral Regional Security in Northeast Asia," Orbis 55, no. 2 (2011): 311.

${ }^{44}$ Stephen G. Brooks, "Dueling Realisms," International Organization 51, no. 3 (1997): 446.
} 
preeminent military and economic power in its region, and since World War II it has used its military power outside of its own region to prevent other powers from establishing hegemony in other regions, such as during the Cold War when US forces in Europe and Asia ensured another hegemon could not emerge in those regions. ${ }^{45}$ Defensive realism sees a role for power in international relation but it is a means of achieving that which defensive realists argue is the ultimate goal of states; security. ${ }^{46}$ Security is the primary goal of the state, as without it states cannot attain higher goals such as profit and development. ${ }^{47}$ In contrast to offensive realism, defensive realists envisage circumstances in which an increase in military power would result in a decrease in the security of the state, and thus a state acting to maximise its security may not seek an increase in military power. Therefore, a rising power may forgo an expansion of its military power if such an action would cause an arms race by other states and damage the security of the state as other states build up forces and ally to balance against it. ${ }^{48}$

The basic divergence in the ultimate goal of the state gives the theories divergent views of the optimal strategies for states to undertake, as well as the likelihood of conflict in the international system. Offensive realists believe that states must always seek power and that this will eventually lead to conflict. They state that a rising power will always cause conflict between itself and an existing hegemon as both seek a preponderance of power. It is therefore in the hegemon's interests to oppose the economic and military development of potential rivals, and to build coalitions within the challengers region in order to balance against the threat of the rising power. These strategies will ensure that the existing hegemon can retain its pre-eminence, but there is no way to prevent some form of conflict between a rising and an existing power. ${ }^{49}$ The outcomes predicted by defensive realism and the optimal strategies that it suggests are less clear cut. Defensive realism seeks to account for a greater number of variables than offensive realism, including offence-defence balance, security dilemma, domestically generated constraints on foreign policy, and leader's perceptions of other states and their intentions. ${ }^{50}$ This at once makes defensive realism a more nuanced study of international affairs and also leads to criticism that the

\footnotetext{
${ }^{45}$ John Mearsheimer, The Tragedy of Great Power Politics (New York: W. W. Norton \& Company, 2001), 33 - 35.

${ }^{46}$ Kenneth N. Waltz, Theory of International Politics (Reading MA: Addison-Wesley Publishing, 1979), 126.

${ }^{47}$ Randall L. Schweller, "Bandwagoning for Profit: Bringing the Revisionist State Back In," International Security 19, no. 1 (1994): $85-86$.

${ }^{48}$ Brian C. Schmidt, "Realism as Tragedy," Review of International Studies 30, no. 3 (2004): 435.

${ }^{49}$ Mearsheimer, "China's Unpeaceful Rise," 160 - 63.

50 Jeffrey W. Taliaferro, "Security Seeking under Anarchy: Defensive Realism Revisited," International Security 25, no. 3 (2000): 134 - 43. 
DEFENSIVE REALISM AND CHINESE MARITIME STRATEGY

scope of the theory makes it unfalsifiable and unuseful. ${ }^{51}$ One of the key tenants of defensive realism is the intractability of the security dilemma, that is that the actions of one state to make itself more secure can result in another state feeling less secure and leading to the second state taking actions to remedy this through the development of its own strength. ${ }^{52}$ This system feeds on itself, and as militaries expand and mistrust grows between the states, so does the risk of miscalculation and war as one state may feel the need to strike first to defend against the perceived threat of its competing states. States, particularly strong states, are therefore best served by communicating restraint through their actions so that other states do not feel their security is threatened. ${ }^{53}$ Because states seek security rather than power, there is no end game that all states are working towards, as opposed to offensive realisms drive to hegemony.

Both theories have come under criticism, particularly from authors of the competing theory. John A. Vasquez described the work of Kenneth Waltz and defensive realism as a degenerative research programme based on what he saw as a lack of evidence to support the theories conclusions. ${ }^{54}$ Richard Rosecrance states that defensive theory is largely unfalsifiable and "unhelpful theoretically and empirically". However, in what is a more telling statement, he also describes offensive realism as eminently falsifiable, but also demonstrably false. ${ }^{55}$ Others criticise offensive realist theory for its assertion that states will gain power, and therefore come closer to achieving hegemony through conflict. A study by Brandon Valeriano shows that only fourteen percent of great power conflicts actually end in victory for the great power. Disputes and conflict cannot therefore be exploited to gain power as readily as offensive realism claims. ${ }^{56}$ Another criticism of offensive realism is its overwhelming focus on power and great powers, usually the USA. This focus on power ignores areas that are clearly of great importance in a state's foreign policy. ${ }^{57}$ Matthew Rendall also accuses Mearsheimer of selection bias in his seminal work on offensive realism, The Tragedy of Great Power Politics. Rendall states that Mearsheimer's work focuses on aggressive states during historically aggressive periods, and ignores states that had the potential to become militarily great powers but forgo the option. This leads to conclusions that overstate the frequency

\footnotetext{
${ }^{51}$ Richard Rosecrance, "Power and International Relations: The Rise of China and Its Effects," International Studies Perspectives 7, no. 1 (2006): 31.

${ }^{52}$ Taliaferro, "Security Seeking under Anarchy: Defensive Realism Revisited," 136.

53 Ibid.: 129.

54 John A. Vasquez, "The Realist Paradigm and Degenerative Versus Progressive Research Programs: An Appraisal of Neotraditional Research on Waltz's Balancing Proposition," The American Political Science Review 91, no. 4 (1997).

${ }^{55}$ Rosecrance, "Power and International Relations: The Rise of China and Its Effects," 31.

${ }^{56}$ Brandon Valeriano, "The Tragedy of Offensive Realism: Testing Aggressive Power Politics Models," International Interactions 35, no. 2 (2009): 200.

${ }^{57}$ Andrew Hurrell, "Hegemony, Liberalism and Global Order: What Space for Would-Be Great Powers?," International Affairs 82, no. 1 (2006): 6.
} 
of high risk, high cost aggression by states in pursuit of hegemony. ${ }^{58}$ While offensive realism is satisfied with its explanation of the competition for power, several defensive realist authors have sought to address the criticisms levelled at their area of study, seeking to clarify their position. This work allows for an examination of Chinese maritime policy that can explain both the growth and restraint in Chinese maritime forces, and which has the possibility of outcomes other than the conflict offered by offensive realism. The need for theoretical explanations other than offensive realism is further heightened by the role of nuclear weapons, which have made the risks associated of great power wars hopelessly high. The next section of this chapter will look at defensive realism and its current debates so that the expectations of the theory are made clear.

Defensive realism was originally proposed by Kenneth Waltz, and looks at the international system itself as the predominant influence on state behaviour. This focus on structure was a counter argument to the classical realism of authors such as Hans Morgenthau that explained state behaviour as an extension of a human desire to dominate others through violence, a desire that states fulfil through war. ${ }^{59}$ Instead, defensive realism finds the motivation of states in the structure of the international system, rather in any inherent human motivation. The international system is one of anarchy, in which there is no higher power than the state. States do not have another body to guarantee their safety and so they must ensure their own security. ${ }^{60}$ Defensive realism still holds that states are self interested, however states will only seek to expand in certain conditions. States that do not meet these conditions may still try to undertake expansion, however this is often due the leader of a state believing that aggression is the only method to make their state secure. ${ }^{61}$ In a situation in which a country cannot guarantee its own security it may cooperate with other states in order to achieve this. ${ }^{62}$ The likelihood of this occurring, and who a state allies with, is a significant debate within defensive realism itself.

In his original theory of defensive realism, Waltz stated that a state has two options when its security is threatened by another state: it will either balance or bandwagon. Within Waltz's conception, to balance was to join a weaker coalition to oppose a stronger power. ${ }^{63}$ The other option a state has is to bandwagon with the aggressive state, to join with them in order that the

\footnotetext{
${ }^{58}$ Matthew Rendall, "Defensive Realism and the Concert of Europe," Review of International Studies 32, no. 3 (2006): $525-26$.

${ }^{59}$ Stephen M. Walt, "International Relations: One World, Many Theories," Foreign Policy, no. 110 (1998): 31.

${ }^{60}$ Heywood, Global Politics, 455 - 56.

${ }^{61}$ Taliaferro, "Security Seeking under Anarchy: Defensive Realism Revisited," 129.

62 Denny Roy, "Southeast Asia and China: Balancing or Bandwagoning?," Contemporary Southeast Asia 27, no. 2 (2005): 306.

${ }^{63}$ Waltz, Theory of International Politics, 126. 
DEFENSIVE REALISM AND CHINESE MARITIME STRATEGY

state will avoid the harsher treatment which would be meted out against an opposing state. Such bandwagoning is at the cost of the weaker state, having to give up autonomy, and accepting domination. ${ }^{64}$ States then have two options when faced with an aggressive state; to be with them or against them. This perspective on balancing and bandwagoning has been questioned by authors subsequently. An article by Randall L. Schweller questions Waltz's vision of bandwagoning, arguing that Waltz puts the bandwagoning at the opposite end of the spectrum from balancing, being an option in similar to capitulation in that states essentially surrender to an aggressor. Schweller states that there can be both positive and negative inducements to undertake bandwagoning behaviour, including sharing the spoils of victory and economic inducements. He also argues that balancing is almost always a more costly behaviour than bandwagoning. This leads Schweller to the conclusion that the instances of balancing in the international system have likely been over stated by authors such as Walt and Waltz, and that states will bandwagon for profit or where their interests ally with the aggressor state. ${ }^{65}$ Schweller's work on balancing and bandwagoning adds more options to the analysis of this behaviour, removing the simple fight or fall dichotomy that had existed in the literature. However, the propensity of states to bandwagon based on economic inducements has also been challenged by authors.

Robert S. Ross produced an article which sought to challenge the assertion that secondary states will bandwagon with great powers that have a preponderance of economic force, rather than military force. This plays into the work of Schweller, examining what conditions are likely to generate balancing or bandwagoning behaviour in states. It was Robert L. Rothstein who posited that secondary states, those that are on the tier below great powers, will align themselves based on their individual circumstances and local balance. ${ }^{66}$ This can include a function for the economic influence of great powers, as well as military capabilities. ${ }^{67}$ Ross tests this theory using the case study of Asia and the reaction of regional secondary powers to the rise of Chinese economic and military powers. Ross finds that perceptions and responses to Chinese power by secondary states are moderated by geographical proximity. States that are close enough to China to be threatened by China's developing military power (Vietnam, Burma, South Korea, and also Taiwan) will accommodate China's interests and will not act to balance against China. Those further from China and less threatened by its military development are more likely to balance against China's growing

\footnotetext{
${ }^{64}$ Stephen M. Walt, "Alliance Formation and the Balance of World Power," International Security 9, no. 4 (1985): 7 - 8.

${ }^{65}$ Schweller, "Bandwagoning for Profit: Bringing the Revisionist State Back In," 85, 93, 99.

${ }^{66}$ Robert S. Ross, "Balance of Power Politics and the Rise of China: Accommodation and Balancing in East Asia," Security Studies 15, no. 3 (2006): 362.

${ }^{67}$ Rawi Abdelal and Jonathan Kirshner, "Strategy, Economic Relations, and the Definition of National Interests," Security Studies 9, no. 1-2 (1999): 119 - 22.
} 
capabilities. Ross uses the example of Japan and Singapore, states that are both balancing against China and increasing cooperation with the US, despite having respectively negative and positive views of China's intentions in the region. The influence of economics on the actions of secondary states is therefore minimal compared to the combination of military strength and proximity of a great power. ${ }^{68}$ Ross' article also confirms one of Schweller's basic conclusions from his work on balancing and bandwagoning, that balancing is less common than is asserted by some defensive realist scholars. ${ }^{69}$ Ross' article was published in 2006 during a period in which China's military policy and diplomatic efforts in the region where less bellicose than they are now and may no longer reflect the situation in Asia. As will be shown later in this paper, the position of some states, particularly Vietnam, the Philippines, and Burma, have now changed and active balancing against Chinese capabilities can now be seen. The most important lesson from Ross' article is that the attractiveness of China's economic success counts for less with states than its growth in military power.

Offence-defence balance is another area important to defensive realism that has been subject to significant debate. Offence-defence balance, originally set out by Robert Jervis, seeks to measure whether military technology favours a state on the offence or defence. In an era in which offensive technology has the advantage, then it is easier for states to take territory than defend what they have. This creates an incentive for states to attack threatening neighbours in order to guarantee their own security. Conversely, when defensive technology predominates, then states can easily hold what they own and it is very costly to take territory, therefore war is unlikely. ${ }^{70}$ However, there is a major issue with offence-defence balance and its ability to be usefully applied to this research topic, being that it focuses predominantly on land combat. An article by Steven Biddle states the naval conflicts are beyond the scope of the theory, but argues that the vast majority of conflicts are continental (land based) and therefore this is not a major issue for the theory. ${ }^{71}$ For this research topic it clearly is an issue. However, there are some aspects of offence-defence balance that can be applied to a naval conflict, primarily that distance favours defence. The greater the distance an attacker is from the defender the greater the advantage for the defender, as the costs and difficulty of logistics increases. ${ }^{72}$ In other respects, combat at sea does not have a defensive element in that both sides are trying to destroy the opposing force on essentially neutral

\footnotetext{
${ }^{68}$ Ross, "Balance of Power Politics and the Rise of China: Accommodation and Balancing in East Asia," 392 - 95.

${ }^{69}$ Ibid.: 394 - 95.

${ }^{70}$ Charles L. Glaser and Chaim Kaufmann, "What Is the Offense-Defense Balance and Can We Measure It?," International Security 22, no. 4 (1998): 47 - 49.

${ }^{71}$ Stephen Biddle, "Rebuilding the Foundations of Offense-Defense Theory," Journal of Politics 63, no. 3 (2001): 756.

${ }^{72}$ Glaser and Kaufmann, "What Is the Offense-Defense Balance and Can We Measure It?," 65.
} 
DEFENSIVE REALISM AND CHINESE MARITIME STRATEGY

terrain, making both sides essentially offensive. The compact geographic nature of the contested space in Asia, particularly those areas with territorial disputes, further limits any differences based on distance. Even the US has bases in the region that serve to limit the effects of distance on US forces. Therefore, with this papers focus on naval strategy and forces, the offence-defence balance is not a useful concept at present. In the future, and with the increasing importance of maritime Asia in both defence planning and international relations research, maritime aspects will need to be integrated into this concept to keep it relevant.

The last facet of defensive realism that is important to understand is the security dilemma and how this effects the actions of states. The security dilemma is one of the cornerstones of defensive realism, thought the concept is also utilised in different ways by offensive realists and neoliberal scholars. ${ }^{73}$ While a basic overview of security dilemma was given earlier in this chapter, the concept will be developed in detail in this section, examining the key components of the concept. The term 'security dilemma' was coined by John Herz, and was used to describe how within the anarchic international system states would take steps to protect themselves from the threat posed by another state by acquiring additional military capacity, capacity which would then cause other states to feel threatened. In this cycle, even states that sought peace would be dragged into a cyclic struggle for power which threatened arms races and war. ${ }^{74}$ From the analysis of security dilemma definitions, Shiping Tang identifies eight key aspects of security dilemma: its source is the anarchic nature of the international system; this anarchy creates uncertainty about intentions, creating fear between states; it is unintentional; as a defence against uncertain intentions, states accumulate power to protect themselves, which will invariably contain some offensive capability; the security dilemma is self-reinforcing and can lead to spirals of deteriorating relationships; accumulating such power can be self-defeating, with additional power resulting in less security; it can result in a vicious cycle causing unnecessary wars; it can be reduced by both material and psychological factors. ${ }^{75}$ Material factors which influence security dilemma include geographic proximity, the regional military balance, offence-defence balance, and the level of difficulty in extracting resources from captured territory. ${ }^{76}$ Historical mistrust between states, misperceptions, and ethnocentrism are examples of psychological factors. ${ }^{77}$ The causes and consequences of the

\footnotetext{
73 Shiping Tang, "The Security Dilemma: A Conceptual Analysis," Security Studies 18, no. 3 (2009): 588.

${ }^{74}$ Christoph Bluth, "The Security Dilemma Revisited: A Paradigm for International Security in the Twenty-First Century?," The International Journal of Human Rights 15, no. 8 (2011): 1362.

${ }^{75}$ Tang, "The Security Dilemma: A Conceptual Analysis," 594 - 95.

${ }^{76}$ Taliaferro, "Security Seeking under Anarchy: Defensive Realism Revisited," 137.

77 Thomas J. Christensen, "China, the U.S.-Japan Alliance, and the Security Dilemma in East Asia," International Security 23, no. 4 (1999): 50; Tang, "The Security Dilemma: A Conceptual Analysis," 604.
} 
security dilemma are an important part of defensive realism and vital for understanding the theory.

This paper intends to further develop the use of defensive realism as the key theoretical perspective to examine the operations of the Chinese Navy, as well as China's maritime strategy. Understanding the key concepts of defensive realism will allow this paper to both test Chinese actions against the theoretical expectations, as well as identifying short falls is the literature. As can already be seen in the discussion of the offence-defence balance, there are some areas of the theory that are as yet not readily applicable to this topic. Defensive realism is nonetheless a robust, well debated and developed theory of the interactions between states. However, it has yet to be appled to the case of Chinese maritime strategy, and this is the area in which this research paper will contribute most to the existing literature. Throughout this paper it will be shown that Chinese maritime strategy is in line with a state that has, as its highest goal, its own security rather than the power, as argued by offensive realists. It will also show how there is a developing arms race in Asia as a result of both China's quest for security and a security dilemma which has spread from it. In the end it is my hope that the evidence presented in this paper both proves the tenets of defensive realism, and by doing so help to disprove one of the central arguments put forward by offensive realists: that China has, at the centre of its maritime strategy, the goal of becoming the hegemonic power in Asia. 


\section{A HISTORY OF THE PLAN}

The PLAN lacks the centuries of operational experience present in most navies around the world. Created in 1949, and formally established in 1950 during the final phase of the Chinese Civil War, the PLAN has, for almost its entire history been a secondary priority to the PLA, with ground forces coming first. The role of the PLAN has changed greatly since its creation 60 years ago, and its strategy has evolved to fit the major threats to the security of the Chinese state. An understanding of the evolution of the PLAN, including its perceived importance in the defence of China, the level of funding it has received, and the strategy it has undertaken, are vital to understanding the current path of the navy of the People's Republic. This history shows that the PLAN has undertaken a development pragmatically based on the security needs of the People's Republic.

\section{China's Maritime Heritage}

China is not without a maritime tradition, with the voyages of Zheng He being the favoured example of China's previous maritime supremacy. The voyages of his treasure fleets marked the end of a five hundred year period, spanning from the $10^{\text {th }}$ to $15^{\text {th }}$ centuries, in which the Middle Kingdom's navy was both quantitatively and qualitatively superior to any other on earth. ${ }^{78}$ During his Voyages, Zheng He visited as far away as modern day Yemen and Somalia, as well as a great many areas in Asia. ${ }^{79}$ Following these voyages, the Empire's enthusiasm for the navy and maritime trade was to end. This was due to the high cost of conducting the voyages, the growing continental threat to the ruling dynasty, Confucian opposition to foreign contact, as well as a

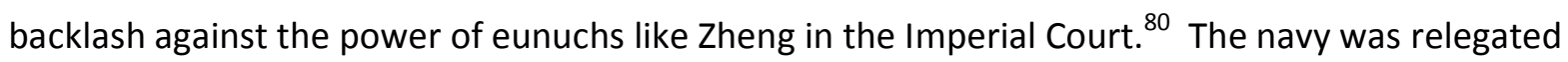
to the position of a coast guard and its main role was keeping piracy under control along China's coasts and rivers. ${ }^{81}$ For 400 years this limited role for the navy was all that was required as the main threats to dynasties come from the continent rather than the sea. ${ }^{82}$ This stagnation in the operations of the navy and its technological development would have a devastating effect on China with the arrival of modern European navies in the $19^{\text {th }}$ century.

The Chinese navy was subjected to the full force of modern European military technology during the First Opium War, and was revealed to be entirely obsolete. The war began in 1840 between

\footnotetext{
${ }^{78}$ Cole, The Great Wall at Sea, 1-3.

${ }^{79}$ Hok-lam Chan, "The Chien-Wen, Yung-Lo, Hung-Hsi, and Hsüan-Te Reigns, 1399-1435," in The Cambridge History of China Vol. 7, Part 1: The Ming Dynasty, 1368-1644, Part I, ed. Frederick W. Mote and Denis Twitchett (Cambridge: Cambridge University Press, 1998), 270-71.

${ }^{80}$ Cole, The Great Wall at Sea, 3.

${ }^{81}$ Chan, "The Chien-Wen, Yung-Lo, Hung-Hsi, and Hsüan-Te Reigns, 1399-1435," 302-03.

${ }^{82}$ Cole, The Great Wall at Sea, 3-4.
} 
China and the United Kingdom over the right of British traders to sell opium in China, as well as other grievances, and would eventually involve France and the USA as well. ${ }^{83}$ Following the crushing defeats of the Opium Wars, efforts were made to modernise the navy by emulating European technologies, but it never gained the support and funding needed to build a force capable of fending off the large and sophisticated naval forces of the Western Powers. ${ }^{84}$ The Imperial Navy suffered heavy defeats at the hands of the French in 1884, and the Japanese in 1894 and $1895 .^{85}$ During the Republican period, which lasted from 1912 to the outbreak of the Civil War in 1945, the navy was again a low priority for a state divided amongst warlords and occupied by foreign powers backed by their own powerful navies. What warships the Republic did possess were either those left from the Dynastic period or purchased from overseas. ${ }^{86}$ The maritime heritage of pre-communist China shows that, while it had been a great naval power, legitimate and pressing continental threats had been greater than those from the sea for much of its history and made the navy a low priority. Only with the arrival of European powers to the region did China face a sea-born threat to its security, and by then 400 years of neglect left it in no position to compete with modern navies in combat or defend its shores.

\section{Civil War Origins and the First Decade}

The PLAN had its origins during the final years of the Chinese Civil War. In 1949, Chinese nationalist forces, properly referred to as the Kuomintang (KMT), began withdrawing from the mainland onto several islands, including Taiwan, Jinmen, Hainan, and Zhoushan. ${ }^{87}$ The Communist forces required naval equipment with which it could conduct amphibious landings in order to retake these islands. One of the first of these landings was undertaken on 24 October 1949, on Jinmen Island, with PLA forces using 200 fishing junks to land a first wave of 10,000 troops. The landing was a disaster, with KMT forces destroying the transports in the first wave, preventing any reinforcement being sent to support the initial landing. After three days of fighting the PLA forces

\footnotetext{
${ }^{83}$ Frederic Wakeman, "The Canton Trade and the Opium War," in The Cambridge History of China, Volume 10, Part 1: Late Ch'ing 1800-1911, Part I, ed. John K. Fairbank, The Cambridge History of China (Cambridge: Cambridge University Press, 1978), 195-201; John K. Fairbank, "The Creation of the Treaty System," in The Cambridge History of China, Volume 10, Part 1: Late Ch'ing 1800-1911, Part I, ed. John K. Fairbank, The Cambridge History of China (Cambridge: Cambridge University Press, 1978), 243-49.

${ }^{84}$ Kwang-Ching Liu and Richard J. Smith, "The Military Challenge: The North-West and the Coast," in The Cambridge History of China, Volume 11, Part 2: Late Ch'ing, 1800-1911, ed. Jonh K. Fairbank and Kwang-Ching Liu, The Cambridge History of China (Cambridge: Cambridge University Press, 1980), 247-50; Ting-yee Kuo and Kwang-Ching Liu, "SelfStrengthening: The Pursuit of Western Technology," in The Cambridge History of China, Volume 10, Part 1: Late Ch'ing 1800-1911, Part I, ed. John K. Fairbank, The Cambridge History of China (Cambridge: Cambridge University Press, 1978), 519-25, 42.

${ }^{85}$ Liu and Smith, "The Military Challenge: The North-West and the Coast," 251-52, 69-73.

${ }^{86}$ Cole, The Great Wall at Sea, 5-6.

${ }^{87}$ Xiaobing Li, A History of the Modern Chinese Army (Lexington: The University Press of Kentucky, 2007), 130. 24
} 
DEFENSIVE REALISM AND CHINESE MARITIME STRATEGY

were defeated with a loss of 9,000 men, including 3,000 taken captive. ${ }^{88}$ Following the defeat, all amphibious operations were halted and the PLA high command had the Twelfth Army Group, Fourth Field Army's headquarters reorganised, creating the headquarters of the PLAN. The Twelfth Army Group's commander, Senior General Xiao Jinguang, became the PLAN's first commander. Xiao had been a member of the Chinese Communist Party (CCP) since 1920 and was both a veteran of the Long March and a distinguished field officer. He was selected for his political reliability and combat record, not for any maritime experience. This would be the pattern in the selection of the PLAN commander until $1988 .{ }^{89}$

The PLAN was not completely bereft of warships at its founding. In April of 1949, 25 KMT warships had defected to the PLA, and sixteen additional escorts and gunboats were rapidly repaired so that they could be added to the order of battle. Expanding the navy was a top priority for Mao Zedong and the communist leadership, as it would be required to finally defeat the KMT by assaulting the islands they held. The Sino-Soviet Treaty of Friendship, Alliance, and Mutual Assistance was signed in February 1950, and provided for $\$ 300$ million in loans for the new Chinese government. Mao used half of this money to place orders for ships and equipment for the navy. ${ }^{90}$ In 1959 the Soviet Union provided the PRC with the licences to produce ballistic-missile submarines, medium attack submarines, two variants of missile boat, torpedo boats, and submarine and surface launched anti-ship missiles. These would be the designs that the PLAN would base the majority of its fleet on for the remainder of the century. ${ }^{91}$ This initial focus on the PLAN did not last past the outbreak of the Korean War, and a resulting shift in China's military priorities to ground combat. The positioning of the US Seventh Fleet in the Taiwan Strait during the war also made any further action against the KMT forces on Taiwan impossible, though a few smaller islands were retaken. At the conclusion of the Korean War, the leadership of the PLA saw maritime forces as having played only a minor role in the conflict, which served to reinforce their view of the primacy of land forces and that the navy should be limited to a coastal defence role. The result was the PLAN being given a lower funding priority for the decade following the Korean War. ${ }^{92}$

\footnotetext{
88 Ibid., 131.

${ }^{89}$ Bernard D. Cole, "The People's Liberation Army Navy after Half a Century: Lessons Learned in Beijing," in The Lessons of History: The Chinese People's Liberation Army at 75, ed. Laurie Burkitt, Andrew Scobell, and Larry M. Wortzel (Carlisle, PA: Strategic Studies Institute, United States Army War College, 2003), 164.

${ }^{90} \mathrm{Li}$, A History of the Modern Chinese Army, 131.

91 John w. Lewis and Xue Litati, China's Strategic Seapower: The Politics of Force Modernization in the Nuclear Age (Stanford: Stanford University Press, 1994), 81.

${ }^{92}$ Cole, "The People's Liberation Army Navy after Half a Century: Lessons Learned in Beijing," 168-70.
} 
During its first decades, the strategy of the PLAN, as much as it can be said to have one, was an adaptation of the Young School, an approach developed by the Soviet Union during its own Civil War and so well suited to the PRC at that point in time..$^{93}$ This approach was combined with Mao's concept of a people's war to create operation guidance under which the PLAN operated. Devised by the now Admiral Xiao Jinguang, the guidance envisioned the PLAN as a light force operating in support of ground forces. ${ }^{94}$ The main responsibility of the PLAN was the defence of the Chinese coastline 12 nautical miles out to sea and $300 \mathrm{~km}$ inland in the face of raids by the KMT. This was mostly achieved by land forces rather than warships. ${ }^{95}$ The other task was protecting fishing ships and maritime commerce from attacks by the KMT's naval forces, and this was only achieved in the late 1960s. An effort to develop a more comprehensive Chinese strategy for maritime defence, based on Soviet models, began in 1954 at the Nanjing Military Academy, but came to a halt with a political campaign against 'dogmatism' in 1959, and would not restart until Mao's death in $1976 .{ }^{96}$ The breakdown of the Sino-Soviet relationship in late 1960s resulted in a further marginalisation of the PLAN as the focus shifted from the south and east coast, which were threatened by the KMT, to the northern land border and the threat of the Soviet Union. ${ }^{97}$

\section{People's War}

In order to understand the subordinate role that the navy played in the thinking of China's leadership, the military strategy of the PLA, people's war, needs to be explained. People's war doctrine was developed by Mao Zedong and was based on his experience in the struggle against the Japanese during WWII, a period in which the KMT controlled frontline operations and so only guerrilla activities were open to communist forces. ${ }^{98}$ The doctrine was intended as a method of defending China against the superior nuclear and conventional forces of either the Soviet Union or the USA. One of the fundamental aspects of people's war is that politics and men are more important than sophisticated weapons. The Chinese people, fully indoctrinated and mobilised, was said to constitute a weapon far more potent than nuclear weapons. ${ }^{99}$ This stood in opposition to the nuclear, naval and air power of the USA, USSR, and UK. These states were described as 'paper tigers', not necessarily because they lacked power, but because the march of history dictated that

\footnotetext{
${ }^{93}$ Ibid., 163.

${ }^{94}$ You, "The Evolution of China's Maritime Combat Doctrines and Models : 1949-2001," 5.

${ }^{95} \mathrm{Li}$, "The Evolution of China's Naval Strategy and Capabilities: From "near Coast" and "near Seas" to "Far Seas", 146.

${ }^{96}$ You, "The Evolution of China's Maritime Combat Doctrines and Models : 1949-2001," 4-5.

${ }^{97}$ Cole, "The People's Liberation Army Navy after Half a Century: Lessons Learned in Beijing," 173.

${ }^{98}$ Harlan W. Jencks, "'People's War under Modern Conditions": Wishful Thinking, National Suicide, or Effective Deterrent?," The China Quarterly, no. 98 (1984): 311.

${ }^{99}$ Ralph L. Powell, "Maoist Military Doctrines," Asian Survey 8, no. 4 (1968): 241-42. 
DEFENSIVE REALISM AND CHINESE MARITIME STRATEGY

imperialism and capitalism will inevitably fall. Due to this inherent internal weakness, these

regimes were forced to place all their faith in sophisticated weapons, but these would not prevent their demise. ${ }^{100}$ Practically speaking, people's war relied in defence in depth, based on the use of China's vast geographic area and population, as well as the dispersal of industry, to force any invader to fight a protracted war against numerous Chinese guerrillas in its rear, while also facing conventional Chinese units at the front. ${ }^{101}$ As can readily be seen, there is no role for the navy in such a war, and the development of the fleet actually stood opposed to people's war in many respect. To invest in advanced technology was to put faith in the same 'paper tigers' which Mao and other Chinese leaders so derided the west for. As the status of Mao continued to rise, particularly during the Cultural Revolution, it became more and more difficult to question the doctrine of people's war and the subordinate status it gave the PLAN.

\section{The Cultural Revolution}

Between 1967 and 1969, the PLAN became embroiled in the Cultural Revolution that had been sweeping the country since 1966 . During this period, over 80,000 officers were accused of political disloyalty and other crimes, and were purged from the service. 1,169 of these officers would later be executed or die due to torture or starvation. Research programmes and military academies were shut down and regular training ground to a halt. Marshall Lin Biao, head of the PLA and vice chairman of the CCP during the Cultural Revolution, stacked the leadership of the PLA with his supporters, who in turn selected leaders based on their political loyalty, further crippling the PLAN. ${ }^{102}$ The relationship between Lin and Mao deteriorated in 1970, and resulted in Lin's death in a plane crash in 1971 as he fled China. Following his death there were further reforms of the PLA as generals and programmes associated with Lin were removed and cancelled. The Lin affair also resulted in a "precipitous decline in the military budget" from $1971 .{ }^{103}$ The Cultural Revolution can be characterised as a lost ten years in China's development, but analysing global naval development during the period, Bernard Cole puts the damage to PLAN modernisation at two decades. ${ }^{104}$ Any technological development within the fleet progressed slowly and at a high cost,

\footnotetext{
100 _- - "Great Powers and Atomic Bombs Are "Paper Tigers"," The China Quarterly, no. 23 (1965): 55-56.

${ }^{101}$ Powell, "Maoist Military Doctrines," 243-44.

102 Li, A History of the Modern Chinese Army, 234-35.

103 Thomas W. Robinson, "Chinese Military Modernization in the 1980s," The China Quarterly, no. 90 (1982): 237.

${ }^{104} \mathrm{Li}$, A History of the Modern Chinese Army, 236-37.
} 
and this, along with the effects of purges and politicisation, would have a lasting effect on the PLAN. ${ }^{105}$

\section{The Rise of Deng Xiaoping and the Navy}

The 1970s saw the start of a series of processes which would lead to an expansion of the role of the PLAN in the 1980s. The PLAN had its first blue water task when it was required to monitor tests of the Dong-Feng 5 (DF-5) ballistic missile in 1972, and this lead Admiral Xiao to push for a blue water fleet. ${ }^{\dagger}$ The need for this fleet was further demonstrated when the PLAN were required to conduct operations in the Parcel Islands against the South Vietnamese Navy in $1974 .{ }^{106}$ By 1975 Mao had declared the PLAN as being inadequate for current and future needs, and in July of that year he approved a plan by Admiral Xiao to modernise the PLAN. ${ }^{107}$ The death of Mao and the ascent of Deng Xiaoping was another momentous event in the PLAN's history. Under Deng, 'people's war' became 'people's war under modern conditions', and military modernisation became a stated goal of China's leadership. ${ }^{108}$ The 1970 s also saw the navy adopt new tactics as it focused its attention on the threat of Soviet invasion through the Bohai Sea and landing amphibious forces near Beijing. ${ }^{109}$ Due to the superiority of the enemy, Chinese forces would conceal themselves along the coast as the enemy fleet approached, and then attack from multiple directions as landing forces transferred ships and prepared for the drive to shore. Attacking at these times would cause maximum casualties and disruption, but the tactics were still mostly delaying actions relying on the army to achieve final victory. ${ }^{110}$

In 1979, Deng approved an extension of the navy's area of responsibility from the near-coast to the near-sea. ${ }^{111}$ The shift was driven by Admiral Liu Huaqing, a man now considered the father of the modern PLAN. ${ }^{112}$ Like Xiao, Liu was a veteran of the Long March, but Liu had undergone naval

\footnotetext{
${ }^{105}$ Elizabeth Speed, Chinese Naval Power and East Asian Security, Working Paper No. 11 (Vancouver: Institute of International Relations University of British Columbia, 1995).

Robinson, "Chinese Military Modernization in the 1980s," 223.

Cole, "The People's Liberation Army Navy after Half a Century: Lessons Learned in Beijing," 173.

+ The definition of a blue water navy is one that can conduct operations over 200 miles from shore. David Scott, India's Drive for a 'Blue Water' Navy, vol. 10, 2008 (2008), 1.

${ }^{106}$ You, "The Evolution of China's Maritime Combat Doctrines and Models : 1949-2001," 5.

107 Speed, Chinese Naval Power and East Asian Security, 4.

You, "The Evolution of China's Maritime Combat Doctrines and Models : 1949-2001," 5.

${ }^{108} \mathrm{Li}$, "The Evolution of China's Naval Strategy and Capabilities: From "near Coast" and "near Seas" to "Far Seas"," 147. Speed, Chinese Naval Power and East Asian Security, 4.

${ }^{109}$ You, "The Evolution of China's Maritime Combat Doctrines and Models : 1949-2001," 14.

${ }^{110} \mathrm{Li}$, "The Evolution of China's Naval Strategy and Capabilities: From "near Coast" and "near Seas" to "Far Seas", " 147-48.

You, "The Evolution of China's Maritime Combat Doctrines and Models : 1949-2001," 14-15.

${ }^{111} \mathrm{Li}$, "The Evolution of China's Naval Strategy and Capabilities: From "near Coast" and "near Seas" to "Far Seas"," 150.

112 You, "The Evolution of China's Maritime Combat Doctrines and Models : 1949-2001," 6.
} 
DEFENSIVE REALISM AND CHINESE MARITIME STRATEGY

training in the USSR from 1954 to 1958 . He would go on to draft the strategy of near-seas active defence which would be adopted in 1987. This new area of responsibility would be patrolled by the new surface combatants and submarines that had come into service with the fleet during the 1970s. The Han-class (Type 091) nuclear-powered attack submarine (SSN) had been built as part of a push to build nuclear-powered ballistic missile submarines (SSBN). New Luda-class (Type 051) guided-missile destroyers (DDG) and Jianghu-class (Type 053) guided-missile frigates (DDG) also entered into service, giving the PLAN a higher number of large surface combatants than it had ever possessed before. Like the SSNs, these ships were not developed specifically for the new mission, rather to support ballistic missile testing in the Pacific Ocean, but were too large to slot into the existing in-shore defence strategy. ${ }^{113}$ The extension of the PLAN's area of responsibility, which would in the next decade carry through to a new maritime strategy for the PLAN, is therefore likely due to both a change in leadership in the PRC and a change in composition of the PLAN fleet.

\section{0s: More Responsibility, Less Funding}

The 1980s saw a reassessment of the threat environment that the PRC faced, particularly on the maritime front. With the improvement of the relationship between China and the USA, the Chinese leadership could now rely on the protection of the American fleet to defend the Chinese coast from a Soviet attack. ${ }^{114}$ Two other events also contributed to a decline in the funding received by the PLAN and the PLA generally. The 1979 war between Vietnam and China had a very limited role for the PLAN, confined to the surveillance of Soviet forces deployed in the region, with no combat between the Vietnamese and Chinese Navies. ${ }^{115}$ The war showed up significant deficiencies in PLA ground forces and rectifying these was a priority that resulted in funds being diverted from the PLAN. ${ }^{116}$ Deng's programme of modernising the Chinese economy, which began in 1985, also resulted in a dramatic decline in military spending. This would particularly affect the navy, as projects like warships are capital intensive and were difficult to justify in the face of other defence needs. This decline in defence spending contrasted with a dramatic increase in the responsibilities of the PLAN. These were brought about by a new strategy devised by Admiral Liu in

\footnotetext{
${ }^{113} \mathrm{Li}$, "The Evolution of China's Naval Strategy and Capabilities: From "near Coast" and "near Seas" to "Far Seas", 149.

${ }^{114}$ Cole, "The People's Liberation Army Navy after Half a Century: Lessons Learned in Beijing," 175.

${ }^{115}$ Kenneth G. Weiss, The Sea Is Red: The Sino-Soviet Rivalry and Its Naval Dimension, Professional Papper 421

(Alexandria, VA Center for Naval Analyses, 1984), 25-26.

${ }^{116}$ Cole, "The People's Liberation Army Navy after Half a Century: Lessons Learned in Beijing," 175.
} 
the early 1980s and accepted as China's maritime policy in 1987. This strategy was summarised as "defend actively, operate in the near seas". ${ }^{117}$ The near seas were defined as,

“1) the first island-chain, which stretches from the Kurile islands through the islands of Japan, Ryukyu Archipelago, Taiwan, the Philippines to Borneo Island; 2) the Yellow Sea, East China Sea and South China Sea, or the three near seas within the inner rims of the first island-chain, and 3) sea areas adjacent to the outer rims of this island-chain, and those of the north Pacific."118

The PLAN's new strategy broke the navy from its previous supporting role to ground forces and gave it independent tasks, including the restoration of lost or disputed maritime territories (including Taiwan), protecting maritime resources, and securing major SLOC in the event of war, as well as conventional defence and deterrence, and nuclear deterrence. ${ }^{119}$ This new strategy was in line with the new overall military strategy of the PRC approved by the Central Military Commission in 1985. The new strategy shifted the PLA's focus from preparing for a nuclear war with the USSR to preparing for local and limited wars on China's periphery. ${ }^{120}$

The continuing constraints on the PLAN's budget could be seen in the acquisition of new classes of ship. While Jianghu and Luda class ships continued to be produced, newer surface combatants were not, due to limited funding, and because any warships that China were to build would be based on obsolete technology in terms of propulsion, information technology, and other key areas. This obsolescence was so great as to compromise a ships ability to operate in the newly expanded operational area. ${ }^{121}$ The only significant additions to the fleet in this period were two new classes of submarines. The Ming-class (Type 035) submarine (SS) entered service, though this class represented only an update of the Romeo class of SS, the design of which China purchased from the USSR in 1959. The other was the Xia-class nuclear-powered ballistic missile submarine (SSBN) which finally became operational after decades of research and six years of fit out and testing. However the Xia would never complete a deterrence cruise, and even if it did, three of the class would be required for an effective continuous nuclear deterrent. ${ }^{122}$

\footnotetext{
${ }^{117} \mathrm{Li}$, "The Evolution of China's Naval Strategy and Capabilities: From "near Coast" and "near Seas" to "Far Seas", " 150, 56.

${ }^{118}$ Ibid.: 150.

119 Ibid.

${ }^{120}$ Cole, "The People's Liberation Army Navy after Half a Century: Lessons Learned in Beijing," 176.

${ }^{121} \mathrm{Li}$, "The Evolution of China's Naval Strategy and Capabilities: From "near Coast" and "near Seas" to "Far Seas", " 156-57.

122 Ibid.: 152. 
DEFENSIVE REALISM AND CHINESE MARITIME STRATEGY

1985 saw the fleet complete its first foreign port call, a visit by a Luda-class destroyer and a replenishment ship to Pakistan, Sri Lanka and Bangladesh. The visit was initiated on orders of the Chinese leadership who wished to use the PLAN to further the PRC's diplomatic interests with these states. The task force appears to have had some difficulties with underway replenishment in inclement sea conditions, and the ability to resupply ordnance to the warship at sea was also limited. ${ }^{123}$ These tasks were vital to the PLAN's ability to operate within the near seas. An additional trip by the training ship Zhenghe was made to Hawaii in 1989. By the 1990s, port visits by the PLAN became a regular occurrence in Asia, and then further afield. ${ }^{124}$ But the PLAN was still limited in the operations that it could conduct far from the Chinese mainland. Violence in Somalia in 1991 lead to a request for the evacuation of personnel from the Chinese embassy, however the PLAN had no assets that could conduct that type of operation at such a great distance from the mainland. Civilian cargo ships had to be diverted in order to evacuate the staff, with local tugboats transferring people from shore to ship. ${ }^{125}$ While this was an embarrassment to the PLAN, it did not result in any significant boost to the funding or the priority of the navy, this would come in the mid-1990s following the Taiwan Strait Crisis.

\section{The Taiwan Strait Crisis}

The origins of the crisis itself lie in Chinese perceptions that the US policy towards Taiwan was shifting towards a more pro-independence position than it had previously taken, one that was at odds with private assurances made by Washington to Beijing. ${ }^{126}$ The Chinese leadership also wished to influence the elections that were taking place on the island at the end of 1995 and beginning of 1996, hoping to dissuade residents of Taiwan from voting for pro-independence parties and candidates. In response to these events in both the US and Taiwan, the PLA conducted a series of exercises centred on the Nanjing military district across the Strait from Taiwan. ${ }^{127}$ Held between July 1995 and March 1996, these exercises included amphibious landings, bombing by the PLA Air Force (PLAAF), and live naval fire by the PLAN off the coast of Fujian. ${ }^{128}$ The most

\footnotetext{
${ }^{123}$ Christopher D. Yung et al., China's out of Area Naval Operations: Case Studies, Trajectories, Obstacles, and Potential Solutions, vol. 3, Inss China Strategic Perspectives (Washington. D.C.: National Defence University Press, 2010), 11-14. ${ }^{124}$ Cole, The Great Wall at Sea, 17.

${ }^{125}$ Yung et al., China's out of Area Naval Operations: Case Studies, Trajectories, Obstacles, and Potential Solutions, 1415.

${ }^{126}$ Arthur S. Ding, "The Lessons of the 1995-1996 Taiwan Stratit Crisis: Developing a New Strategy Towards the United States and Taiwan," in The Lessons of History: The Chinese People's Liberation Army at 75, ed. Laurie Burkitt, Andrew Scobell, and Larry M. Wortzel (Carlisle, PA: Strategic Studies Institute, United States Army War College, 2003), $380-82$. ${ }^{127}$ Robert S. Ross, "The 1995-96 Taiwan Strait Confrontation: Coercion, Credibility, and the Use of Force," International Security 25, no. 2 (2000): 101-05.

${ }^{128}$ Andrew Scobell, "Show of Force: Chinese Soldiers, Statesmen, and the 1995-1996 Taiwan Strait Crisis," Political Science Quarterly 115, no. 2 (2000): 232.
} 
provocative actions were the test firing of a total of ten DF-15 short-range ballistic missiles, some landing as close as 20 miles from major Taiwanese ports. ${ }^{129}$ Reacting to these provocations, and mindful of the need to reassure other Asian allies that it took its security promises seriously, the US deployed two aircraft carrier battle groups to the region in March of 1996. The USS Independence and its group sailed from Okinawa and took up station in the seas east of Taiwan. The USS Nimitz and its group redeployed from the Persian Gulf to the Philippine Sea so that it could respond quickly to any changes in the situation. ${ }^{130}$ The deployment of the two carriers and their associated forces represented the largest deployment of US forces in the region since the end of the Vietnam War and was a clear demonstration of US commitment to its allies. ${ }^{131}$ The crisis wound down as the US forces quietly observed the PLA exercises as they concluded, and Taiwan conducted the second of its elections and took no further steps towards independence. In the end, both the PRC and USA achieved their goals, the US having demonstrated its commitment to the region, and the PRC showing the importance it placed on the issue of Taiwanese independence and causing a change of US policy in which a more cautious approach was taken to relations with Taiwan. ${ }^{132}$ But for the PLAN, the crisis would bring in a new factor to its planning, the US Navy.

The Taiwan Strait Crisis is the line that this paper will use as the start point for the current modernisation programme of the PLAN. It represented a new focus by the PLAN on the involvement of the USA in any armed conflict. ${ }^{133}$ The crisis would trigger a funding increase for the PLAN and lead to the purchase of new, Russian made vessels. The Chinese "proceeded to develop forces centred on air, naval, and missile platforms to foreclose future American interventions."134 Countering a US intervention was now seen as vital if China was maintain its security and territorial integrity by ensuring Taiwan could not unilaterally declare independence. While elements of China's modernisation efforts predate this period, these efforts were likely reinforced

\footnotetext{
${ }^{129}$ Ross, "The 1995-96 Taiwan Strait Confrontation: Coercion, Credibility, and the Use of Force," 107; Scobell, "Show of Force: Chinese Soldiers, Statesmen, and the 1995-1996 Taiwan Strait Crisis," 232.

${ }^{130}$ Ross, "The 1995-96 Taiwan Strait Confrontation: Coercion, Credibility, and the Use of Force," 110.

${ }^{131}$ Ding, "The Lessons of the 1995-1996 Taiwan Stratit Crisis: Developing a New Strategy Towards the United States and Taiwan," 379.

132 Ross, "The 1995-96 Taiwan Strait Confrontation: Coercion, Credibility, and the Use of Force," 112, 18-19.

${ }^{133}$ Ding, "The Lessons of the 1995-1996 Taiwan Stratit Crisis: Developing a New Strategy Towards the United States and Taiwan," 388, 87.

${ }^{134}$ Toshi Yoshihara and James Holmes, "Command of the Sea with Chinese Characteristics," Orbis 49, no. 4 (2005): 689. 32
} 
DEFENSIVE REALISM AND CHINESE MARITIME STRATEGY

and accelerated by the crisis. ${ }^{135}$ So it is from this point that the exploration of Chinese naval modernisation will begin.

The history of the PLAN shows its development from a force that existed purely to support the army to an independent, strategic force. The major driver of change in China's maritime strategy was changes in the greatest perceived threat to the county's territory. Other shifts were a result of finding places for ships not constructed of military necessity. The threats to China's territory shaped its military forces in a way that defensive realists would expect. Chinese efforts were focused on develop a force to suit its security threats. Military power was shaped towards defence, rather than a force that could expand Chinese territory or influence. The navy's limited utility in the defence of China sidelined it for most of the PRCs history, and only the recognition of the threat that US naval forces posed against Chinese territory and territorial integrity changed this. Another striking aspect of the history of the PLAN is its failure to develop into a modern force over the first 50 years of its existence. The Cultural Revolution certainly had a role to play in this, as did the commitment to people's war which only abetted after the death of Mao. It left the PLAN with a fleet based on 1950s Soviet designs and bleeding edge technology which resulted in a single and almost entirely useless SSBN. These are the conditions which the PLAN now seeks to overcome to become a modern, effective navy.

\footnotetext{
${ }^{135}$ Ronald O'Rourke, China Naval Modernization: Implications for U.S. Navy Capabilities-Background and Issues for Congress (Washington D.C.: Congressional Research Service, 2011), 2-3.
} 


\section{MODERNISATION OF THE FLEET}

\section{Motivations}

While this paper will begin the discussion of the modernisation efforts of the PLAN from the 1996 Taiwan Straits Crisis, this was not the sole factor that led to a greater focus on the need for a modernised navy. Territorial integrity, economic and energy concerns, and the implications on Chinese security of the Persian Gulf War and the Kosovo intervention also played into the development of the PLAN and strategy during this period. An additional motivation that would be posited by offensive realists is that China is seeking to push the US out of Asia in order to establish hegemony in the region, and therefore the modernising of the navy is part of this drive. Defensive realists instead focus on the search for security, which this paper will argue is more important. We will now look at these factors and how they change Beijing's view of the utility of a modern navy.

The first issue which will be addressed here is Taiwan and the concerns associated with it. The Taiwan Strait Crisis showed the Chinese leadership, in extremely stark terms, how seriously the USA took the issue of Taiwanese self determination. The deployment of two aircraft carriers and their battle groups to the region was an unexpected and startling action to Beijing. While the US had long standing commitments to Taiwan's defence, Chinese authorities had not bargained on the US being prepared to use force to defend it, and had it not been for the Chinese missile tests the US may not have. ${ }^{136}$ The PLA now had to devise strategies that could prevent US interference in any future conflict to prevent Taiwanese independence, thereby maintaining Chinese territorial integrity and security. As any US intervention would have to come by sea, it was natural that the PLAN would be the main beneficiary of a resulting increase in spending. Military forces would also need to be able to effectively deter any further moves towards independence by Taiwanese authorities. The military advantage that Taiwan maintained over the mainland had allowed Taiwanese leaders to make the bold movements in the direction of independence that was one of the major causes of the $1995-96$ crisis. ${ }^{137}$ By reversing that military advantage China could influence political rhetoric in Taiwan away from independence and towards an outcome that was more on the mainland's terms. The development of the Chinese Navy following the Taiwan Straits crisis was therefore a move to influence the political rhetoric on Taiwan away from independence, and have a capability to forestall US involvement in the event of conflict between China and the rebel province.

\footnotetext{
${ }^{136}$ Ross, "The 1995-96 Taiwan Strait Confrontation: Coercion, Credibility, and the Use of Force," 89.

137 Ibid.: 105.
} 
DEFENSIVE REALISM AND CHINESE MARITIME STRATEGY

The difficulty of countering the capabilities of the US military had been demonstrated by the failure of the militaries of Serbia and Iraq to present any meaningful resistance to US actions in the Kosovo intervention and the Persian Gulf War. These conflicts demonstrated the long range precision strike capabilities that the US military could bring to bear in a conflict. ${ }^{138}$ Both conflicts saw the extensive use of US maritime power, including the use of aircraft carriers and the extensive use of Tomahawk cruise missiles. With a range of $900 \mathrm{~nm}$ (nautical miles) or 1,700 km the Tomahawk cruise missile allowed the US to strake land targets from far off shore. ${ }^{139}$ If the PLA was to counter the threat to the security of the state that such weapons presented, then the maritime zone of control that the PLAN was capable of establishing had to be extended. However, it was not just the capabilities demonstrated in these conflicts that troubled Beijing. The Kosovo intervention was justified without the authorisation from the United Nations, instead universal human rights were invoked as a sufficient justification for the intervention. China saw this as a precedent that could also be applied to Taiwan and even Tibet. It was felt that the PLA had to be prepared to defend China from the threat to its sovereignty that such an intervention would present. $^{140}$

Economic and energy concerns are also one of the major contributors to the drive for naval modernisation in the period following the Taiwan Strait Crisis. The economy of China has grown at a staggering rate over the past two decades and this is important in terms of motivating and paying for the modernisation of the PLAN. Economic growth plays into the need for a more effective navy in four ways. The first is due to the fact that China's economic growth has centred itself along the coast, and this leaves it vulnerable to attack from the sea, attacks which the US military has proven a devastating ability to deliver. ${ }^{141}$ Secondly, with the growth of the Chinese economy, China now relies on maritime trade to fuel its economy. Over 90 percent of China's trade is transported by sea, and a majority of this maritime trade, including $80 \%$ of China's oil needs, has to transit the Straits of Malacca. ${ }^{142}$ This is a natural choke point in which the US maintains an almost constant presence. ${ }^{143}$ Indeed, Singapore, a strong US ally that sits in the

\footnotetext{
${ }^{138}$ Cole, The Great Wall at Sea, 146.

139 "Bgm-109 Tomahawk," Federation of American Scientists, accessed 24 August 2011, http://www.fas.org/man/dod-101/sys/smart/bgm-109.htm.

${ }^{140}$ Arthur S. Ding, "China's Growing Military Capability in Search of a Strategy," The International Spectator: Italian Journal of International Affairs 44, no. 2 (2009): 98.

141 Ibid.: 99.

142 David Lai, "Chinese Military Going Global," China Security 5, no. 1 (2009): 4; Ding, "China's Growing Military Capability in Search of a Strategy," 99.

143 Richard A. Bitzinger, "China's Syndrome : Chinese Military Modernization and the Rearming of Southeast Asia," RSIS Working Papers, no. 126 (2007): 1.
} 
middle of the Strait, has recently modernised Changi Naval Base, making it one of only a few bases in the Pacific large enough to berth a US aircraft carrier. ${ }^{144}$ This ongoing source of concern for Beijing is most frequently referred to as the 'Malacca Dilemma' and, having a navy that is capable of keeping this SLOC open in the event of terrorism or blockage by a third party is a major thrust of naval modernisation in China. ${ }^{145}$ China's territorial claims, and their defence, are the third element in the economic motivations. China's claims in the South China Sea are often pointed to as a likely source of hydrocarbons in the future. If this turns out to be the case, they will help to reduce China's reliance on oil and natural gas transhipped through the Straits of Malacca. ${ }^{146}$ However, in order to establish a favourable outcome in these disputes, China needs to have a navy that can defend its claims and prevent another state establishing control of islands and atolls that China considers its own. China's actions and strategy in the South China Sea will be addressed in greater detail later in this paper. Finally, the expansion of the Chinese economy has led to a massive expansion in Chinese foreign business and investment. The result of this is large numbers of Chinese nationals living and working overseas. After its failure to contribute to the 1991 Somali evacuation, it has been recognised that the PLAN needs to have the capability to evacuate these overseas workers if required. ${ }^{147}$ All these motivations can be attributed to China's search for security in its territory, trade, and for its citizens, wherever they may be.

The use of the PLAN to evacuate Chinese citizens is not the only humanitarian motivation behind Chinese naval modernisation since 1996. The 2004 Boxing Day tsunami which devastated parts of Indonesia, Malaysia and many other states, demonstrated the soft power value of naval forces. The deployment of US aircraft carriers to the region, as well as the transport and warships of numerous other nations, provided a major public relations boon to these states. This was a benefit that China largely missed due to it navy's inability to react rapidly and with the right type of ship for humanitarian relief. ${ }^{148}$ Beijing recognises the benefit of having a navy capable of rapidly conducting humanitarian relief operations, and so this has also fed into its modernisation efforts.

As can be seen, the motivations behind the modernisation of the PLAN and other PLA forces associated with maritime security are centred on guaranteeing the security and interests of China.

\footnotetext{
${ }^{144}$ Felix K. Chang, "In Defense of Singapore," Orbis 47, no. 1 (2003): 115.

145 Ding, "China's Growing Military Capability in Search of a Strategy," 99.

${ }^{146}$ Leszek Buszynski and Iskandar Sazlan, "Maritime Claims and Energy Cooperation in the South China Sea," Contemporary Southeast Asia 29, no. 1 (2007): 155-56.

${ }^{147}$ O'Rourke, China Naval Modernization: Implications for U.S. Navy Capabilities-Background and Issues for Congress, 5.

${ }^{148}$ Andrew S. Erickson and Andrew R. Wilson, "China's Aircraft Carrier Dilemma," Naval War College Review 59, no. 4 (2006): 28-29; Li and Weuve, "China's Aircraft Carrier Ambitions: An Update," 26-27. 
DEFENSIVE REALISM AND CHINESE MARITIME STRATEGY

This concept of security includes ensuring China's territorial integrity, something which puts it in competition with other states. For many US commentators, it is China's insistence on ensuring Taiwan continues to be part of one China, that is the hardest to swallow. But whether you believe Taiwan should be independent or not, the more important point is that China sees it as part of the state, and any threat of it breaking away is a threat to the security of the state. To a slightly lesser degree, other territorial disputes fall into the same category, that they are internationally contested is less important to Chinese motivations than the fact that China sees them as being its territory. As well as the territorial threats to the state, China also sees the need to defend its growing interests, including citizens overseas, and the trade lanes that supply the materials to further China's economic growth.

\section{New Historic Missions}

Chinese strategy is not unresponsive to the changes in the international environment and its own position in it. The Chinese reaction to these changes has taken the form of "new historic missions" for the PLA. The missions were first put forward by President Hu Jintao in a December 2004 speech, formally titled "historical missions of the armed forces for the new stage in the new century". ${ }^{149}$ The new historic missions are:

“(1) providing an important guarantee of strength for the party to consolidate its ruling position, (2) providing a strong security guarantee for safeguarding the period of important strategic opportunity for national development, (3) providing a powerful strategic support for safeguarding national interests, and (4) playing an important role in safeguarding world peace and promoting common development."150

The new historic missions demonstrate the Chinese leadership's conclusion that global stability and prosperity is a determinant factor in China's economic and national development, and so adds the goal of securing China's economic development to defence priorities. ${ }^{151}$ The new historic missions have both an internal and external security component, however, internal security is not a major role for the PLAN and so will not be discussed here. The missions continue to place the security and stability of the regime at the forefront of the PLA's missions, and even those tasks

\footnotetext{
${ }^{149}$ Cortez A. Cooper, The PLA Navy's "New Historic Missions": Expanding Capabilities for a Re-Emergent Maritime Power (Santa Monica, CA: RAND Corporation, 2009), 2-3.

150 James Mulvenon, "Chairman Hu and the Pla's "New Historic Missions"," China Leadership Monitor, no. 27 (2009): 2.

${ }^{151}$ M. Taylor Fravel, "Economic Growth, Regime Insecurity, and Military Strategy: Explaining the Rise of Noncombat Operations in China," Asian Security 7, no. 3 (2011): 184; Cooper, The PLA Navy's "New Historic Missions": Expanding Capabilities for a Re-Emergent Maritime Power, 2.
} 
that have an external bent have a regime security motivation, as any external conflict will drain resources needed for domestic reform and stability. Military publications have specifically identified the escalation of territorial disputes and conflict over Taiwan as possible sources of conflict in what has otherwise been identified as a period of strategic opportunity for China's economy based on a stable international environment. These publications envisage that the role of a strong Chinese military will not be to solve disputes through the use of force, but to deter other states from challenging the status quo. ${ }^{152}$ These new historic missions are in line with the expectations of defensive realism. The Chinese government has identified that it is seeking security rather than power, building up its military only in so far as it allows China to continue its economic development and maintain its territorial integrity. In identifying global stability as a key to continued domestic growth the New Historic Missions also show that the Chinese government are not pushing for the type of regional hegemony portrayed by offensive realists as any such moves would be grossly destabilising and harmful to domestic interests.

\section{Sources of Chinese Military Equipment}

Now that motivations behind the modernisation of the PLAN have been discussed, this paper will look at how this modernisation has taken place. This will be done by looking at the foreign and domestic sources of military hardware for the PLA; what the composition of the modern PLAN fleet is, including supporting units such as aircraft of the PLA Air Force (PLAAF); as well as how the PLAN has sought to improve training and professionalism within the service. The development of China's paramilitary maritime forces will also be examined, as these are playing an increasingly important role in many of China's maritime disputes. Finally, the modernisation of the PLAN and supporting units will be compared against two of its neighbours, Japan and Vietnam, in order to gain perspective on China's military growth. China's naval building programme is driven by a real need to modernise an otherwise largely obsolete fleet. However, the growth of its para-military fleet is one of the most problematic aspects of China's increasing focus of maritime security.

China's indigenous shipbuilding industry constructs almost all of the PLAN's ships, and in the area of civilian shipbuilding it is world leading. The Chinese government has recognised the strategic nature of a domestic shipbuilding industry, and so has a stated intent to support and develop the sector; their goal was to have the country become the world's largest shipbuilder by 2015, a goal it

\footnotetext{
${ }^{152}$ Fravel, "Economic Growth, Regime Insecurity, and Military Strategy: Explaining the Rise of Noncombat Operations in China," 187. 
DEFENSIVE REALISM AND CHINESE MARITIME STRATEGY

actually achieved in 2010. ${ }^{153}$ Chinese shipbuilders have leveraged lessons learnt from interactions with foreign shipbuilders to improve their research, development, and production process which have had benefits for military projects. ${ }^{154}$ Shipbuilding was one of the first areas of China's economy to move towards a market based system. The China State Shipbuilding Corporation (CSSC) was created in 1982 as one of the first corporatized areas of China's state run economy. This was then divided into the China Shipbuilding Industry Corporation (CSIC) and CSSC in 1999, with facilities divided between the two on a roughly north-south basis respectively. These are further divided into several shipyard group companies who bid for work on an individual basis rather than as part of the parent corporation. This division at corporation and company level creates a degree of competitiveness not found in other Chinese defence industrial sectors. ${ }^{155}$ However, for all the competitiveness and improvements in Chinese shipbuilding, it still lags behind in several areas which are exacerbated by the demands of military projects. Project management, inefficient production methods, and an inability to develop or absorb advanced production technologies are all weaknesses exhibited in the industry. ${ }^{156}$ A RAND study on the Chinese defence industry picks out particular concerns for defence production:

"Chinese naval shipbuilders still need to import key components or modules, such as propulsion systems, navigation and sensor suites, and major weapon systems, to outfit these vessels. Such a reliance on imported subsystems creates systems-integration challenges, as well as security concerns stemming from dependence on foreign suppliers." 157

The continued reliance on imported components is a significant liability for the PLAN, however overseas equipment purchases also have benefits for both the PLAN and the domestic defence industry.

The acquisition of foreign defence systems has allowed China to field a navy that has capabilities beyond what its own domestic industry is able to produce. While China once acquired military

\footnotetext{
${ }^{153}$ Gabriel Collins and Michael C. Grubb, A Comprehensive Survey of China's Dynamic Shipbuilding Industry: Commercial Development and Strategic Implications, vol. 1, China Maitime Studies (New Port: China Maritime Studies Institute, U.S. Naval War College, 2008), 5, 10; Yonhap, "China Overtakes S. Korea as World's Largest Shipbuilder in 2010," The Asian Age, 13 January 2011, accessed 11 October 2011, http://www.asianage.com/international/chinaovertakes-s-korea-worlds-top-shipbuilder-2010-120.

${ }^{154}$ Evan S. Medeiros et al., A New Direction for China's Defense Industry (Santa Monica: RAND Corporation, 2005$), 110$.

${ }^{155}$ Collins and Grubb, A Comprehensive Survey of China's Dynamic Shipbuilding Industry: Commercial Development and Strategic Implications, 5-10.

156 "Second Report from the Commission to the Council on the Situation in World Shipbuilding," ed. Commission of the European Communities (Brussels: EUR-Lex, 2000), 29-30.

${ }^{157}$ Medeiros et al., A New Direction for China's Defense Industry, 110-11.
} 
equipment from Western sources, an arms embargo placed on China by the USA and European governments as part of the backlash against the 1989 Tiananmen Square massacre halted any trade. Israel was another source of advanced equipment for the PLA, but a reform of Israeli export laws in 2007 halted this trade as well. ${ }^{158}$ This made Russia one of the few states from which China could purchase advanced military hardware. For the two decades following the Tiananmen Incident, China purchased between one-fourth and one-half of all Russian military exports. These purchases helped modernise the PLA and also provided revenue to Russian firms that were no longer receiving large orders from the Russian military. ${ }^{159}$ China's most advanced conventional submarines and destroyers were purchased from Russia and each equips the most advanced Anti Ship Cruise Missiles (ASCM) in the Chinese fleet. ${ }^{160}$ Russia also sells complete aircraft, anti-ship missiles, and air defence systems to China, though the number of complete systems sold is steadily decreasing as Chinese industry catches up. The import of defence equipment by the PLA has allowed for rapid advances in Chinese capabilities, without having to shoulder the research and development costs. ${ }^{161}$ However, as domestic technological ability continues to improve Chinese purchases has been limited to upgrades or specialised technology where Russian industry maintains an advantage. No complete warships have been ordered since $2005 .{ }^{162}$ As well as the importation of complete systems from foreign sources, China also purchases a range of dual-use technologies from countries that include the US and Europe. This includes precision machine tools, diagnostic and forensic equipment, and computer aided design applications. ${ }^{163}$ Overseas purchases have helped China to close capability gaps and acquire advanced capabilities rapidly and at a lower cost than indigenous development.

China also acquires defence technologies through means that are less legitimate. Reverse engineering and industrial espionage continue to play a role in the modernisation of the Chinese military. Reverse engineering has been an issue that Russia in particular faces with its extensive sales of equipment to China. Chinese submarine production, particularly of the new Yuan-class, is thought to be heavily influenced by the lessons learnt from China's Kilo-class submarines. China has also put Russian weapons systems into production in China with only slight modifications in

\footnotetext{
158 Office of the Secretary of Defense, "Military and Security Developments Involving the People's Republic of China 2011," (Washington, D.C.: Department of Defence, 2011), 47-48.

${ }^{159}$ Richard Weitz, "Demise of Russian-Chinese Arms Relationship and Its Korean Implications," International Journal of Korean Unification Studies 18, no. 2 (2009): 89.

160 O'Rourke, China Naval Modernization: Implications for U.S. Navy Capabilities-Background and Issues for Congress, 16.

${ }^{161}$ Weitz, "Demise of Russian-Chinese Arms Relationship and Its Korean Implications," 95; "The People's Liberation Army Navy: A Modern Navy with Chinese Characteristics," (Suitland, MD: The Office of Naval Intelligence, 2009 ), 16.

162 Weitz, "Demise of Russian-Chinese Arms Relationship and Its Korean Implications," 91, 98-99.

163 Defense, "Military and Security Developments Involving the People's Republic of China 2011," 43-44.
} 
DEFENSIVE REALISM AND CHINESE MARITIME STRATEGY

order to avoid paying licensing costs. ${ }^{164}$ Industrial espionage is the other method that the Chinese government has used to acquire advanced technologies for the defence industry. Russia has prosecuted both civilians and military personnel for attempting to sell technology and weaponry to Chinese buyers, though it has refrained from prosecuting the Chinese nationals implicated in such cases. ${ }^{165}$ Industrial espionage is conducted through both traditional intelligence operations and the hacking of computer systems of defence ministries, researchers, and manufacturers. ${ }^{166}$ Reverse engineering and espionage allow China to shorten research and development times for advanced technologies. ${ }^{167}$

While previously China's domestic production of warships had to be augmented by the purchase of ships from Russia, continuing indigenous development, aided by reverse engineering and industrial espionage, has allowed China to rely entirely on its domestic industry. However, China continues to rely on foreign suppliers for specialist components which is a real liability for the PLAN.

\section{The Modern Fleet}

In order to understand the current trajectory of the PLAN, it is important to understand the current state of the PLAN and what its capabilities are. For the purposes of this paper I will discuss six areas: surface combatants, submarines, amphibious support vessels, anti-ship ballistic missiles, aircraft, and aircraft carriers. While this does not cover the entire range of ships in the Chinese fleet, these are the most important vessels to the combat and force projection capabilities of the PLAN. An in-depth knowledge of the submarine tenders, inshore patrol craft, and fleet replenishment vessels is not required to follow this papers argument, suffice to say that like all other areas of the Chinese military, these vessel types are also being modernised.

Nine new, indigenously produced classes of destroyers and frigates have entered service with the PLAN since the early 1990s. The new destroyers surpass the older Luda-class ships, which began service in 1971, in terms of hull design, propulsion, weapons and sensors. The classes are named Luhu, Luhai, Luyang I, Luyang II and Louzhou. However, only thirteen of these ships have entered service with the PLAN since production began in 1994. This slow rate of construction may indicate

\footnotetext{
${ }^{164}$ Weitz, "Demise of Russian-Chinese Arms Relationship and Its Korean Implications," 105.

165 Ibid.: 106-07.

166 John. J. Tkacik, "Trojan Dragon: China's Cyber Threat," Executive Summery Backgrounder, no. 2106 (2008), http://www.policyarchive.org/handle/10207/bitstreams/13468.pdf; Gerald O'Hara, "Cyber-Espionage: A Growing Threat to the American Economy," CommLaw Conspectus 19(2010): 262.

${ }^{167}$ Defense, "Military and Security Developments Involving the People's Republic of China 2011," 44-45.
} 
that the PLAN is incrementally developing technology in each new ship before committing to serial production. ${ }^{168}$ By way of comparison, the US Navy has commissioned 63 of its Arleigh Burke-class destroyers since $1991 .{ }^{169}$ In addition to these, the PLAN also has four Sovremenny-class destroyers, which entered service between 2000 and 2006. Four new classes of frigates have entered service with the PLAN. The classes are two iterations of two designs; Jiangwei I and II, and Jiangai I and II. ${ }^{170}$ The new frigates surpass the older Jianghu-class in both hull design and systems, including anti-air capabilities. The Jiangwei II and Jiangkai // have gone into larger scale production, and Jiangkai II frigates are still being produced. ${ }^{171}$ These new vessels have moved the PLAN from a large fleet of single-mission platforms to a reduced number of more capable and sophisticated multi-mission platforms. ${ }^{172}$, Chinese ship construction has not replaced the majority of the fleet's older ships. The percentage of modern surface combatants in the fleet was still only $25 \%$ in 2010. ${ }^{173}$ Projections for the Chinese fleet out to 2020 actually see a decrease in the number of frigates and a stable number of destroyers. However, the capability of the fleet will improve as older ships are replaced with more modern and capable vessels. ${ }^{174}$

Anti-surface warfare has been a particular focus for the PLAN, both for the surface and submarine forces. The surface warfare force is also seeking to improve its air-defence capability in order to lessen its current dependence on land-based air cover. Anti-submarine warfare is a lesser priority for the PLAN but has not been without progress as well, though this is mostly limited to coastal defence against other regional states diesel submarines, rather than combating US SSNs. ${ }^{175}$ The ASCM of modern Chinese surface combatants are a substantial improvement over older vessels. The SS-N-22 Sunburn ASCM of the Sovremenny-class, coupled with Mineral-ME over-the-horizon targeting radar, has a range of around $130 \mathrm{~nm}$. The Luyang II-class carries the domestically developed C-602 ASCM with an estimated range of $120 \mathrm{~nm}$, and other surface combatants

\footnotetext{
168 O'Rourke, China Naval Modernization: Implications for U.S. Navy Capabilities-Background and Issues for Congress, 35-36.

169 Ronald O'Rourke, Navy DDG-51 and DDG-1000 Destroyer Programs: Background and Issues for Congress (Washington, DC: Congressional Research Service, 2011), 1.

170 James C. Bussert and Bruce A. Elleman, People's Liberation Army Navy: Combat Systems Technology, $1949-2010$

(Annapolis: Naval Institute Press, 2011), 32-36.

${ }^{171}$ O'Rourke, China Naval Modernization: Implications for U.S. Navy Capabilities-Background and Issues for Congress, 37-38.

172 "The People's Liberation Army Navy: A Modern Navy with Chinese Characteristics," 16.

${ }^{173}$ Fravel, "Economic Growth, Regime Insecurity, and Military Strategy: Explaining the Rise of Noncombat Operations in China," 178.

${ }^{174}$ O'Rourke, China Naval Modernization: Implications for U.S. Navy Capabilities-Background and Issues for Congress, 43.

175 "The People's Liberation Army Navy: A Modern Navy with Chinese Characteristics," 17; Owen R. Cote, "Assessing the Undersea Balance between the U.S. And China," MIT Center for International Studies, February 2011, accessed 30 December 2011, http://web.mit.edu/ssp/publications/working_papers/Undersea\%20Balance\%20WP11-1.pdf. 
DEFENSIVE REALISM AND CHINESE MARITIME STRATEGY

(including frigates) carry the C-802 which has a range of approximately $65 \mathrm{~nm} .{ }^{176}$ Area-air-defence is the most notable area of improvement in the fleet. The range of ship borne surface-to-air missiles (SAM) has increased from about seven $\mathrm{nm}$ to between 12 and $80 \mathrm{~nm}$ (depending on the system type) in the space of a decade. The continuing development of the PLAN fleet is evident in that four different SAM systems operate within the modernised fleet, of both Russian and Chinese design. These new SAM systems rely on advanced air-surveillance phased-array radar systems, such as the Russian Tombstone and Top Plate, and the domestically produced Dragon Eye. These new systems give the PLAN surface fleet the ability to engage enemy aircraft before they can launch anti-ship missiles. A single ship can now also take responsibility for the air defence of a surface formation, increasing efficiency. ${ }^{177}$ China's anti-submarine warfare capability continues to be the greatest area of weakness of the PLAN. This has been put down to the high cost of the required platforms and equipment, and the large amount of training time required to master this capability. ${ }^{178}$ This is an admitted flaw that the PLAN is attempting to overcome through the purchase of tools such as modern anti-submarine helicopters and also through the use of antisubmarine mines. These mines are seen as a low cost and effective method of preventing enemy submarines entering the first island chain in the event of a conflict. ${ }^{179}$ The development of surface warfare capabilities within the PLAN has been substantial, but it is important to remember that most of these advances are restricted to the $25 \%$ of the surface fleet that are modern, multirole vessels.

The increased capability of the PLAN is also seen in its submarine fleet. This fleet has conventional, nuclear powered attack, and nuclear powered ballistic missile submarines. The conventional submarines of the Chinese Navy are one of the key capability areas that author James R. Holmes points to in a Chinese access-denial strategy. ${ }^{180}$ As with the surface forces, the PLAN is shifting from large numbers of old and low capability submarines to a smaller number of high capability boats. All of these modern submarines have improved weaponry, larger magazines, are quieter, and benefit from improved computer systems. ${ }^{181}$ China's twelve Russian built Kilo-class submarines are the most advanced conventional submarines in the fleet, with the two Yuan-class

\footnotetext{
${ }^{176}$ Bussert and Elleman, People's Liberation Army Navy: Combat Systems Technology, 1949-2010, 34; "The People's Liberation Army Navy: A Modern Navy with Chinese Characteristics," 18.

177 "The People's Liberation Army Navy: A Modern Navy with Chinese Characteristics," 18.

${ }^{178}$ Yung et al., China's out of Area Naval Operations: Case Studies, Trajectories, Obstacles, and Potential Solutions.

${ }^{179}$ Gabriel Collins et al., "Chinese Evaluations of the U.S. Navy Submarine Force," Naval War College Review 61, no. 1 (2008): 78-80; James C. Bussert, "China Pursues Antisubmarine Warfare," Signal 59, no. 3 (2004): 60-62.

180 James R. Holmes, "Schelling Goes to Sea: Managing Perceptions in China's 'Contested Zone'," Defence Studies 9 , no. 2 (2009): 191-92, 204; Holmes, "China's Way of Naval War: Mahan's Logic, Mao's Grammar," 220, 30, 33.

181 "The People's Liberation Army Navy: A Modern Navy with Chinese Characteristics," 21, 23.
} 
boats being the most advanced indigenously produced conventional submarines. ${ }^{182}$ Slightly older are the thirteen Song-class submarines, which entered service in 1999. These new submarines are superseding the 23 Romeo and Ming-class submarines in the fleet, submarines still based on Soviet designs from 1959. ${ }^{183}$ The Ming-class submarines demonstrated their obsolescence in 2003 when all hands aboard submarine 361 died from asphyxiation due to a mechanical failure. ${ }^{184}$ This incident resulted in the PLAN's commander being relieved of command and being replaced by Admiral Zhang Dingfa, a submariner himself. ${ }^{185}$ The Song, Kilo, and Yuan classes have advanced anti-ship cruise missiles and torpedoes, and it is rumoured that the Yuan-class may have an airindependent propulsion system. ${ }^{186}$ In the area of nuclear powered submarines, China has three new classes that are entering services. Shang-class SSNs have been entering service at a rapid rate, two being commissioned in the past decade, with a possible total of five to be produced. ${ }^{187}$ Retired U.S. Rear Admiral Eric McVadon takes this as a sign that the class has a particular utility in any Taiwan conflict scenario. ${ }^{188}$ There are also plans for an additional class of SSN, the Type 095, and this will take China's nuclear attack submarines from the second generation Shang's into third generation technology, with improvements in quietening and mission capability. ${ }^{189}$ In the area of ballistic missile submarines, China is finally developing a credible second strike capability after the failure of the Xia-class SSBN. The Jin-class is currently under production, and the PLAN is likely to acquire five of these platforms. ${ }^{190}$ However, there have been problems with the JL-2 ballistic missiles, which the Jin's are meant to be equipped with, delaying the class from entering service. ${ }^{191}$ The submarine fleet of the PLAN is one of the areas undergoing the most rapid modernisation. Any discussion of the Chinese submarine fleet is incomplete without a discussion of the acoustic qualities of these ships, which determines how difficult they are to detect. The simplest way to show this is a chart that appeared in a US Office of Naval Intelligence report in 2009 (Figure One). It shows progress in Chinese submarine development but that it still lags behind Russian and US designs. ${ }^{192}$ This leads to the conclusion that while China is improving its

\footnotetext{
${ }^{182}$ Bussert and Elleman, People's Liberation Army Navy: Combat Systems Technology, 1949-2010, 63; "The People's Liberation Army Navy: A Modern Navy with Chinese Characteristics," 23.

${ }^{183} \mathrm{Li}$, "The Evolution of China's Naval Strategy and Capabilities: From "near Coast" and "near Seas" to "Far Seas"," 152.

${ }^{184}$ Beier, "Bear Facts and Dragon Boats: Rethinking the Modernization of Chinese Naval Power," 300.

185 Lyle Goldstein and William Murray, "Undersea Dragons: China's Maturing Submarine Force," International Security 28, no. 4 (2004): 165.

186 "The People's Liberation Army Navy: A Modern Navy with Chinese Characteristics," 23.

${ }^{187}$ Defense, "Military and Security Developments Involving the People's Republic of China 2011," 4.

188 Eric A. McVadon, "China's Maturing Navy," Naval War College Review 59, no. 2 (2006): 97.

189 Defense, "Military and Security Developments Involving the People's Republic of China 2011," 4.

${ }^{190}$ O'Rourke, China Naval Modernization: Implications for U.S. Navy Capabilities-Background and Issues for Congress, 22.

${ }^{191}$ Defense, "Military and Security Developments Involving the People's Republic of China 2011," 3-4, 62.

192 "The People's Liberation Army Navy: A Modern Navy with Chinese Characteristics," 22.
} 
DEFENSIVE REALISM AND CHINESE MARITIME STRATEGY

submarine forces, this is due to a real need to improve the force from outmoded designs. But even this improvement still leaves its submarines, and particularly nuclear powered ones, behind those of the US and Russia.

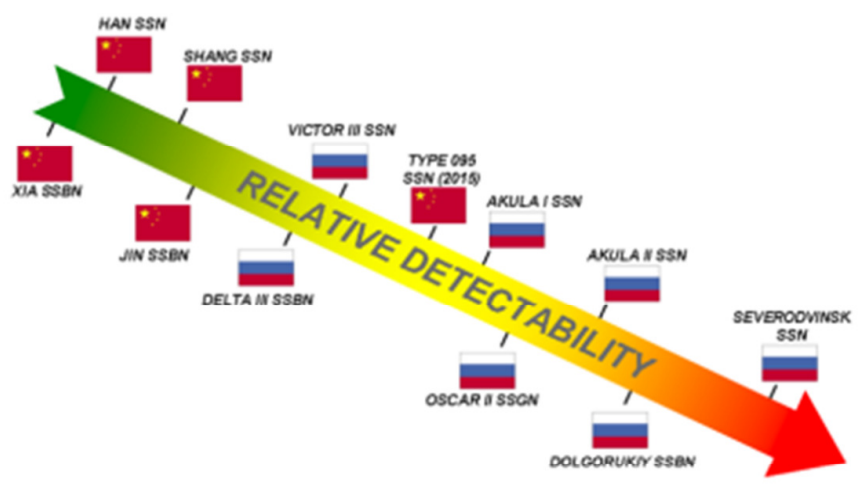

Nuclear
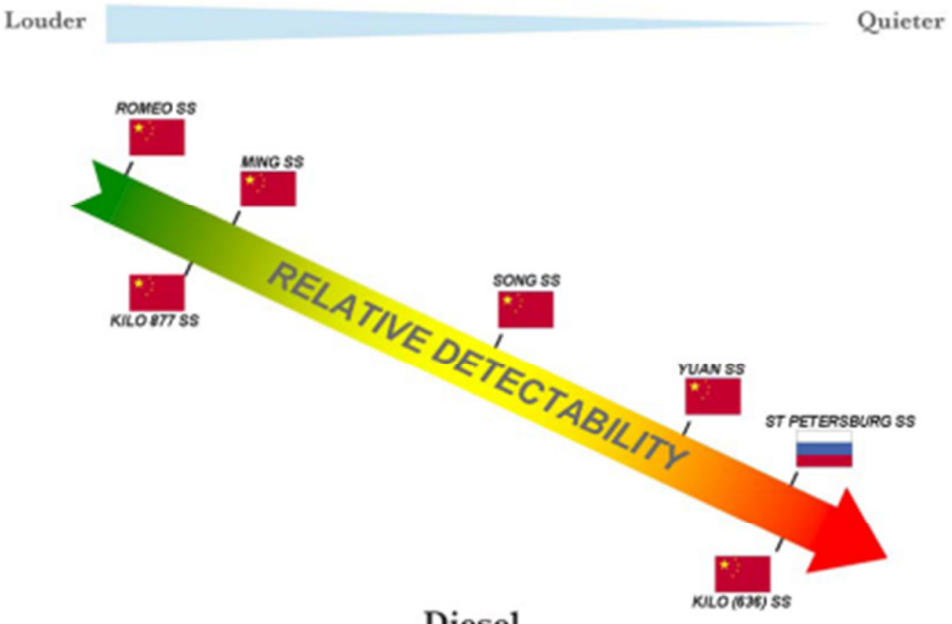

Diesel

Figure One: “The People's Liberation Army Navy: A Modern Navy with Chinese Characteristics," 22.

The possibility of a Chinese amphibious assault on Taiwan has meant that the amphibious warfare vessels of the PLAN are of real importance in an analysis of the fleet. While the number of amphibious ships in the PLAN's amphibious fleet has remained stable, the quality of the ships has improved. New classes of Landing Ship Tank (LST) and Landing Ship Medium (LSM) have replaced more vintage units, offering improved sea keeping and reliability, as well as greater endurance and troop capacity. ${ }^{193}$ However, these new ships have not significantly increased the Chinese amphibious lift capacity from one infantry division. ${ }^{194}$ The first Yuzhao-class landing platform dock (LPD) amphibious transport ship entered service in 2008. Two or three more are to be constructed,

\footnotetext{
193 Ibid., 20.

194 Yves-Heng Lim, "The Driving Forces Behind China's Naval Modernization," Comparative Strategy 30, no. 2 (2011): 108.
} 
though some reports state that a total of six will be built. While similar in appearance to the new San Antonio-class amphibious transport dock ships of the US Navy, the Yushao class displace only 17,600 tons compared to the San Antonio's 25,900 tons. Like many of China's new vessels, its design appears to incorporate stealthy design features such as clean and sloped sides. ${ }^{195}$ With a large flight deck, the Yuzhao class is ideal for humanitarian assistance missions, an important mission for the PLAN. The PLAN also has two Type 920 hospital ships which contribute to this capability. ${ }^{196}$ There are rumours that a landing helicopter dock type (LHD) ship displacing 20,000 tons will be built for the PLAN, but this has yet to be confirmed. ${ }^{197}$ The construction of an LHD by China would likely garner much attention due to LHDs having a similar appearance to an aircraft carrier.

The onshore weapons systems of the PLA are also of importance to the PLAN and Chinese naval strategy. The most obvious in this regard is the aircraft carrier killing ballistic missile, the Dong Feng 21, D variant (DF-21D). The DF-21 is a medium range ballistic missile that first entered service in 1991 and is China's principal regional nuclear missile. ${ }^{198}$ The DF-21D is properly described as an anti-ship ballistic missile (ASBM) and is thought to have a range of $1,500 \mathrm{~km} .{ }^{199}$ In order to engage enemy ships with such a weapon the target must be detected and identified, this would likely be achieved by satellite reconnaissance. This would be augmented by air or naval patrols, over the horizon radar and electronic surveillance. Satellite based radar on its own may not be sufficient, as carrier sized ships such as super tankers or cruise ships are relatively common, and the detail required from a satellite to distinguish the target can be prevented by inclement weather. ${ }^{200}$ Once a target has been identified, the missile is launched and heads on a ballistic trajectory until its manoeuvring re-entry vehicle activates, using optical and radar sensors to guide the warhead onto its target. ${ }^{201}$ On impact, the warhead will be travelling at 3,500 metres per second and will impact with a force equating to $5 \%$ of that given off by the nuclear bomb dropped on Hiroshima. On its own, the kinetic energy would do sufficient damage to a carrier size target to prevent it carrying

\footnotetext{
195 O'Rourke, China Naval Modernization: Implications for U.S. Navy Capabilities-Background and Issues for Congress, 40.

${ }^{196}$ Defense, "Military and Security Developments Involving the People's Republic of China 2011," 67.

197 Massimo Annati, "Amphibious Assault and Power Projection Platforms," Military Technology 31, no. 11 (2007); O'Rourke, China Naval Modernization: Implications for U.S. Navy Capabilities-Background and Issues for Congress, 41.

${ }^{198}$ Robert S. Norris and Hans M. Kristensen, "Chinese Nuclear Forces, 2010," Bulletin of the Atomic Scientists 66, no. 6 (2010): 135.

199 Defense, "Military and Security Developments Involving the People’s Republic of China 2011," 3.

${ }^{200}$ Nick Young, "Chinese Anti-Ship Missile Analysis Shows Us Navy Carriers at Tangible Risk," Defence IQ, accessed 28 September 2011, http://www.defenceiq.com/naval-and-maritime-defence/articles/chinese-anti-ship-missile-analysisshows-us-navy-c/.

${ }^{201}$ O'Rourke, China Naval Modernization: Implications for U.S. Navy Capabilities-Background and Issues for Congress, 10. 
DEFENSIVE REALISM AND CHINESE MARITIME STRATEGY

out additional missions (referred to as mission-kill) and the addition of $600 \mathrm{~kg}$ of explosive in the warhead may be enough to sink it. ${ }^{202}$ Whether the DF-21D can actually hit a US carrier cruising at 30 knots, at a range of $1,500 \mathrm{~km}$, has yet to be proven, but the fact that the PLA appears to have the capability to perform this task already has significant implications for navies operating within range of this system. ${ }^{203}$

The other land based systems that are of significance for PLAN strategy are aircraft. The PLAN Air Force (PLANAF) is the air arm of the Chinese navy and is responsible for maritime strike and air cover for ships at sea, as well as operating the PLAN's ship based helicopters. As well as the helicopters and combat aircraft themselves, airborne early warning and control (AEW\&C), antisubmarine warfare and tanker aircraft are also part of a total PLANAF fleet of over 800 aircraft. ${ }^{204}$ The fighter fleet comprises of the indigenously produced J-8, which entered production in 1979, but has undergone significant modernisation in the past two decades, and the Su-30 Flanker, a fourth generation multi-role fighter purchased from Russia between 1992 and $2002{ }^{205}$ The latest batch of Flankers has an extended range and the advanced AS-17 Krypton air-to-surface missiles, which together will allow it to fulfil a maritime strike and air-to-air role. ${ }^{206}$ China's maritime strike aircraft fleet has expanded and improved since 2000 when the fleet was only about $40 \mathrm{JH}-7$ fighter-bombers and H-6D bombers. The JH-7 fleet today numbers around 80 and has been upgraded to accommodate more advanced ASCM and radar systems, and the H-6D fleet has also doubled. ${ }^{207}$ Five H-6 airframes have been modified to act as tankers allowing Chinese aircraft to extend their operating ranges, and this will be complemented by eight II-76 Midas tankers ordered from Russia. ${ }^{208}$ While the aerial refuelling capability will extend the range of the PLANAF's most advanced Flankers out to $5,200 \mathrm{~km}$ with a single refuelling, most other aircraft in the fleet are not

\footnotetext{
${ }^{202}$ Young, "Chinese Anti-Ship Missile Analysis Shows Us Navy Carriers at Tangible Risk," accessed.

${ }^{203}$ O'Rourke, China Naval Modernization: Implications for U.S. Navy Capabilities-Background and Issues for Congress, 11.

${ }^{204}$ Kamlesh Kumar Agnihotri, "China's Naval Aviation and Its Prospective Role in Blue Water Capabilities of the PLA Navy," Maritime Affairs: Journal of the National Maritime Foundation of India 6, no. 2 (2010): 23.

205 "The People's Liberation Army Navy: A Modern Navy with Chinese Characteristics," 24-25; Steven Aftergood, "J-8 (Jian-8 Fighter Aircraft 8) / F-8," Federation of American Scientists, 26 June 2000, accessed 5 October 2011, http://www.fas.org/man/dod-101/sys/ac/row/j-8.htm.

${ }^{206}$ Roger Cliff, "The Development of China's Air Force Capabilities," (Santa Monica: RAND Corporation, 2010), 7; "The People's Liberation Army Navy: A Modern Navy with Chinese Characteristics," 24-25.

${ }^{207}$ Cliff, "The Development of China's Air Force Capabilities," 7.

208 "The People's Liberation Army Navy: A Modern Navy with Chinese Characteristics," 25; Bussert and Elleman, People's Liberation Army Navy: Combat Systems Technology, 1949-2010, 110; Erik Lin-Greenberg, "Offensive Airpower with Chinese Characteristics: Development, Capabilities, and Intentions," Air \& Space Power Journal 21, no. 3 (2007): 70.
} 
equipped for aerial refuelling which severely limits aircraft ranges. ${ }^{209}$ Several Y-8 (the Chinese variant of the Antonov An-12) and Ilyushin IL-76 airframes have also been modified to serve as AEW\&C aircraft, named the $\mathrm{KJ}-200$ and $\mathrm{KJ}-2000$ respectively. ${ }^{210}$ Most of the new Midas tankers and AEW\&C aircraft will be operated by the PLA Air Force (PLAAF) but will play an important role in naval air operations nonetheless. The aircraft that China relies on for maritime strike and air cover have grown in both number and sophistication, but as will be seen later in this section it is not alone in the region in taking these measures.

The most talked about item in the Chinese fleet is its new aircraft carrier. The ship, a Kuznetsovclass aircraft carrier formally named the Varyag, has been undergoing refit since 2005 and undertook its first sea trials in August 2011 before finally being handed over to the PLAN on 23 September2012. ${ }^{211}$ It has been named the Liaoning in honour of the province in which it refurbished. The ship is not in and of itself a major step up for the PLAN's capabilities, but is a powerful indicator for the future of the Chinese fleet. A US Department of Defence report states that the Liaoning will only "offer a limited operational capability" ${ }^{212}$ beyond its evaluation and training role, and this will only be achieved after several potentially costly years of training which have a high likelihood of deaths and loss of aircraft. ${ }^{213}$ What makes the Liaoning important is that it shows the Chinese' desire to have an aircraft carrier force, and the Liaoning is likely to be joined by as many as three indigenously produced carriers. ${ }^{214}$ This number makes sense as it should allow China to have a carrier at sea at all times, however the issue of enough vessels to support the operation of these carriers is a significant one for the PLAN. Nan Li and Christopher Weuve suggest that China will construct short take off but assisted recovery (STOBAR) type aircraft carriers as the PLAN's evaluation and training will have all been gained onboard Liaoning, itself a STOBAR type. The aircraft which China is producing for aircraft operations are also based on those used by Russia on its STOBAR aircraft carriers. Like the Liaoning, Chinese aircraft carrier are likely to be

\footnotetext{
${ }^{209}$ Bussert and Elleman, People's Liberation Army Navy: Combat Systems Technology, 1949-2010, 110; Lin-Greenberg, "Offensive Airpower with Chinese Characteristics: Development, Capabilities, and Intentions," 70.

${ }^{210}$ Bussert and Elleman, People's Liberation Army Navy: Combat Systems Technology, 1949-2010, 110.

211 "China's First Aircraft Carrier Enters Service," BBC News, 25 September 2012, accessed 25 September 2012, http://www.bbc.co.uk/news/world-asia-china-19710040; Tang Danlu, "China's First Aircraft Carrier Commissioned," Xinhua, 25 September 2012, accessed 2 October 2012, http://news.xinhuanet.com/english/china/201209/25/c_131871538.htm.

212 Defense, "Military and Security Developments Involving the People's Republic of China 2011," 3.

${ }^{213}$ For a discussion of the complexity of aircraft carrier operations see Gene I. Rochlin, Todd R. La Porte, and Karlene H. Roberts, "The Self-Designing High-Reliability Organization: Aircraft Carrier Flight Operations at Sea," Naval War College Review Autumn(1987): 76-90.

${ }^{214}$ Wendell Minnick, "Sea Trials Begin for Chinese Aircraft Carrier," Defence News, 9 August 2011, accessed 9 August 2011, http://www.defensenews.com/story.php?i=7350123\&c=ASI\&s=SEA; Bill Gertz, "China Begins to Build Its Own Aircraft Carrier," The Washington Times, 1 August 2011, accessed 10 October 2011, http://www.washingtontimes.com/news/2011/aug/1/china-begins-to-build-its-own-aircraft-carrier/?page=all. 48
} 
DEFENSIVE REALISM AND CHINESE MARITIME STRATEGY

medium sized and conventionally powered, which will be sufficient to launch aircraft capable of providing air cover to the fleet but with only limited surface attack capability. ${ }^{215}$ The PLAN initially sought to source aircraft for the carrier from Russia and had been negotiating the purchase of 50 Su-33 Flanker-Ds, Russia's in-service carrier jet fighter, however negotiations fell through based on China's violation of licensing on the Su-27SK. ${ }^{216}$ China is now producing its own version of the Su33 (named the J-11) which is based on Su-33s purchased from Ukraine in 2004, and this is the most likely jet fighter to operate from Chinese aircraft carriers. ${ }^{217}$ There are major concerns about the Chinese constructing aircraft carriers, and this is particularly due to the perception that the PLAN has no need for an aircraft carrier force. Japan and the USA have expressed apprehension, and the lack of transparency in Chinese military strategy and acquisitions will do nothing to alleviate these concerns. ${ }^{218}$ As this design of carrier will only serve to provide air cover for the PLAN its offensive capabilities are not as great as some would predict. It will not be as capable as U.S. aircraft carriers at projecting force and so can be seen as more defensive in nature. However the acquiring of aircraft carriers can still be seen to fall outside the strict requirement of a security seeking state in China's position, which either makes it an indication of a different strategy or, more likely, a lack of consideration of the actual strategic need for the procurement of this type of ship.

\section{Training and Professionalism}

The modernisation of the PLAN goes beyond platforms and weapon systems, with the Chinese navy also undergoing steps to improve the quality of training and professionalism. Without the ability to operate and maintain its equipment, the PLAN will not be able to become a modern force. Training has also been recognised one of the most important ways of raising combat effectiveness in peacetime. ${ }^{219}$ An improvement in the training of PLAN personnel begins with improvements in the recruitment and retention of personnel. In order to develop quality personnel the PLAN recognises a need to move away from a conscript based force, and

\footnotetext{
${ }^{215} \mathrm{Li}$ and Weuve, "China's Aircraft Carrier Ambitions: An Update," 22-23.

${ }^{216}$ O'Rourke, China Naval Modernization: Implications for U.S. Navy Capabilities-Background and Issues for Congress, 26.

${ }^{217}$ Defense, "Military and Security Developments Involving the People's Republic of China 2011," 46.

${ }^{218}$ Agence France-Presse, "Japan Calls for China to Explain Aircraft Carrier," Defence News, 13 August 2011, accessed http://www.defensenews.com/story.php?i=7374470\&c=ASI\&s=SEA; - - , "U.S. Asks China to Explain Need for Carrier," Defence News, 10 August 2011, accessed 1 August 2011, http://www.defensenews.com/story.php?i=7357523\&amp;c=SEA\&amp;s=TOP.

${ }^{219}$ Michael Kiselycznyk and Phillip C. Saunders, Civil-Military Relations in China: Assessing the Pla's Role in Elite Politics, ed. Phillip C. Saunders, vol. 2, China Strategic Perspectives (Washington, D.C.: National Defense University Press, 2010), 5 .
} 
recruitment is now geared to attract a higher quality of recruit. ${ }^{220}$ The development of a professional non-commissioned officer (NCO) corp has also been a priority over the past one and a half decades. NCOs are the backbone of a modern navy, providing leadership and technical expertise to the fleet, as well as helping to retain quality enlisted personnel. ${ }^{221} 40 \%$ of the PLAN's personnel are now NCOs, and they account for $65-80 \%$ of the enlisted personnel on board ships, a result of changes in recruitment made in 1999 that moved away from a majority conscript force. ${ }^{222}$ Officer training is also undergoing a shift, with the number of college graduates entering the service allowing the PLAN to cut things like basic literacy from the training regime, a section required when recruits came from rural peasant backgrounds. ${ }^{223} \mathrm{~A}$ programme similar to the US Reserve Officer Training Corps has also been established to expand the recruitment base of the navy. ${ }^{224}$ Senior officers are also required to undergo postgraduate study and professional military education in order to advance in rank, and a move towards assignments in joint roles as a requirement for promotion have been suggested for the near future. ${ }^{225}$ However, these improvements in training within the PLAN still leave it behind other modern navies such as Japan, Taiwan and South Korea, particularly in technical expertise. This is partially due to the diverse range of equipment, indigenous and foreign, that the PLAN operates. It is telling that even in peacetime the Chinese Navy struggles to repair its most modern Russian built combat systems. Sea time for PLAN vessels is also significantly less than other modern navies, particularly long range cruises, which are still considered note worthy events. ${ }^{226}$ Modernisation of the recruitment, retention and training within the PLAN has yet to fully come to fruition, but will continue to improve the calibre of PLAN personnel.

There has also been a generational change with the CCP and the PLA that has resulted in a more concrete division between civil and military spheres of government. For previous generations of Chinese leaders, experience in combat or roles linked to the revolutionary military were a prerequisite for high office, whereas the current leadership of the CCP and China is almost entirely civilian with no experience in military roles. This means that while previous leaders felt they had the knowledge and authority to intervene in military decision making processes, current leaders look to the military as a source of expert advice. This in turn is a role that military leaders can fulfil

\footnotetext{
220 "The People's Liberation Army Navy: A Modern Navy with Chinese Characteristics," 31.

${ }^{221}$ Bernard D. Cole, "Rightsizing the People's Liberation Army Navy: How Much Naval Force Will Beijing Deploy by 2016?," Asia Policy 4(2007): 86.

222 "The People's Liberation Army Navy: A Modern Navy with Chinese Characteristics," 31-32.

${ }^{223}$ Bussert and Elleman, People's Liberation Army Navy: Combat Systems Technology, 1949-2010, 167.

${ }^{224}$ Cole, "Rightsizing the People's Liberation Army Navy: How Much Naval Force Will Beijing Deploy by 2016 ?," 86.

${ }^{225}$ Kiselycznyk and Saunders, Civil-Military Relations in China: Assessing the Pla's Role in Elite Politics, 4 - 5.

${ }^{226}$ Bussert and Elleman, People's Liberation Army Navy: Combat Systems Technology, 1949-2010, 169 - 70. 50
} 
DEFENSIVE REALISM AND CHINESE MARITIME STRATEGY

as they have been promoted based on their competence and professional knowledge, though political reliability and connections still play a role. They also have no standing outside of the military which they can use to interfere in political matters. ${ }^{227}$ However, Nan Li states that the separation of civil and military powers may have implications for crisis management. The previous unity of political and military leadership in the form of Mao or Deng allowed swift and decisive action in crises without institutional hindrance, but recent events such as the 2001 collision of a Chinese jet and a U.S. EP-3 reconnaissance aircraft, the 2004 intrusion of a PLAN submarine into Japanese territorial waters, and the 2009 harassment of the USNS Impeccable, show that this is no longer the model which the PRC operates under. These, and other incidents, demonstrate a lack of coordination between the PLA and the Ministry of Foreign Affairs (MFA), shown by the long periods between incident and resolution or explanation. ${ }^{228}$ This division between the civil and military explains in better terms the conduct surrounding such incidents, with such actions being unintended rather than representative of the unified will of the Chinese government seeking to maximise its power.

\section{Para-Military Marine Agencies}

The PLAN is not the only organisation that the Chinese government is modernising in order to address maritime security issues. China has several maritime agencies that patrol its waters, as well as disputed territory such as the South China Sea. The State Oceanographic Administration (SOA), China Marine Surveillance (CMS), Maritime Safety Administration (MSA), Border Control Department, Fisheries Law Enforcement Command (FLEC), and Coast Guard all operate their own fleets of patrol craft and aircraft, and all of these agencies have received greater funding and modernised fleets since the 1990 s. $^{229}$ The FLEC will take delivery of five 3,000 tonne vessels in the next five years to augment its current fleet of 135 ships, which includes only nine vessels over 1,000 tonnes and a large number riverine patrol craft. While these vessels are ostensibly for fisheries patrol, some FLEC ships are equipped with machine and anti-aircraft guns. ${ }^{230}$ The US Department of Defence has characterised the growth of the FLEC and other civilian agencies and their growing role in maritime surveillance as an effort by the Chinese government to shift

\footnotetext{
${ }^{227}$ Kiselycznyk and Saunders, Civil-Military Relations in China: Assessing the Pla's Role in Elite Politics, 5 - 7.

${ }^{228}$ Nan Li, Chinese Civil-Military Relations in the Post-Deng Era: Implications for Crisis Management and Naval Modernization, China Maritime Studies (Newport: U.S. Naval War College, 2010), 22 - 23.

${ }^{229}$ Defense, "Military and Security Developments Involving the People’s Republic of China 2011," 60; James C. Bussert, "China's Phantom Fleet," Signal 66, no. 2 (2011): 43.

${ }^{230}$ Christian Le Mière, "Policing the Waves: Maritime Paramilitaries in the Asia-Pacific," Survival 53, no. 1 (2011): 136.
} 
perceptions of territorial disputes from military rivalries to a law enforcement issue. ${ }^{231}$ This would make sense in light of the increased funding for the MSA and CMS, which operate unarmed vessels that are thus less threatening to other states. These agencies are controlled by the SOA and operate in a law enforcement role, despite their safety and surveillance titles, undertaking patrols of disputed waters in the East China Sea. ${ }^{232}$ Ships of these civilian agencies, as well as fishing trawlers, are often at the centre of incidents in the South China Sea, such as the USNS Impeccable incident and the cutting of a Vietnamese survey vessels cables within Vietnamese waters in May $2011 .^{233}$ In an article by James C. Bussert, it is claimed that China also has 300,000 fishing trawlers organised into a maritime militia that can be utilised for harassment of foreign vessels. The argument that average fishermen "do not ram foreign coast guard vessels" ${ }^{234}$ is a strong one, and it is likely that the PLAN, civilian agencies, and whoever are crewing these harassing trawlers are coordinating their actions, particularly when several vessels concentrate on a single ship. The SOA operates in three regional branches that are collocated with the respective PLAN headquarters, indicative of the close ties between the two organisations. ${ }^{235}$ As the PLAN continues to grow so will these organisations, providing the Chinese government greater flexibility in their patrolling and actions in disputed waters, shifting disputes into a legal rather than military sphere, and allowing for enhanced surveillance of maritime territory.

\section{Regional Trends}

China is not the only state that is investing in the modernisation of its military forces. However China's own investment is a driver behind other states spending, and this has feed back into a security dilemma in the region. While numerous states are engaging in military modernisation, this paper will look at two states; Japan and Vietnam. Japan has had to react to the rise of China as a threat to the balance that the US has maintained in the region, and with particular suspicion, as the US has continued to engage with China. Vietnam on the other hand, has had a long standing rivalry with China, but does not have the same economic muscle as Japan to invest in its military. Both countries have maritime territorial disputes with China which have led to confrontations at sea. Japan has one of the largest and best equipped militaries in the region, though its budget never surpasses $1 \%$ of GNP and has constraints on weaponry and operations placed on it by the

\footnotetext{
${ }^{231}$ Defense, "Military and Security Developments Involving the People's Republic of China 2011," 60.

232 Le Mière, "Policing the Waves: Maritime Paramilitaries in the Asia-Pacific," 137.

233 Bussert, "China's Phantom Fleet," 43; Chris Rahman and Martin Tsamenyi, "A Strategic Perspective on Security and Naval Issues in the South China Sea," Ocean Development \& International Law 41, no. 4 (2010): 326.

234 Bussert, "China's Phantom Fleet," 44.

235 O'Rourke, China Naval Modernization: Implications for U.S. Navy Capabilities-Background and Issues for Congress, 30; Bussert and Elleman, People's Liberation Army Navy: Combat Systems Technology, 1949-2010, 92 - 93. 
DEFENSIVE REALISM AND CHINESE MARITIME STRATEGY

constitution. ${ }^{236}$ The Japanese Air Self Defence Force (JASDF) is seekeing to modernise its

interceptor fleet, and to that end, the government has made numerous enquires about purchasing the advanced F-22 Raptor air-superiority interceptor from the US. The F-22 would have given the ASDF the capability to outclass Chinese Su-27, J-10, and JF-17 fighters. However, there is currently a congressionally mandated embargo on foreign sales of the aircraft and US officials have expressed concerns about the effects on the regional balance of power of such a sale. ${ }^{237}$ In December 2011, the Japanese government settled on the purchase of 42 F-35A Joint Strike Fighters to fill the role. ${ }^{238}$ The Coast Guard has been expanded, in part, as a way to circumvent the $1 \%$ defence spending limit. This organisation now has a military role explicitly banned by its authorising legislation and has a freer set of rules around the use of force than the Japanese Self Defence Force (JSDF). As of 2005, the Coast Guard boasted a fleet of 145,000 aggregate tonnes, which equates to $60 \%$ the tonnage of the PLAN's surface fleet. By 2007 this had already increased to 237,000 aggregate tonnes. ${ }^{239}$ The Japanese Maritime Self Defence Force (JMSDF) is also to receive six new Aegis destroyers and has received two Hyūga-class helicopter destroyers. The Hyūga-class displaces 13,000 tonnes and can carry a compliment of 11 helicopters, making them ideal for anti-submarine operations and military operations other than war. ${ }^{240}$ The JMSDF also has the most advanced diesel-electric submarine fleet in the region which is consistently kept at the leading edge of technology. ${ }^{241}$ While this is only a small portion of the procurement projects currently underway by the Japanese military, it can clearly be seen that the Japanese Self Defence Force (JSDF) is modernising its forces in similar areas to the PLA, and in some cases, in response to developing Chinese capabilities.

Vietnam is another state that is undertaking a modernisation of its military forces, and there has been a particular focus of air and maritime forces. One of the interesting aspects of Vietnam's modernisation is that it relies on the same arms producer as China, namely Russia. Vietnam has committed to increase its defence budget by $70 \%$ in 2011 , a clear statement of its intent to

\footnotetext{
${ }^{236}$ George R. Packard, "The United States-Japan Security Treaty at 50: Still a Grand Bargain?," Foreign Affairs 89, no. 2 (2010): 96.

${ }^{237}$ Christopher W. Hughes, "Japan's Military Modernisation: A Quiet Japan-China Arms Race and Global Power Projection," Asia-Pacific Review 16, no. 1 (2009): 92.

${ }^{238}$ Hiroshi Hiyama, "F-35 Wins Japan Fighter Competition," Defense News, 20 December 2011, accessed 4 May 2012, http://www.defensenews.com/article/20111220/DEFSECT01/112200306/F-35-Wins-Japan-Fighter-Competition.

${ }^{239}$ Richard J. Samuels, "“New Fighting Power!” Japan's Growing Maritime Capabilities and East Asian Security," International Security 32, no. 3 (2008): 90 - 92, 95-69, 99.

${ }^{240}$ Christopher W. Hughes, "Japan's Response to China's Rise: Regional Engagement, Global Containment, Dangers of Collision," International Affairs 85, no. 4 (2009): 845.

${ }^{241}$ Toshi Yoshihara and James R. Holmes, "The Next Arms Race," The Diplomat, accessed 1 December 2011, http://apac2020.the-diplomat.com/feature/the-next-arms-race/.
} 
modernise its military. ${ }^{242}$ The purchase of six Kilo-class submarines from Russia was announced in late 2009, which will vastly increase the size and capability of the Vietnamese submarine force which currently consists only of two North Korean manufactured mini-subs. ${ }^{243}$ The Vietnamese navy has also taken delivery of two Gepard-class frigates and three Tarantul V-class corvettes (with a further seven on order), all Russian manufactured. ${ }^{244}$ Vietnam is also upgrading the capability of its air force, which, until the 1990s, was comprised of a large number of Vietnam War era aircraft. In the 2000s Vietnam added Su-27 and Su-30 aircraft to its inventory, though exact numbers are in some dispute in the literature. Richard Bitzinger states that a 2009 order will add twelve new Su-30MKKs to a current Vietnamese fleet of eight Su-27s and Su-30MKKs, while Richard Bitzinger states that the 12 Su-30MKKs will add to the nine Su-27s built in the early 1990s and 12 Su-30MKKs. ${ }^{245}$ This is by no means a complete look at the modernisation of these two states armed forces, but it is intended to show that China is not the only state in the region engaging in a modernisation of its forces. It also seeks to highlight competition in air and naval forces. The proliferation of submarines in the Asia-Pacific in particular is a trend that has been remarked upon by Sam Bateman in a 2011 article. ${ }^{246}$ So while China has the largest defence budget in the region and receives the lion's share of attention, it is not the only state expanding and upgrading its forces.

The reasons behind the expansion of the Chinese Navy and other maritime agencies is therefore a far more nuanced process than simply trying to build up forces to push the US out of the region and secure hegemony for China. The origins of China's renewed maritime focus come from factors such as the Taiwan crisis and a desire to protect the heart of its economy, its coastal regions, from possible attack. Further to this, China has identified its own security concerns through the new historic missions, with a focus on continuing economic growth through secure sea lanes. These were threats that the Chinese navy was incapable of addressing, and so it has required a major modernisation effort for the fleet. Even after decades of modernisation, the Chinese navy's fleet continues to have large numbers of ships that are obsolete technologically, and this fact will see the fleet actually reduce in size as a smaller numbers of high quality ships enter the service. The

\footnotetext{
${ }^{242}$ Felix K. Chang, "China's Naval Rise and the South China Sea: An Operational Assessment," Orbis 56, no. 1 (2012): 27.

${ }^{243}$ Richard A. Bitzinger, "A New Arms Race? Explaining Recent Southeast Asian Military Acquisitions," Contemporary Southeast Asia 32, no. 1 (2010): 59.

${ }^{244}$ Christian Le Mière, "The Return of Gunboat Diplomacy," Survival 53, no. 5 (2011): 62; Chang, "China's Naval Rise and the South China Sea: An Operational Assessment," 27.

245 Leszek Buszynski, "Rising Tensions in the South China Sea: Prospects for a Resolution of the Issue "Security Challenges 6, no. 2 (2010): 93 - 94; Bitzinger, "A New Arms Race? Explaining Recent Southeast Asian Military Acquisitions," 59.

${ }^{246}$ Sam Bateman, "Perils of the Deep: The Dangers of Submarine Proliferation in the Seas of East Asia," Asian Security 7 , no. 1 (2011). 
DEFENSIVE REALISM AND CHINESE MARITIME STRATEGY

modernisation of the PLAN is therefore necessary if the China is to have a force that can confront the security challenges that it has identified. Weapons like the anti-ship ballistic missile are a method of making up for this lack of naval capacity. The growth of China's paramilitary organisations and how these craft interact with those of other states that have competing territorial claims is one of the key concerns to arise from China's naval modernisation and will be addressed in a later section. Finally, by looking at the growth of other states militaries, it is clear that China is not the only state expanding and improving its forces. There is a security dilemma developing within Asia, and while China continues to develop its forces, and there is little reason for it to stop, it will continue to see rising defence expenditures throughout the region. 


\section{RECENT OPERATIONS}

While China has been engaging in a programme of modernisation of its navy from the 1990s and has slowly been undertaking more port visits throughout Asia, Indian Ocean, and the Pacific, it has recently ramped up its operations both in Asia and further afield. Anti-piracy operations in the Gulf of Aden were one of the first and most high profile overseas operations. The outbreak of violence in Libya in 2011 also saw the PLAN assist in evacuation of Chinese citizens. These two events drew attention to Chinese operations in a way that operations within Asia have not. However, these operations are also powerful indicators not only of the future of the Chinese navy but also the stance that China is taking as its military forces continue to grow in capability. In this chapter, the recent operations of the PLAN in the Gulf of Aden, Mediterranean, as well as the South and East China Sea, will be examined. It will look at the conduct and motives, as well as the benefits that China drew from these operations. There is a disconnect between the multilateralism and cooperation demonstrated by operations in the Gulf of Aden and the stance taken by the PLAN in its operations in the South China Sea, which are firmly cantered on maintaining its territorial claims.

\section{Gulf of Aden}

Piracy has been a developing issue in the Gulf of Aden since 2005, when three Taiwanese trawlers were captured by Somali pirates and ransomed back to the owners. ${ }^{247}$ The number of pirates operating in these waters has been on the increase ever since, and with it the number of ships that have been pirated for ransom. As well as ship owners taking action to better protect their vessels, there has also been a large and well coordinated response by the international community, authorised by the United Nations Security Council. There are two major multilateral operations taking place to protect shipping in the Gulf of Aden, that being the US led Task Force 151, and the European Union (EU) led Operation Atlantia. Under the auspices of these two groups, a large number of states have contributed warships. Other states, such as India, Russia, Iran, and China, have sent warships to the region outside of these groupings. ${ }^{248}$ The first PLAN ships were sent to the region in 2008 with the task of escorting Chinese owned shipping through the Gulf, which included shipping from Taiwan, as it is seen to be part of China. The initial task force consisted of a Luynag II-class destroyer, a Luyang I-class destroyer, and a Fuchi-class supply ship. These

\footnotetext{
${ }^{247}$ Patrick Lennox, Contemporary Piracy Off the Horn of Africa (Calgary: Canadian Defence and Foreign Affairs Institute, 2008), 9.

${ }^{248}$ James Kraska, "Coalition Strategy and the Pirates of the Gulf of Aden and the Red Sea," Comparative Strategy 28, no. 3 (2009): 200 - 2001; Shishir Upadhyaya, "Piracy in the Gulf of Aden: Naval Challenges," Maritime Affairs: Journal of the National Maritime Foundation of India 6, no. 2 (2010): 135. 
DEFENSIVE REALISM AND CHINESE MARITIME STRATEGY

represented the most modern ships in the PLAN fleet and were commanded by some of the most senior and experienced officers in the Chinese Navy. Prior to his appoint as commander of the task force, Admiral Du Jingchen had been the Chief of Staff of the South Sea Fleet. ${ }^{249}$ This tendency to assign only the most advanced ships, commanded by senior officers, after meticulous study and even rehearsals, is a reoccurring feature of overseas operations by the PLAN and has raised questions about the ability of the PLAN to conduct operations at short notice. ${ }^{250}$ Initially, the PLAN took a cautious and independent approach to the operation, to the extent that only Chinese replenishment vessels made any visits to local ports to replenish supplies, the destroyers staying at sea continuously for the three months of the operation in order to avoid raining concerns in the region (Western ships usually have a port call every $10-14$ days). ${ }^{251}$ China did not participate in information sharing or patrol coordination programmes, focusing solely on protecting Chinese flagged vessels. This changed in January 2010, when China indicated it would participate in Shared Awareness and Deconfliction (Shade) meetings as a co-chair, as well as assigning its forces to patrol a designated area of responsibility in the Gulf of Aden. By participating in Shade and moving to a patrol, rather than escort mission, China significantly changed the nature of its involvement in the anti-piracy efforts from a sole effort, to being part of a coordinated effort. ${ }^{252}$

There are several important motives behind China's initial participation and then the change in the nature of its participation in anti-piracy activities in the Gulf of Aden. The first and most obvious motive is the protection of Chinese trade transiting the region. 1,200 Chinese vessels pass through the Gulf of Aden ever year, representing one-third of China's seaborne trade. ${ }^{253}$ Protecting Chinese trade is important for the continued economic development of China, and this, as well as the collective security elements of the mission, fits neatly within the PLA's new historic missions. ${ }^{254}$ The Chinese government was also faced with the need to assuage public opinion after a fishing trawler was captured in November 2008, and a month later a tanker was attacked and only avoided capture when a Malaysian military helicopter intervened. Bloggers began expressing frustration that the PLAN, which had been presented to them as a modern and capable force, was

\footnotetext{
249 Lin-Greenberg, "Dragon Boats: Assessing China's Anti-Piracy Operations in the Gulf of Aden," 215.

${ }^{250}$ Yung et al., China's out of Area Naval Operations: Case Studies, Trajectories, Obstacles, and Potential Solutions, 34 35.

${ }^{251}$ Ibid., 17; Alexander Nicoll, "China's Three-Point Naval Strategy," IISS Strategic Comments 16, no. 37 (2010): 2.

252 Lin-Greenberg, "Dragon Boats: Assessing China's Anti-Piracy Operations in the Gulf of Aden," 219.

253 Kraska, "Coalition Strategy and the Pirates of the Gulf of Aden and the Red Sea," 201.

${ }^{254}$ Andrew S. Erickson, "Chinese Sea Power in Action: The Counterpiracy Mission in the Gulf of Aden and Beyond," in The PLA at Home and Abroad: Assessing the Operational Capabilities of China's Military, ed. Roy Kamphausen, David Lai, and Andrew Scobell (Carlisle PA: Strategic Studies Institute, United States Army War College, 2010), 296 - 97.
} 
incapable of protecting Chinese interests. ${ }^{255}$ Many authors also note the training benefits of conducting anti-piracy missions at such a great distance from the Chinese mainland, however Erik Lin-Greenberg notes that the PLAN was initially reluctant to commit forces to the operation, and participation was driven by the Ministry of Foreign Affairs (MFA). ${ }^{256}$ The interest of the MFA in the participation of Chinese forces in anti-piracy operations was likely driven by another benefit, presenting China as a responsible and engaged great power. The deployment is authorised by several United Nations Security Council Resolutions giving it legitimacy, and shows China's military in a role that serves to dispel some of the China threat assertions. ${ }^{257}$ In changing the approach from an independent operation to coordination with Shade, the Chinese government had to consider the overall effectiveness of the operation. Two warships and a replenishment ship could not hope to protect all Chinese trade. Indeed, the hijacking of another vessel, a bulk carrier in October 2009, was soon followed by Chinese moves to fully participate in Shade. ${ }^{258}$ By participating in the multilateral programme, China could now achieve its goals of waving the flag and protecting Chinese trade, without the threat that any attack on a Chinese vessel would be identified as a failure by the Chinese government.

The anti-piracy patrols undertaken by the PLAN have had several benefits, both to the organisation and to China's reputation, but it is important that authors are realistic about the type of mission that the Chinese navy is undertaking in the Gulf of Aden and what it actually tells us about the PLAN. The deployment has clearly had training benefits for the Chinese navy, any operations undertaken by naval forces do. These benefits have been in the areas of navigation, seamanship, under-way replenishment and equipment operation. ${ }^{259}$ The PLAN has been given a unique opportunity by the deployment to practice these tasks at a great distance from the mainland, without generating the negative reaction or suspicion that it would otherwise would. ${ }^{260}$ The PLAN has also used the deployment to test its most advanced indigenously produced ships, sending only these ships to the Gulf. ${ }^{261}$ It is important that these training benefits are not overstated though. The Gulf of Aden deployment is not a rehearsal for SLOC protection mission against a conventional adversary; protecting shipping against poorly armed pirates is not the same

\footnotetext{
${ }^{255}$ Lin-Greenberg, "Dragon Boats: Assessing China's Anti-Piracy Operations in the Gulf of Aden," 217; Erickson, "Chinese Sea Power in Action: The Counterpiracy Mission in the Gulf of Aden and Beyond," 298, 301.

${ }^{256}$ Lin-Greenberg, "Dragon Boats: Assessing China's Anti-Piracy Operations in the Gulf of Aden," 218.

${ }^{257}$ Yung et al., China's out of Area Naval Operations: Case Studies, Trajectories, Obstacles, and Potential Solutions, 5; Lin-Greenberg, "Dragon Boats: Assessing China's Anti-Piracy Operations in the Gulf of Aden," 219.

${ }^{258}$ Lin-Greenberg, "Dragon Boats: Assessing China's Anti-Piracy Operations in the Gulf of Aden," 219.

${ }^{259}$ Yung et al., China's out of Area Naval Operations: Case Studies, Trajectories, Obstacles, and Potential Solutions, 54 55; Lin-Greenberg, "Dragon Boats: Assessing China's Anti-Piracy Operations in the Gulf of Aden," 218.

${ }^{260}$ Lin-Greenberg, "Dragon Boats: Assessing China's Anti-Piracy Operations in the Gulf of Aden," 218.

${ }^{261}$ Erickson, "Chinese Sea Power in Action: The Counterpiracy Mission in the Gulf of Aden and Beyond," 302 - 03.
} 
DEFENSIVE REALISM AND CHINESE MARITIME STRATEGY

as protecting it against a conventional threat operating under, on and above the water. Yung et al point out that the training benefits for those ships completing the deployment comes at the cost of time that could be spent training for conventional combat operations, and so could be seen to hinder some other areas of training. ${ }^{262}$ Even replenishment at sea experience is of limited use in a scenario such as conflict with Taiwan, as the island is close enough to the mainland for this not to be needed for operations. As well as training, there are some other benefits for the PLAN. The Chinese ships almost certainly undertake some reconnaissance of other warships, however this is not in excess of what any other nation would undertake in such a setting. It has also given the PLAN experience in operating in a multilateral environment, initially operating near to other warships, and now operating in coordination with them. The only major deficiency that the deployment has shown, is the limited number of fleet replenishment ships in the Chinese fleet, which led to the need for civilian vessels to be brought in to support the operation. ${ }^{263}$ This deficiency would become more acute in combat operations, and so is an area that the PLAN will need to address if it wishes to further develop its blue-water capabilities.

\section{Libya}

One of the key unintended benefits that came from the deployment of PLAN ships to the Gulf of Aden was that the Chinese government had forces in a position to assist with the evacuation of Chinese nationals from Libya after violence broke out in the country in February 2011. The Libyan uprising was one of the first tests of the PLA's ability to respond to the needs of a Chinese population that has gone out into the world as part of China's go global strategy. ${ }^{264}$ It also represented an opportunity for the PLAN to demonstrate the developments in its capabilities since its failure to provide any support to the evacuation of Chinese nationals from Somalia in 1991. On 27 February, the Jiangkai-II class guided-missile frigate Xuzhou entered the Mediterranean after transiting the Suez Canal. The Xuzhou was in the region as part of the anti-piracy patrols in the Gulf of Aden and had recently resupplied in the port of Salalah in Oman, so was able to redeploy quickly to the Mediterranean. ${ }^{265}$ The frigate was dispatched to aid in the Chinese government's

\footnotetext{
${ }^{262}$ Yung et al., China's out of Area Naval Operations: Case Studies, Trajectories, Obstacles, and Potential Solutions, 54 55.

${ }^{263}$ Lin-Greenberg, "Dragon Boats: Assessing China's Anti-Piracy Operations in the Gulf of Aden," 224 - 26.

${ }^{264}$ Paola Bellabona and Francesca Spigarelli, "Moving from Open Door to Go Global: China Goes on the World Stage," International Journal of Chinese Culture and Management 1, no. 1 (2007): 94.

${ }^{265}$ Gabriel Collins and Andrew Erickson, "Missile Frigate Xuzhou Transits Suez Canal, to Arrive Off Libya Wednesday 2 March: China's First Operational Deployment to Mediterranean Addresses Libya's Evolving Security Situation," China Sign Post, 30 July 2011, accessed 7 December 2011, http://www.chinasignpost.com/2011/02/missile-frigate-xuzhoutransits-suez-canal-to-arrive-off-libya-wednesday-2-march-china\%E2\%80\%99s-first-operational-deployment-tomediterranean-addresses-libya\%E2\%80\%99s-evolving-security-situation/.
} 
response to the deepening crisis in Libya, which resulted in the evacuation of 35,000 Chinese nationals by chartered and military aircraft, as well as chartered merchant vessels and overland buses. ${ }^{266}$ The frigate arrived off the coast of Libya on 1 March where it took up escort on the chartered Greek ferry El. Venizelos and its 2,141 Chinese passengers, the final Chinese chartered ferry to leave Libya. The ferry was already about half way through its journey to the port of Heraklion on the island of Crete. ${ }^{267}$ After completing its escort mission, the Xuzhou then returned to continue anti-piracy patrols. It was the first ever deployment of a Chinese warship into the Mediterranean Sea, and as such, led to some alarmist media reporting and conjecture. The British newspaper The Daily Mail's online edition published an article titled, “After Beijing sends a frigate to the Med, a leading author poses a chilling question... How long until a Chinese aircraft carrier sails up the Thames?" 268

The deployment was not a harbinger of an expanded global role for the Chinese navy. It did show both a logical, though in practice largely symbolic, response by the Chinese government making the best use of PLAN assets in the region. The evacuation was conducted in a fairly permissive environment, the no fly zone and bombing campaign by NATO led forces had yet to begin, meaning that foreign warships were not yet a target and there had been no moves by the Gaddafi regime to prevent the evacuation of nationals, but China's dispatch of a warship was similar to the actions of many other states. The USA, UK, France and Canada all dispatched warships to assist in evacuations, and Russia had requested a Turkish naval escort for its own ferry chartered for evacuation. ${ }^{269}$ The Chinese government was then operating along best practise for such a situation. It was also in a historically unique position to dispatch a warship to the region. Only because there were warships conducting anti-piracy patrols in the region, were the PLAN able to provide this support, otherwise the nearest warship would have been in Asia and unable to provide support in a useful timeframe. However, the Xuzhou appears to have only been off the coast of Libya for a very short period of time and escorted only the final transport of Chinese nationals, with Chinese

\footnotetext{
${ }^{266}$ Evan A. Feigenbaum, "China's Pakistan Conundrum," Foreign Affairs, 4 December 2011, accessed 7 December 2011 , http://www.foreignaffairs.com/articles/136718/evan-a-feigenbaum/chinas-pakistan-conundrum.

267 "Chinese Navy Frigate Arrives Waters Off Libya for Escort Mission," Xinhua, 1 March 2011, accessed 8 December 2011, http://news.xinhuanet.com/english2010/china/2011-03/01/c_13756148.htm; Fu Jing, "Home Thoughts after Journey out of Danger," China Daily, 3 March 2011, accessed 8 December 2011, http://www.chinadaily.com.cn/cndy/2011-03/03/content_12106130.htm; Zhang Xiang, "Greek Ship Docks at Crete with Evacuatees from Libya," Xinhua, 2 March 2011, accessed 8 Decmber 2011, http://news.xinhuanet.com/english2010/china/2011-03/02/c_13758156.htm.

268 Ian Morris, "After Beijing Sends a Frigate to the Med, a Leading Author Poses a Chilling Question... How Long until a Chinese Aircraft Carrier Sails up the Thames?," The Daily Mail, 5 March 2011, accessed 7 December 2011, http://www.dailymail.co.uk/news/article-1363440/After-Beijing-sends-frigate-Med-leading-author-poses-chillingquestion--How-long-Chinese-aircraft-carrier-sails-Thames.html.

269 "Russia Sends Planes, Ship to Evacuate Foreigners from Riot-Struck Libya," RIA Novosti, 22 February 2011, accessed 9 December 2011, http://en.rian.ru/world/20110222/162721789.html. 
DEFENSIVE REALISM AND CHINESE MARITIME STRATEGY

chartered ferries already having made the trip from Libya to both Malta and Crete. ${ }^{270}$ Another possible motive for the dispatch of a Chinese warship, intelligence gathering, would have been of limited value in the end, due to the fact that combat operations by NATO led forces had yet to begin. The combat firing of weapons, such as the Tomahawk cruise missile and the radar and other electronic traffic that precedes it, would have been useful intelligence to gather, but the Xuzhou departed the Mediterranean long before this occurred. What the mission did provide was a clear demonstration to the Chinese public that the PLAN now had the word wide reach that they expected of their navy and that the Chinese government would use it to protect them in a time of need. Pictures of the PLAN frigate escorting the El. Venizelos, as well as those of PLAAF II-76 transport planes moving into the region, played well in domestic media. New reporting of the evacuations emphasised the unprecedented nature of the operation, the role of the military in it, as well as the leading role of the CCP in organisation at a government level and with party members on the ground. As a demonstration of China's commitment to protecting its citizens working overseas, the operation was an overwhelming success and may well set a precedent for future civilian evacuations by the PLA. Any future PLAN involvement in these operations would be dependent on the presence of Chinese warships in the vicinity, and with the Gulf of Aden mission being the only regular deployment of warships outside of its region, this leaves large areas of the globe out of range.

\section{Exercises 2010}

While China completes high profile operations in the Gulf of Aden and Mediterranean, it continues to conduct extensive exercises closer to home. All military organisations conduct such exercises, but the nature and scope of the PLAN's exercises have clearly changed since 2010. In 2009, there were no exercises by the PLAN in the Pacific and no exercises of note in the South China Sea. Some exercises were conducted with Russia as part of the anti-piracy patrols in the Gulf of Aden, but these were limited in participation to the ships that were in the area. ${ }^{271}$ This would change dramatically in 2010 when the Chinese Navy undertook a series of exercises that were unprecedented for the force. In April, a flotilla of 16 ships, consisting of units from all three of PLAN's fleets, came together for an exercise. Initially this exercise was reported as two separate exercises, however it now appears that this was a single larger exercise, and while this paper will

\footnotetext{
${ }^{270}$ Demetris Nellas, "2,800 Chinese Evacuated from Libya to Crete," The Guardian, 26 February 2011, accessed 12 December 2011, http://www.guardian.co.uk/world/feedarticle/9519422.

271 "China, Russia Hold Joint Naval Military Exercise in Gulf of Aden," Xinhua, 20 September 2009, accessed 6 June 2012, http://news.xinhuanet.com/english/2009-09/20/content_12081764.htm.
} 
address the events as a single exercise, it is important to note that some ambiguity remains. The exercise consisted of live fire exercises and confrontation drills along the Chinese coast, practising repulsing air, sea and submarine attacks launched against the flotilla. The fleet then sailed within $140 \mathrm{~km}$ of Okinawa and through the Bashi Channel which separates Taiwan and the Philippines, and visited Fiery Cross Reef in the Spratly Islands. ${ }^{272}$ It was the first time that such a large Chinese force had come so close to Japan. The exercise gained media attention when a helicopter operating from the PLAN flotilla flew within 90 metres of a JMSDF destroyer, one of two Japanese warships that began following PLAN ships as they approached Okinawa. ${ }^{273}$ The exercise was also the first time that ships from the East and North Sea Fleets had operated in the South China Sea, a powerful demonstration of China's ability to deploy forces to the region if needs be. The inclusion of ships from all three fleets may also signal that China is moving away from the current and outdated system of three independent fleets (South, East, and North) towards a central command structure. This was one of four major exercises that were conducted by the PLAN during 2010. The second was held in early July in response to the US-South Korean exercises that were themselves a response to the sinking of the Cheonan by North Korea. ${ }^{274}$ The third was a large and domestically well reported live fire exercise conducted by the majority of the modern ships in the PLAN in July. This exercise came only three days after The US made an offer to facilitate a multilateral dialogue between those claimants on territory in the South China Sea during the $17^{\text {th }}$ Association of South East Asian Nations (ASEAN) Regional Forum (ARF). ${ }^{275}$ The timing was certainly precipitous, and the organisation of the exercise to coincide with the ARF is a possibility, though three days is far too little time to organise an exercise so it was not a direct response to US moves. The fourth was an amphibious landing exercise held in November. ${ }^{276}$ These exercises showed both China's confidence in undertaking long range operations and the willingness of China to use exercises to make a political point, and the exercises undertaken in 2011 would repeat this.

\footnotetext{
272 Alexander Nicoll, "Chinese Navy's New Strategy in Action," IISS Strategic Comments 16, no. 16 (2010).

${ }^{273}$ Edward Wong, "Chinese Military Seeks to Extend Its Naval Power," The New York Times, 23 April 2010, accessed 14 December 2011, http://www.nytimes.com/2010/04/24/world/asia/24navy.html?pagewanted=all.

${ }^{274}$ Carlyle A. Thayer, "Recent Developments in the South China Sea: Grounds for Cautious Optimism," RSIS Working Paper No. 220(2010): 7.

${ }^{275}$ Chang, "China's Naval Rise and the South China Sea: An Operational Assessment," 21.

${ }^{276}$ Thayer, "Recent Developments in the South China Sea: Grounds for Cautious Optimism," 8. 


\section{Exercises 2011}

China conducted further exercises in the Pacific Ocean in 2011. A Chinese flotilla passed between the Japanese islands of Okinawa and Miyako in June, like the exercises conducted the previous year. The JSDF reported to the media on 8 June, that a total of 11 PLAN ships transited the waters around Okinawa in three groups over two days. Submarines were also believed to be accompanying the group, and the presence of a submarine rescue ship would seem to confirm this. ${ }^{277}$ There is little additional information on the nature of these exercises, except that the Chinese Ministry of National Defence stated that the exercise was to last from "mid to late June" ${ }^{278}$. Pictures of the Chinese warships were released by the JMSDF. The pictures show three Sovremenny-class ships, two Jiang Wei I and two Jiang Wei II frigates, as well as a tug, intelligence collection ship, submarine rescue ship and supply ship. ${ }^{279}$ The Japanese Defence Minister expressed concern about the passage of the vessels, as the ministry had for the 2010 exercise. ${ }^{280}$ On 18 June it was reported that China had conducted a three day military exercise in the South China Sea. The exercise came immediately after the Vietnamese Navy concluded its own live fire exercise in the South China Sea, and at a time of increased tension with other states claiming territory in the South China Sea, particularly the Philippines. ${ }^{281}$ In November 2011, the Chinese defence ministry announced that the PLAN would again conduct exercises in the Pacific, showing the PLAN's continuing growth in confidence conducting these exercises. ${ }^{282}$ It has been noted in media reports that the 2011 announcement came soon after the conclusion of a Pacific tour by President Obama, during which he and Australian Prime Minister Julia Gillard announced that the US would station marines in Australia from 2012 with involvement by Japan. The tour was seen as a restatement of the US's role as a Pacific power, reassuring the USA's allies in the region. However, such an exercise takes extensive planning and so it is unlikely that the announcement was a trigger for it.

\footnotetext{
277 "Chinese Navy Vessels Cross High Seas between Okinawa Islands," Kyodo News, 8 June 2011, accessed 19 December 2011; "Japan to Monitor Chinese Navy Vessels near Okinawa," Kyodo News, 10 June 2011, accessed 20 December 2011; "11 Chinese Naval Ships Cross High Seas between Okinawa Islands in 2 Days," Kyodo News, 9 June 2011, accessed 20 December 2011.

278 "PLA Navy to Conduct Drill in West Pacific Int'I Waters in Mid to Late June," Ministry of National Defence, The People's Republic of China, 10 June 2011, accessed 20 December 2011, http://eng.mod.gov.cn/DefenseNews/201106/10/content_4246051.htm.

${ }^{279}$ Kyle Mizokami, "The Plan's Annual Miyakojima Run, 2011," New Pacific Institute, 23 June 2011, accessed 5 June 2012, http://jsw.newpacificinstitute.org/?p=6848.

${ }^{280}$ Edward Wong, "China Navy Reaches Far, Unsettling the Region," The New York Times, accessed 15 June, http://www.nytimes.com/2011/06/15/world/asia/15china.html?_r=1\&ref=world.

${ }^{281}$ Barbara Demick, "Chinese Naval Maneuvers Seen as Warning to Vietnam," Los Angeles Time, 18 June 2011, accessed 6 June 2012, http://articles.latimes.com/2011/jun/18/world/la-fg-china-vietnam-20110618.

282 "PLA Naval Fleet to Go for Exercise in Western Pacific," Ministry of National Defence, 24 November 2011, accessed 5 June 2012, http://eng.mod.gov.cn/Press/2011-11/24/content_4318685.htm.
} 


\section{What have we learnt?}

The operations off the coast of Somalia and Libya are indicative of the operations that the Chinese Navy is likely to undertake in the medium term. The deployment of ships to the Gulf of Aden was largely driven by China's foreign ministry rather than the PLA itself. It was an operation that allowed China to be seen as a responsible actor, pulling its weight in a UN sanctioned operation. It was not controversial, and played well with domestic audiences. The operation to evacuate Chinese nationals from Libya was only possible because ships were in the region supporting antipiracy operation and was of limited practical utility but useful as another good news story for the Chinese domestic audience. Tasks like that in the Gulf of Aden are rare, and the likelihood of China maintaining ships so far from its region is unlikely to occur again in the long term. However, where there are PLAN ships in a region which suffers humanitarian disaster, or where Chinese citizens require evacuating its citizens, we can expect PLAN involvement. This is not at all different from the operations of other navies. It is too soon to state that the PLAN is now in a position to help defend China's interests in Africa. First, assuming that China would military intervene in such a situation, the distances are too vast for the PLAN to play a timely and meaningful role. The PLAN's foreign operation will therefore be limited to military operations other than war, and will be dictated by foreign policy goals and domestic factors, rather than defence needs or strategic considerations.

The past two years have been unprecedented for the PLAN in terms of exercises, and there are several important implications for both the capabilities of the Chinese Navy and Chinese foreign policy. In the area of capability, the exercises showed improvements in the ability to project force into the second island chain. China is making real strides into the second island chain, which is bordered by "the Kuril, Bonin, Mariana and Caroline Islands in the Pacific". ${ }^{283}$ The most challenging aspect of such exercises is not keeping the forces supplied, but the coordination of the deployment of submarine, surface, and air elements. The exercises show that the modernisation of the PLAN is beginning to provide it with substantially improved capabilities. However, the classes of ship that are being used in these exercises tend to be only the most modern in the PLAN fleet, which reinforces that China still has some way to come in developing a fully modern naval force, retiring outdated platforms such as the Luda class destroyers and Jianghu class frigates. The nature of the exercises concluding in the South China Sea also shows that the PLAN has the ability to reinforce its territorial claims and bring large forces into the vicinity of the important sea-lane of

\footnotetext{
${ }^{283}$ Marc Lanteigne, "China's Maritime Security and the "Malacca Dilemma"," Asian Security 4, no. 2 (2008): 147. 64
} 
DEFENSIVE REALISM AND CHINESE MARITIME STRATEGY

the Straits of Malacca. ${ }^{284}$ This links closely into the foreign policy implications and outcomes of the PLAN's exercises since 2010. Demonstrating the ability to defend China's claims on the South China Sea is a clear policy objective of many of these exercises, however there is also a backlash caused by these exercises which undermines the show of force. As the PLAN demonstrates its capabilities fully, and often provocatively, this causes other parties in the South China Sea dispute to revaluate their own defence needs in the face of Chinese capabilities, and in many cases drive them to seek assistance from the US. By exacerbating the security dilemma in the region, China comes no closer to resolving territorial disputes. Perhaps the best explanation may be that the exercises appeal to the domestic audience in China and seek to show that China is standing up for its territorial claims. The long-range aspects of the exercises are less politically sensitive in some regards. While the Japanese government have expressed concern about the proximity of Chinese warships to Okinawa, the PLAN was well within its rights to sail in those waters and the Japanese government has no legal right to complain. It also remains a fact of geography that PLAN vessels have to travel near to some other country to enter the Pacific, and Japan's southern islands form a large part of this barrier. The exercises south of Taiwan look to be part of PLAN training for a possible conflict with Taipei, but most Chinese exercises implicitly have this as a goal, so it is not extraordinary. The pace and nature of the PLAN's exercise, and in all likelihood their controversy, will continue into 2012 .

\footnotetext{
${ }^{284}$ Thayer, "Recent Developments in the South China Sea: Grounds for Cautious Optimism," 8.
} 


\section{INCIDENTS AT SEA AND THE LINK TO TERRITORIAL DISPUTES}

\section{Incidents at Sea}

The South China Sea has been a consistent area of importance for the PLAN. In order to defend its claims on the area, the Chinese navy and paramilitary maritime forces actively patrol the South China Sea, in addition to exercises in the area. While these are of a largely non-threatening nature there has been a visible shift in Chinese operations in the past four years. This shift is usually placed as starting with what is now known as the USNS Impeccable Incident. While this is certainly not the first incident of Chinese harassment of US ships or aircraft, Oriana Mastro stated in a 2011 article that the 2009 incident was the "most significant confrontation to date". ${ }^{285}$ There have been numerous other incidents following this in the South and East China Seas and between Chinese vessels and the civilian, coastguard, and military vessels of other states. It is important to note some of these incidents do not involve PLAN vessels, instead harassment of foreign vessels is undertaken by some combination of Chinese paramilitary naval forces and civilian fishing trawlers. However, as has already been stated, the commands of these forces are collocated with PLAN commands meaning that while a PLAN ship may not be present, they are not occurring without PLAN knowledge. These incidents are a major factor in Chinese maritime operations, interactions with other claimants on the South China Sea, and other disputed territories. This section of the paper will look at some of the major incidents that have taken place between Chinese and foreign ships, the implications of these incidents to relations in the region, and what these tell us about Chinese maritime strategy.

\section{Submarine Incidents}

The first incidences this paper will examine are those between US ships and Chinese submarines. These incidents pre-date the Impeccable Incident but are important in what they tell us about China's submarine forces, the acoustics of the Chinese coast line, and the resulting discussion in the USA. In October 2006 in waters near Okinawa, a Song-class submarine surfaced within torpedo firing range of the US aircraft carrier USS Kitty Hawk, having evaded detection by the carrier's protective screen. This took place while the commander of the US Pacific Fleet was making a visit to China to promote military exchanges between the two countries. ${ }^{286}$ The incident resulted in a

\footnotetext{
${ }^{285}$ Oriana Skylar Mastro, "Signaling and Military Provocation in Chinese National Security Strategy: A Closer Look at the Impeccable Incident," Journal of Strategic Studies 34, no. 2 (2011): 221.

286 "China Sub Stalked U.S. Fleet," The Washington Times, 13 November 2006, accessed 13 December 2011, http://www.washingtontimes.com/news/2006/nov/13/20061113-121539-3317r/?page=all; Bussert and Elleman, People's Liberation Army Navy: Combat Systems Technology, 1949-2010, 75. 
DEFENSIVE REALISM AND CHINESE MARITIME STRATEGY

certain amount of soul searching about the decline in US anti-submarine warfare capabilities since the end of the Cold War, as well as the rise of China's submarine forces. ${ }^{287}$ On 11 June 2009 these themes came up again when the Arleigh Burke-class destroyer USS John S. McCain's towed sonar array was run into by a Chinese submarine in the South China Sea. ${ }^{288}$ These submarine encounters demonstrate advances in the capability and number of some Chinese submarines. However, any submarine operating within the first island chain is difficult to detect due to the shallowness of the waters, which means that sound waves created by the submarines cannot travel as far. ${ }^{289}$ This geographic advantage to submarines may lessen the accomplishment of China's submarines in these two instances. Such incidents may actually become more common place with an increase in both US and Chinese naval activity likely in the coming years.

\section{Impeccable Incident}

The Impeccable Incident is interesting not only for the confrontation itself but also for the different interpretations of the United Nations Convention on the Law of the Sea (UNCLOS) that led to it. The ship USNS Impeccable is a US ocean surveillance ship operated by the Military Sealift Command under its Special Missions Programme. It is unarmed and manned by a civilian crew. ${ }^{290}$ The USNS Impeccable is a platform for the Surveillance Towed Array Sensor System (SURTASS) with a Low Frequency Active (LFA) add-on. These systems are designed to detect quiet diesel and nuclear submarines, and are particularly effective in littoral environments where the detection of submarines becomes more difficult. ${ }^{291}$ The incident occurred on 8 March 2009, in the South China Sea, seventy-five miles south of China's Hainan Island. ${ }^{292}$ It involved five Chinese vessels: a Navy intelligence collection ship, a SOA patrol vessel, a Bureau of Maritime fisheries patrol vessels, and two Chinese flagged trawlers. ${ }^{293}$ The two trawlers manoeuvred aggressively and in close proximity to the US vessel, at one point blocking the ships path and forcing it make evasive manoeuvres to avoid a collision. The trawlers also attempted to snare the towed array of the Impeccable. The crew of the Impeccable eventually resorted to the use of fire hoses when one of the trawlers came

\footnotetext{
${ }^{287}$ Mackenzie Eaglen and Jon Rodeback, "Submarine Arms Race in the Pacific: The Chinese Challenge to U.S. Undersea Supremacy," Backgrounder, no. 2367 (2 February 2010).

${ }^{288}$ Buszynski, "Rising Tensions in the South China Sea: Prospects for a Resolution of the Issue ": 93; Eaglen and Rodeback, "Submarine Arms Race in the Pacific: The Chinese Challenge to U.S. Undersea Supremacy."

${ }^{289}$ Cote, "Assessing the Undersea Balance between the U.S. And China," accessed.

${ }^{290}$ Sam Bateman, "Clashes at Sea: When Chinese Vessels Harass Us Ships," RSIS Commentaries, no. 27 (2009), https://dr.ntu.edu.sg/bitstream/handle/10220/6093/RSIS0272009.pdf?sequence=1.

291 "Ships, Sensors, and Weapons: Undersea Warfare Programs Target an Expeditionary Future," Undersea Warfare, 2001, accessed 4 January 2012, http://www.navy.mil/navydata/cno/n87/usw/issue_11/ship_sensors_weapons.html. ${ }^{292}$ Raul Pedrozo, "Close Encounters at Sea: The Usns Impeccable Incident," Naval War College Review 62, no. 3 (2009): 101.

293 James Kraska, "Sovereignty at Sea," Survival 51, no. 3 (2009): 13.
} 
within sixteen metres, but this failed to deter the Chinese sailors who then stripped to their underwear and brought their vessels as close as eight meters to the US ship. ${ }^{294}$ This went on for two hours until the Impeccable was able to leave the area. The destroyer USS Chung-Hoon was then sent to escort the vessel and the Impeccable was able to resume its activities the next day with the Chung-Hoon providing protection. ${ }^{295}$ The confrontation was the climax of a series of actions to harass the US vessel, including low altitude flyovers, shining of spotlights, crossing close in front of the vessel at night, and bridge-to-bridge calls which stated that the Impeccable's operations were illegal and that it had to "leave the area or 'suffer the consequences". ${ }^{296}$ Before discussing the legal arguments on both sides of the incident, it is important to note that the actions of the Chinese trawlers violate numerous laws of navigation at sea and put both their own lives, and those of the sailors on the Impeccable, at risk.

China insists that the USNS Impeccable was undertaking actions that violated international law. Chinese officials insist that the vessel was within Chinese waters and that it was engaged in spying. A former vice-commander of the PLAN, Vice-Admiral Jin Mao, insisted that "The Chinese ships were exercising their legal rights," and that there was "nothing wrong" with the response of the Chinese ships. ${ }^{297}$ U.S. officials on the other hand, state that the Impeccable "was conducting routine operations in international waters." ${ }^{298}$ Both sides site UNCLOS as proof that they are in the right, though the Chinese also site domestic law, and to some degree, both are disingenuous in their claims. The US claims that its vessel was in international waters, however there is no such thing as international waters under UNCLOS. As Mark Valencia points out according to UNCLOS:

"there are internal waters, territorial waters, the exclusive economic zone and the high seas, each with their own regime regarding freedom of navigation. "International waters" is a term used by the US Navy to indicate areas where it thinks it has unconstrained navigational freedom." 299

\footnotetext{
${ }^{294}$ Pedrozo, "Close Encounters at Sea: The Usns Impeccable Incident," 101; Michael S. Chase, "Chinese Suspicion and Us Intentions," Survival 53, no. 3 (2011): 140 - 41; Kraska, "Sovereignty at Sea," 13.

${ }^{295}$ Mastro, "Signaling and Military Provocation in Chinese National Security Strategy: A Closer Look at the Impeccable Incident," 220 - 21.

${ }^{296}$ Mark Valencia, "The Impeccable Incident: Truth and Consequences," China Security 5, no. 2 (2009): 22 - 23.

${ }^{297}$ Cui Xiaohuo and Zhang Haizhou, "Top Military Officers Lash out at Us Espionage," China Daily, 11 March 2009, accessed 4 January 2012, http://www.chinadaily.com.cn/china/2009-03/11/content_7565312.htm.

298 "Chinese Ships 'Harass' U.S. Vessel," BBC News, 9 March 2009, accessed 4 January 2012, http://news.bbc.co.uk/2/hi/7933171.stm.

${ }^{299}$ Valencia, "The Impeccable Incident: Truth and Consequences," 23.

68
} 
DEFENSIVE REALISM AND CHINESE MARITIME STRATEGY

Furthermore, the US is still to ratify the convention, although it does recognise most of UNCLOS as binding customary law. ${ }^{300}$ The Chinese arguments that the US vessel was violating international law is also incorrect as there are protections within UNCLOS that allow military vessels to conduct exercises in another states exclusive economic zone (EEZ), including intelligence gathering. ${ }^{301} \mathrm{An}$ article by Ji Guoxing on the incident, a flawed piece which tries to apply territorial water rights to China's EEZ among other errors, also tries to argue hypocrisy on the part of the US, as the US would not allow intelligence collection in its own EEZ. ${ }^{302}$ However China does conduct intelligence gathering activities in the EEZ of other countries, including US Pacific territories, making such claims moot. Furthermore, claims that the Impeccable was violating Chinese domestic law also fall flat due to the fact that Impeccable is a military vessel and therefore has sovereign immunity. ${ }^{303}$ However, China maintains its own view of how the freedom of the seas operates in areas that it lays claim to, and whether they are legal or not, these need to be understood.

China's interpretation of UNCLOS gives coastal states greater control over activities within its EEZ than the interpretation of the US and other states, creating a fundamental difference between the US and China. In the US interpretation, the EEZ does not belong to the coastal state, but is an area where the coastal state has "sovereign rights and jurisdictions for economic purposes and all states enjoy high seas freedoms". ${ }^{304}$ China, as well as Brazil, India, Malaysia, Uruguay and Pakistan, have all issued declarations that UNCLOS does not authorise states to conduct military exercises in an EEZ without permission of the coastal state. ${ }^{305}$ China declared, as part of its ratification of UNCLOS in 1996, that the PRC has "sovereign rights and jurisdiction" over its EEZ. In June 2009 this was further clarified, as the Chinese Ministry of Foreign Affairs stated that it was an offence under international and domestic law for military vessels to enter China's EEZ without China's permission. ${ }^{306}$ Such a claim hinges on an interpretation of UNCLOS that is at odds with the convention and its negotiating history, but this remains China's interpretation and so is important

\footnotetext{
300 Ibid.

${ }^{301}$ Patrick J. Neher, Raul A. Pedrozo, and J. Ashley Roach, "In Defence of High Seas Freedoms," RSIS Commentaries, no. 31 (2009), http://dr.ntu.edu.sg/bitstream/handle/10220/6075/RSIS0312009.pdf?sequence=1.

302 Ji Guoxing, "The Legality of The "Impeccable Incident"," China Security 5, no. 2 (2009): 20.

${ }^{303}$ Neher, Pedrozo, and Roach, "In Defence of High Seas Freedoms."

${ }^{304}$ Brian Wilson, "An Avoidable Maritime Conflict: Disputes Regarding Military Activities in the Exclusive Economic Zone," Journal of Maritime Law and Commerce 41, no. 3 (2010): 427.

305 Jon M. Van Dyke, "Military Ships and Planes Operating in the Exclusive Economic Zone of Another Country," Marine Policy 28, no. 1 (2004): 29 - 39.

${ }^{306}$ Wilson, "An Avoidable Maritime Conflict: Disputes Regarding Military Activities in the Exclusive Economic Zone," 428 - 29.
} 
for understanding incidents at sea within China's claimed EEZ. ${ }^{307}$ What is more, it is the policy of the US government to operationally challenge such claims and interpretations of freedom of the seas under the Freedom of Navigation Programme, and so US Navy vessels will continue to operate within China's EEZ. ${ }^{308}$ China attempts to avoid claims of hypocrisy in its own naval conduct because while it conducts military activities inside the claimed EEZ's of other states, it claims much of this territory as its own. However, this argument that China abides by its own interpretation can be seen to be false through Chinese collection of intelligence from within the EEZ of US territories. ${ }^{309}$ This differing interpretation will continue to be a matter of friction, particularly between the US and China, and is further exacerbated by competing and overlapping territorial claims made by China and it neighbours.

\section{Harassment of Vietnamese and Philippine Vessels}

The relationship between China and Vietnam has been in decline as the two states compete over their respective claims in the South China Sea. This heightened dispute can be traced to Vietnamese efforts to develop offshore oil and gas resources beginning in the mid 2000s, efforts which China opposes as they take place in disputed waters. ${ }^{310}$ On 26 May 2011, three Chinese maritime surveillance vessels approached, blocked and threatened a PetroVietnam vessel which was undertaking seismic surveys 116 miles off the Vietnamese coast. One of the Chinese vessels then cut the exploration cables of the Vietnamese vessel, halting operations as the ship was repaired. China claimed that the exploration was occurring in an area under its management, and the Vietnamese claim it was occurring in an area neither under Chinese management nor under disputed claim. ${ }^{311}$ Two weeks later a Vietnamese exploration vessel was harassed by a Chinese vessel again, this coming at the same time as Vietnamese protests over Chinese threats against its fisherman operating near the disputed Spratly Islands. ${ }^{312}$ China has also maintained a policy of issuing diplomatic protests against Vietnamese attempts to develop offshore oil and gas fields, issuing eighteen objections in 2006 and 2007. ${ }^{313}$ Fishing and oil exploration ships from the Philippines have received similar treatment from Chinese vessels in the South China Sea. Manilia

\footnotetext{
${ }^{307}$ Van Dyke, "Military Ships and Planes Operating in the Exclusive Economic Zone of Another Country," 31.

${ }^{308}$ Pedrozo, "Close Encounters at Sea: The Usns Impeccable Incident," 102 - 03.

${ }^{309}$ Guoxing, "The Legality of The "Impeccable Incident"," 19 - 20.

${ }^{310}$ M. Taylor Fravel, "China's Strategy in the South China Sea," Contemporary Southeast Asia 33, no. 3 (2011): 301.

311 "China Violates Sovereignty," Vietnam News, 30 May 2011, accessed 5 January 2012, http://vietnamnews.vnanet.vn/Politics-Laws/211778/China-violates-sovereignty.html.

312 "Vietnam Says Chinese Boat Harassed Survey Ship; China Disputes," Bloomberg News, 10 June 2011, accessed 5 January 2012, http://www.bloomberg.com/news/2011-06-05/china-reassures-its-neighbors-after-clashes-overclaims-in-south-china-sea.html.

${ }^{313}$ Fravel, "China's Strategy in the South China Sea," 301 - 02. 
DEFENSIVE REALISM AND CHINESE MARITIME STRATEGY

accused Chinese forces of intruding into its territory six times between February and June 2011, and firing shots on one of these occasions. ${ }^{314}$ Chinese aircraft have buzzed Filipino fishing vessels, and Chinese fishing vessels have been chased from Philippine controlled waters by Philippine warships. Like Vietnam, the Philippines has reacted to these incidents by increasing its defence budget, with a particular focus on its navy and air force. ${ }^{315}$ These actions by Chinese vessels, particularly PLAN ships, are part of the increasingly assertive actions by China in the South China Sea. Coupled with Chinese diplomacy that insists negotiations on territorial disputes be conducted only bilaterally, these actions have raised concerns throughout the region.

\section{China's South China Sea Dispute}

The leading area of friction between China, its neighbours, and Asia's leading power, the USA, is its claims in the South China Sea. Parts of the South China Sea are claimed by the People's Republic of China, the Republic of China, Indonesia, Malaysia, Brunei, Vietnam and the Philippines. ${ }^{316}$ The PRCs claim to the South China Sea is by far the most extensive and encompasses almost the entirety of the sea. The claim was first delineated by the now infamous 'nine dashed line' on a map produced by the Kuomintang Government in 1947. There is still some uncertainty as to whether China claims all the territory within this line or if it claims all the islands with the line, and the territorial sea and EEZ that would be attached to these. A claim based on the islands would include much, but not all of the area within the nine dashed line. ${ }^{317}$ China bases its territorial claim on historic grounds which they claim reach back over two thousand years. ${ }^{318}$ By this account, the Chinese claim was first established by an expedition sent to the region of the Spratlys in 110 AD. From the 12th to 17th century occasional references were made to the islands in historic records, however establishing an actual historic claim to the island is confused by the Confucian tradition of expressing territory through "zones of influence rather than definite linear boundaries". ${ }^{319}$ While China has maintained its claim to the territory since 1947, it was formalised in 1992 by China's Law

\footnotetext{
314 Jim Gomez, "China Warns Neighbors: Stop Oil Search in Spratlys," Bloomberg Businessweek, 9 June 2011, accessed 5 January 2012, http://www.businessweek.com/ap/financialnews/D9NOD2LG1.htm.

${ }^{315}$ Koh Swee Lean Collin, "The Philippines' Navy Challenge," The Diplomat, 27 December 2011, accessed 4 January 2012, http://the-diplomat.com/flashpoints-blog/2011/12/27/the-philippines\%E2\%80\%99-navy-challenge/.

${ }^{316}$ Cole, The Great Wall at Sea, 25.

${ }^{317}$ Michael D. Swaine and M. Taylor Fravel, "China's Assertive Behavior-Part Two: The Maritime Periphery," China Leadership Monitor, no. 35 (2011): 3 - 4.

${ }^{318}$ For the full Chinese historical argument see Teh-Kuang Chang, "China's Claim of Sovereignty over Spratly and Paracel Islands: A Historical and Legal Perspective," Case Western Reserve Journal of International Law 23, no. 1 (1991). 319 Joshua P. Rowan, "The U.S.-Japan Security Alliance, Asean, and the South China Sea Dispute," Asian Survey 45, no. 3 (2005): 426.
} 
on the Territorial Sea and Contiguous Zone. ${ }^{320}$ Islands in the South China Sea are occupied by the PRC, ROC, Philippines, Vietnam and Malaysia, and some states have also built structures on reefs that are submerged at high tide, or at all times, despite these points having no associated claim to territory under UNCLOS. ${ }^{321}$ China has fought over its claims in the past, with a 1988 engagement between South Vietnamese and Chinese naval forces near the Spratly Islands resulting in the deaths of 70 Vietnamese sailors. China then occupied and militarised reefs in the island group. ${ }^{322}$

China's claim on the South China Sea again show its differing view of UNCLOS, though in this case China stands on its own with views that are at odds with any other treaty member. The method in which China wishes to address the competing claims seeks to make the best use of China's dominant position over the other claimants. China insists that all discussions over the future of the South China Sea be conducted bilaterally and outside of the dispute resolution process outlined by UNCLOS. ${ }^{323}$ Any moves by other claimants or outside parties such as the USA or the Association of South East Asian Nations (ASEAN) to internationalise and multilateralise the dispute have been dismissed by Chinese officials. The vice-foreign minister of China has stated that the US should stay out of the dispute as it is not a claimant state. This was in response to US Secretary of State Hilary Clinton's statement that the US has a "national interest" in the South China Sea, and offered to facilitate talks between the claimants. ${ }^{324}$ China has offered to suspend claims on the South China Sea and undertake joint development of hydrocarbon resources. Other claimant states have rejected this offer, as within joint development is an implicit acknowledgement that China has a legitimate claim on that territory. ${ }^{325}$ There have been two agreements signed on the dispute between China and ASEAN members, the November 2002 Declaration on the Conduct of Parties in the South China Sea, and the July 2011 Implementation Guidelines. These agreements are intended to build towards a legally binding code of conduct for the parties in the dispute built upon initial self-restraint. While there have been no new occupations of islands and reefs under dispute, there continues to be reinforcement of those areas already under occupation, and states continue to take unilateral measures to strengthen their hand in the dispute. ${ }^{326}$

\footnotetext{
${ }^{320}$ Toshi Yoshihara and James R. Holmes, Red Star over the Pacific: China's Rise and the Challenge to U.S. Maritime Strategy (Annapolis: Naval Institute Press, 2010), 88.

${ }^{321}$ Cole, The Great Wall at Sea, 24 - 25, 27 - 28.

${ }^{322}$ Rowan, "The U.S.-Japan Security Alliance, Asean, and the South China Sea Dispute," 425; Cole, The Great Wall at Sea, 28.

${ }^{323}$ Fravel, "China's Strategy in the South China Sea," 300.

${ }^{324}$ Edward Wong, "Beijing Warns U.S. About South China Sea Disputes," New York Times, 22 June 2011, accessed 16 January 2012, http://www.nytimes.com/2011/06/23/world/asia/23china.html?_r=2\&ref=world.

${ }^{325}$ Mark J. Valencia, "The South China Sea: Back to the Future," Global Asia 5, no. 4 (2010): 13.

${ }^{326}$ Sarah Raine, "Beijing's South China Sea Debate," Survival 53, no. 5 (2011): 70.
} 
DEFENSIVE REALISM AND CHINESE MARITIME STRATEGY

It is clear that China is heavily invested in its claims in the South China Sea, as are the other claimants. There are a number of factors that make the South China Sea such a valuable area to the claimants generally, and China specifically. One of the most sited factors in the dispute is the presence of hydrocarbon deposits in the South China Sea. For all the claimant states the revenue that would come from oil and gas deposits would be welcome, and for China it would help alleviate the need for importing oil and gas from other areas through waterways like the Straits of Malacca which it feels can easily be closed by outside actors. ${ }^{327}$ Interestingly, a 2011 article by Nick Owen and Clive Schofield has challenged the existing assumption that the South China Sea is a rich source of hydrocarbon, stating that reserves of oil in the region do not offer significant changes to regional energy security, though natural gas reserves could extend the regions supplies through the medium to long term. Nevertheless, any reserves will likely be fiercely contested regardless of their size. ${ }^{328}$ Fisheries are another area of importance in the dispute for control of islands in the South China Sea. China's claim to the area would give it control of the fisheries in the EEZ that comes with them. ${ }^{329}$ The area is also a vital shipping lane for China, and this importance links into China's worries about the Straits of Malacca. Chinese control of the South China Sea would push China's territory into a strategically advantageous proximity to the Strait, and developing the islands in the sea could aid in Chinese power projection to prevent any closing of that vital sea lane. ${ }^{330}$ The other consideration for Chinese policy makers in the South China Sea is nationalist sentiment within China. The Chinese public is continuously told of China's return to the status of a great power and the modernisation of its military forces. This has fed into powerful nationalist sentiment which wishes to see issues such as the Taiwan, the South China Sea and other territorial disputes settled in China's favour. As the stability and survival of CCP rule in China is the primary focus of the Chinese leadership and the military, this is no minor factor in Chinese actions. And not only are the public nationalistic, but so are the foreign policy makers themselves. ${ }^{331}$ As a matter of territorial and economic importance, as well as importance to regime stability and survival through the impact of public sentiment, the South China Sea is a vital area for China and this importance informs the attitude of Chinese foreign policy makers.

\footnotetext{
${ }^{327}$ Lanteigne, "China's Maritime Security and the "Malacca Dilemma", " 143.

${ }^{328}$ Nick A. Owen and Clive H. Schofield, "Disputed South China Sea Hydrocarbons in Perspective," Marine Policy 36, no. 3 (2012): $809-10,20-21$.

${ }^{329}$ Li Mingjiang, "Security in the South China Sea: China's Balancing Act and New Regional Dynamics," RSIS Working Paper 149(2008): 4.

${ }^{330}$ Raine, "Beijing's South China Sea Debate," 72 - 73.

${ }^{331}$ Lundquist, "Nationalism, History \& Policy," accessed.
} 


\section{Japan and the Senkaku Islands}

China also has ongoing territorial disputes with South Korea and Japan, though these disputes are conducted with a tact that differs to that seen in the South China Sea. The most notable incident between China and Japan in territorial disputes is the collision of a Chinese fishing vessel and Japanese coast guard vessels near the disputed Senkaku Islands, known as the Diaoyu Islands in China, in 2010. The Chinese vessel rammed into a coastguard vessel after it failed to respond to demands by two Japanese Coast Guard vessels that it leave what Japan claims as its territory. ${ }^{332}$ The vessel was escorted to Okinawa and the captain was arrested and prosecuted for the collision, while the crew was released and flown back to China. The incident resulted in fierce reprimands from Chinese officials and public protests in China, and the Chinese government went as far as halting exports of rare-earth minerals to Japan and arresting three Japanese nationals accused of entering a military zone until the dispute was resolved. ${ }^{333}$ In the end, the captain of the vessel was released in an apparent back down by the Japanese government and in the face of right-wing protestors who wished to see a stronger stand against China. While this particular incident may not have been a coordinated challenge like the Impeccable incident, subsequent incidents in the area have involved Chinese military aircraft and vessels. Two Chinese $Y-8$ aircraft came within $50 \mathrm{~km}$ of the islands on 2 March 2011. The Japanese Defence Ministry reported that one of the Y8s was an 'intelligence' variant and the other an antisubmarine patrol variant, and F-15 jets were scrambled in response. ${ }^{334}$ Since that event there have been 11 reported instances of Chinese vessels that have approached the Senkaku Islands but did not enter Japanese territorial waters, and one occasion in August 2011 in which Chinese fishery patrol vessels entered Japanese territorial waters briefly. ${ }^{335}$ This testing of Japanese resolve and challenging their claim to the islands is similar to the what China is undertaking in the South China Sea, with the one caveat that the strength of the JSDF ensures that China cannot use intimidation or confrontation in the same way as with the Philippines or Vietnam.

\footnotetext{
${ }^{332}$ Yoree Koh, "Maritime Collision Fuels China-Japan Tension," Wall Street Journal, 8 September 2010, accessed 6 January 2012.

${ }^{333}$ Gavan McCormack, "Small Islands - Big Problem: Senkaku/Diaoyu and the Weight of History and Geography in China-Japan Relations," Japan Focus, 3 January 2011, accessed 5 January 2012, http://japanfocus.org/-GavanMcCormack/3464.

${ }^{334}$ Associated Press, "Japanese Jets Scramble against Chinese Planes near Senkakus," Breitbart, 2 March 2011, accessed 5 January 2012, http://www.breitbart.com/article.php?id=D9LN57T80\&show_article=1.

335 "Chinese Patrol Boats Enter Japanese Waters Off Senkaku Islands," Kyodo News, 24 August 2011, accessed 10 January 2012. 


\section{South Korea}

The disputes between South Korea and China involve undersea rocks, despite the fact that UNCLOS states that no state can claim an undersea rock. The first rock is known variously as the Socotra rock, Leodo in Korean, and Suyan Rock in China. China and South Korea claim possession of the rock as they believe it lies within their EEZ. South Korea completed construction of a scientific research station on the rock in 2003 which resulted in protests from Chinese officials, however the Chinese protests did not refer to any claim of its own. ${ }^{336}$ The issue between China and South Korea came up again in July 2011 when South Korean workers began efforts to raise a bulk carrier that sunk near the rock three months earlier. Chinese patrol vessels entered the area to try to halt work but left when South Korean Coast Guard ships approached, and Chinese airplanes have also conducted surveillance patrols over the facility. ${ }^{337}$ China and South Korea also have claims on the Gageo (Korean) or Rixiang (China) Reef. On 13 December 2011 Chinese media stated that a maritime surveillance vessel was being sent to patrol the area near the reef, as well as the Socotra Rock. ${ }^{338}$ This came only days after the captain of a Chinese vessel illegally fishing in South Korean waters stabbed two South Korean coastguardsmen who were attempting to seize the vessel. One of the coastguardsmen died as a result of his injuries and this lead to diplomatic protests by South Korea, as well as public outrage. South Korea seized over 490 Chinese vessels in 2011 as a result of illegal fishing, and clashes between South Korean authorities and the fisherman can often be violent. ${ }^{339}$ While not part of the territorial dispute, it has not helped the relationship between the two countries. However, the most limiting factor in resolving this dispute is that China has not specified the area that it claims in the East China Sea. South Korea uses an

\footnotetext{
${ }^{336}$ Nengye Liu, "Law on Island Protection of People's Republic of China," Environmental Law Network International Review 2(2010); "Leodo Ocean Research Station: History of Construction," Korea Hydrographic and Oceanographic Administration, accessed 18 January 2012, http://ieodo.khoa.go.kr/eng/open_content/introduce/history.asp.

${ }^{337}$ Mark J. Valencia, "The East China Sea Dispute: Context, Claims, Issues, and Possible Solutions," Asian Perspective 31, no. 1 (2007): 134; "China Demands S. Korea Stop Hoisting Sunken Ship near leodo," Yonhap News Agency, 27 July 2011, accessed 18 January 2012, http://english.yonhapnews.co.kr/national/2011/07/27/19/0301000000AEN20110727006300315F.HTML.

338 "China Dispatches Largest Patrol Ship to East China Sea," The Telegraph, 14 December 2012, accessed 19 January 2012, http://www.telegraph.co.uk/news/worldnews/asia/china/8955066/China-dispatches-largest-patrol-ship-toEast-China-Sea.html; Yang Lina, "China Sends Leading Patrol Ship to East China Sea on Maiden Voyage," Xiahua, 13 December 2011, accessed 19 January 2012, http://news.xinhuanet.com/english/china/2011-12/13/c_131304219.htm. 339 "Chinese Fishermen 'Stab South Korean Coast Guards'," BBC News, 12 December 2011, accessed 13 December 2011, http://www.bbc.co.uk/news/world-asia-16134647; Se Young Lee, "Seoul Beefs up Steps to Fight Illegal Fishing," The Wall Street Journal, 27 December 2011, accessed 19 January 2012, http://online.wsj.com/article/SB10001424052970203391104577122010640638178.html; Jonathan Watts, "South Korean Coastguard Stabbed to Death While Seizing Chinese Boat," The Guardian, 12 December 2011, accessed 19 January 2012, http://www.guardian.co.uk/environment/2011/dec/12/south-korean-coastguard-stabbed-boat.
} 
equidistant line to define its claim in the seas between itself and China. ${ }^{340}$ Until China makes clear its claim, there cannot be a settling of this dispute.

\section{Japan, South Korea and China}

The disputes between China, South Korea and Japan are informative for China's other disputes due to the very different nature of the conduct of these disputes. While there have been violent incidents in both cases, these have been unlike the coordinated incidents that have occurred in the South China Sea. Where Chinese military vessels or aircraft have moved into disputed territory that are under the control of either Japan or South Korea, it appears that these units leave soon after being challenged by the controlling states armed forces. This is likely due to the fact the China does not enjoy the preponderance of power over South Korea and Japan than it does over its western neighbours, and so cannot violate these countries sovereignty with impunity. In both the South and East China Sea the prospect for a resolution for territorial disputes looks unlikely in anything but the long term. As already stated, nationalism has a large part to play in China's territorial claims and has led to a situation where compromise is unacceptable to nationalist public sentiment, and where those responsible with forming Chinese strategy share that sentiment. ${ }^{341}$

\section{So why now?}

It is clear that China has been active in the maritime territory that it claims, particularly in the South China Sea. However the singular question remains why, starting with the Impeccable Incident, has China become so much more assertive in its territorial claims? It is likely that rather than being part of the same strategy, China's actions against US military vessels and other claimants to territory are results of two separate motives. From a Chinese perspective, China has a legitimate claim to areas such as the Senkaku Islands and the South China Sea. A motive for the more active and confrontational approach to its claims, particularly in the South China Sea, is that China's ratification of UNCLOS in 1996 has made such assertions of jurisdiction necessary to maintain a strong claim to the territory. ${ }^{342}$ Any move by other claimants to assert control of territory in the South China Sea must be visibly opposed by China, and this includes exploring for hydrocarbons which implies ownership of the territory involved. Large and active paramilitary maritime organisations help to assert that, but at the cost of antagonising other claimants. The appearance of heightened Chinese activity, particularly in halting exploration for hydrocarbons,

\footnotetext{
${ }^{340}$ Valencia, "The East China Sea Dispute: Context, Claims, Issues, and Possible Solutions," 145 - 46.

${ }^{341}$ Thomas J. Christensen, "The Advantages of an Assertive China: Responding to Beijing's Abrasive Diplomacy," Foreign Affairs 90, no. 2 (2011): 54; Lundquist, "Nationalism, History \& Policy," accessed.

342 Fravel, "China's Strategy in the South China Sea," 299 - 300. 76
} 
DEFENSIVE REALISM AND CHINESE MARITIME STRATEGY

may be a combination of a need to assert jurisdiction and increasing activity by other states. As China moves to assert control, so other claimants react, taking their own actions to assert sovereignty and the ability to defend what is perceived as their territory. We have seen that a security dilemma is underway in Asia in terms of the modernising of military forces, and this same process will drive competition in territorial claims. China's active and aggressive stance in asserting claims to territory, particularly in the South China Sea, can therefore be put down to the results of the ratification of UNCLOS and the development of a security dilemma as states in the region seek to defend their claims through the assertion of jurisdiction and resource rights. As the PLA continues to modernise, the military advantage China enjoys over other states in the region will continue to grow, allowing China to defend its claims (or capture the territory, depending on perspective). Recent exercises also contribute to China's effective assertion of jurisdiction over the islands, as well as deterring other claimant states from taking actions that go too far outside of established agreements. China can therefore be happy with a strategy that maintains its claims but will not bring a solution to the disputes in the short or even medium term.

The second aspect of the post Impeccable Incident is China's interactions with militaries outside of the region, predominantly the US. So why is it that the USNS Impeccable was harassed, and why is China sensitive to this presence? Lezyk Buszynski proposes that the reason for this sensitivity over US surveillance may be linked to the expansion of naval facilities at Sanya on Hainan Island, which is likely to base some of China's SSBNs. Ensuring that PLAN vessels can enter and leave naval bases on Hainan, without threat from US forces, will also require forces based in the Parcel's and other disputed islands in the South China Sea. ${ }^{343}$ To this end, the Impeccable Incident is merely an indicator of Chinese concerns about Hainan Island and its naval forces there, as well as being a result of its interpretation of its rights under UNCLOS. It is important to note that there have been no further incidents between the US Navy and Chinese naval forces, either civilian or military. Dating any shift in China's maritime policy from this incident is therefore an exercise in US centred thinking and not as useful an indication as it appears. ${ }^{344}$

There may also be a role for nationalist rhetoric and the need to show a strong hand in international disputes to assuage public opinion, but due to the opaque nature of Chinese decision making there is no reliable way to quantify its effect. Certainly in incidences like the collision between a Chinese fishing boat and Japanese coast Guard vessel near the Senkaku Islands, public

\footnotetext{
${ }^{343}$ Leszek Buszynski, "The South China Sea: Oil, Maritime Claims, and U.S.-China Strategic Rivalry," The Washington Quarterly 35, no. 2 (2012): 146.

${ }^{344}$ Fravel, "China's Strategy in the South China Sea."
} 
anger and protest resulted on both sides, but it is plausible that protests were allowed in China as a tool of foreign policy rather than influencing the policy itself. It is therefore not a factor that can account for the perceived shift in Chinese maritime behaviour and strategy.

\section{Conclusion}

China's assertive actions in the South China Sea as well as the Senkaku Islands and the undersea rocks between it and the South Korea are part of a concerted campaign to maintain Chinese claims on these areas. With China's ratification of UNCLOS it is now required to assert jurisdiction and control of disputed areas. This comes in the form of diplomatic protests against actions such as oil and gas explorations, para-military maritime organisations and PLAN patrols of the areas, and confrontations of the ships that are undertaking seen to be violating Chinese control of these areas. The recent dispute between the Philippines and China at Scarborough Shoal is just another example of this pattern; in that case it was the Philippines that asserted jurisdiction and China's move to assert its claims resulted in confrontation between the vessels of a Chinese para-military maritime organisation and the Philippine Navy. ${ }^{345}$ The Impeccable Incident is not indicative of this trend, but relates to China's wish to defend its nuclear deterrent and other naval forces based at Hainan Island. These actions all reflect a Chinese policy which seeks to defend the territory that it perceives to be its own, seeking to ensure that any negotiations over the future of the territory take place on its terms.

\footnotetext{
${ }^{345}$ Jane Perlez, "Dispute between China and Philippines over Island Becomes More Heated," The New York Times, 10 May 2012, accessed 17 May 2012, http://www.nytimes.com/2012/05/11/world/asia/china-philippines-dispute-overisland-gets-more-heated.html?_r=1. 


\section{CONCLUSION}

Understanding the trajectory of the Chinese Navy and the motivations behind the maritime strategy of the People's Republic is vital in understanding the practical outcomes. Incidents at sea and a naval fleet of growing sophistication are the most notable of these outcomes. By challenging the motivations assigned to Chinese, such as offensive realism's assertion that China has an end goal of establishing hegemony in its region, we can avoid policy prescriptions that are at best unnecessarily confrontational, and at worst dangerous. By understanding China's policy outside the assumptions of a power seeking state, we gain a more nuanced understanding of Chinese strategy and what it means for the world. This strategy is centred on the security of the state, and this security includes the South China Sea and China's claim on it.

This paper has allowed an application of defensive realism onto Chinese maritime strategy and has allowed us an insight into China as a security seeking state. It has shown that the assumptions of defensive realism are borne out by China's strategy and actions. China is seeking security in a number of areas; for a vulnerable coastline which holds the majority of its industry and economy, for areas that it considers its territory, and for the SLOCs vital to its economic growth. It can also be argued that it has sought security for its citizens overseas, but the evidence would suggest operations contributing to this outcome were primarily motivated by the needs of China's domestic audience. Aspects of the security dilemma can be seen in the build up of China's forces, as well as those of other states in the region. There are of course limits in the assertions that can be made about Chinese policy due to the opaque nature of the decision making process and military goals of the PRC, but the strong evidential base of this paper allows a fair degree of confidence in these findings. There are however areas of the literature that are found deficient by this paper. This is primarily in the area of offensive defensive balance, a theory which has not considered naval warfare to be of significance. As we move into a period where the USA is rebalancing towards Asia, and a security dilemma continues to develop amongst other states in the region, states that often share no land border, offensive defensive balance will be left out of the discussion without significant new contributions which take maritime conflict into account.

Chinese maritime strategy and actions on the past 20 years has been clearly influenced by international law and affected foreign relations. From an international legal perspective it is clear that UNCLOS is the key piece of international law that is influencing Chinese behaviour in the maritime sphere. However, there is a disconnect in China's actions as China seeks to maintain jurisdiction, and therefore claims to disputed territories as required by UNCLOS, but is not 
presently interested in allowing its claims to go through the arbitration in the method set out through UNCLOS. China is also in no hurry to conclude disputes in the South China Sea, due to its growing military advantage over the other claimant states. UNCLOS is therefore playing a role in the dispute, driving the actions of claimants but without regard to the dispute resolution methods set out in the convention. This is made worse by the differing view of EEZ rights that China and other states hold. China is essentially choosing which parts of UNCLOS it will respect, and this limits how useful UNCLOS will be to the ultimate resolution of these disputes. There are no means to enforce UNCLOS on China, and so the treaty will be of limited usefulness in solving these disputes.

It is equally clear that China's strategy in the South China Sea is a assertive one, though not in an exclusively military sense. This behaviour will continue to antagonise states, particularly Vietnam and the Philippines, and negatively affect perceptions of China in the rest of the world. China will need to balance its desire for a favourable outcome in these disputes and its desire to be seen in positive light, a desire which partially motivated its counter piracy operations in the Gulf of Aden.

The continued modernisation of the Chinese Navy is a fact of life which the world will have to come to terms with. With China's fleet still consisting predominantly of aging ships, based on even older designs, and which have in some cases been more dangerous to the crew than any adversary, this modernisation is necessary to create a navy which is the equivalent of any other contemporary forces. China's first operational aircraft carrier will be a significant milestone in this development, but it should not overshadow the other projects which will give the PLAN a backbone of modern surface combatants and submarines. These forces will be vital in ensuring that these aircraft carriers can play a viable role in conflicts without monopolising the entire navy for their protection. While China modernises its navy, it may be the growth of its paramilitary maritime organisations that is of most significance for China's neighbours. Their patrolling of disputed maritime territorial and harassing of vessels from other states is a key component of China's maritime strategy in these regions.

China's policy of challenging the actions of other states in the South China Sea is the most significant challenge to relations in the region. The disputes between China and Japan are taking a different track, and the disputes between South Korea and China are not as serious and confrontational as others. There is no way to close the capability gap between China and other disputant states. Due to China's preponderant size and economy, no other disputant state in the South China Sea is ever going to be able to match it. China strategy will successfully delay any 
DEFENSIVE REALISM AND CHINESE MARITIME STRATEGY

settling of the dispute. China is taking a long term view of the dispute and it is likely to succeed in forcing states to negotiate with it on its terms. The only chance for other states to negotiate a settlement of the dispute, on anything but a bilateral basis on China's terms, is a multilateral process through ASEAN and backed by the USA, but there are serious obstacles to such an effort. Claims in the South China Sea overlap with multiple states and so there are disputes between other disputant states, as well as with China. Efforts by ASEAN to engage with China on matters of security are also still limited, currently to less challenging matters such as maritime crime and disaster relief, and expanding them to matters of territorial sovereignty is a long way off. ${ }^{346}$ The US rebalancing into the region may help to ensure China takes no overt military actions, but these were already unlikely as war is bad for economic growth and growth is still China's key concern. The only way to ensure that China does not have its way in the dispute is therefore a multilateral solution, one that does not exist at present.

So what can states in the South China Sea dispute do to prevent a settlement in the region which is settled bilaterally between China and other states, and therefore on China's terms? The only hope to prevent this outcome is that states refuse to negotiate with China on these terms. There may be a temptation to negotiate so that exploration of hydrocarbon reserves can go ahead, even if it is on a cooperative basis; there are royalties to be earned that would be of great help to the states involved. The US can have a role in such efforts, reassuring allies that it supports a multilateral and rules based approach, while using what tools it has at its disposal to ensure that no state blinks first and negotiates with China. There are no realistic short term solutions to the territorial dispute in the South China Sea.

\footnotetext{
${ }^{346}$ Wu Shi Cun, "Maritime Security: Towards a Regional Code of Conduct?" (paper presented at the Council for Security Cooperation in the Asia Pacific 8th General Conference, Hanoi, 2011), 18 - 19.
} 


\section{BIBLIOGRAPHY}

"11 Chinese Naval Ships Cross High Seas between Okinawa Islands in 2 Days." Kyodo News, 9 June 2011, accessed 20 December 2011.

Abdelal, Rawi, and Jonathan Kirshner. "Strategy, Economic Relations, and the Definition of National Interests." Security Studies 9, no. 1-2 (1999): 119-56.

Aftergood, Steven. "J-8 (Jian-8 Fighter Aircraft 8) / F-8." Federation of American Scientists, 26 June 2000, accessed 5 October 2011, http://www.fas.org/man/dod-101/svs/ac/row/i-8.htm.

Agnihotri, Kamlesh Kumar. "China's Naval Aviation and Its Prospective Role in Blue Water Capabilities of the PLA Navy." Maritime Affairs: Journal of the National Maritime Foundation of India 6, no. 2 (2010): 23-48.

Annati, Massimo. "Amphibious Assault and Power Projection Platforms." Military Technology 31, no. 11 (2007): 64 - 74.

Bateman, Sam. "Clashes at Sea: When Chinese Vessels Harass Us Ships." RSIS Commentaries,no. 27 (2009), https://dr.ntu.edu.sg/bitstream/handle/10220/6093/RSIS0272009.pdf?sequence=1.

- - . "Perils of the Deep: The Dangers of Submarine Proliferation in the Seas of East Asia." Asian Security 7, no. 1 (2011): 61-84.

Beier, Marshall J. "Bear Facts and Dragon Boats: Rethinking the Modernization of Chinese Naval Power." Contemporary Security Policy 26, no. 2 (2005): 287 - 316.

Bellabona, Paola, and Francesca Spigarelli. "Moving from Open Door to Go Global: China Goes on the World Stage." International Journal of Chinese Culture and Management 1, no. 1 (2007): 93 - 107.

"Bgm-109 Tomahawk." Federation of American Scientists, accessed 24 August 2011, http://www.fas.org/man/dod-101/sys/smart/bgm-109.htm.

Biddle, Stephen. "Rebuilding the Foundations of Offense-Defense Theory." Journal of Politics 63, no. 3 (2001): 741-74.

Bitzinger, Richard A. "China's Syndrome : Chinese Military Modernization and the Rearming of Southeast Asia." RSIS Working Papers, no. 126 (2007): 1 - 31.

-- - "A New Arms Race? Explaining Recent Southeast Asian Military Acquisitions." Contemporary Southeast Asia 32, no. 1 (2010): 50(20).

Bluth, Christoph. "The Security Dilemma Revisited: A Paradigm for International Security in the TwentyFirst Century?" The International Journal of Human Rights 15, no. 8 (2011): 1362-77.

Brooks, Stephen G. "Dueling Realisms." International Organization 51, no. 3 (1997): 445-77.

Bussert, James C. "China's Phantom Fleet." Signal 66, no. 2 (2011): 43 - 46.

- - . "China Pursues Antisubmarine Warfare." Signal 59, no. 3 (2004): 59-62.

Bussert, James C. , and Bruce A. Elleman. People's Liberation Army Navy: Combat Systems Technology, 1949-2010. Annapolis: Naval Institute Press, 2011.

Buszynski, Leszek. "Rising Tensions in the South China Sea: Prospects for a Resolution of the Issue " Security Challenges 6, no. 2 (2010): 85 - 104.

---. "The South China Sea: Oil, Maritime Claims, and U.S.-China Strategic Rivalry." The Washington Quarterly 35, no. 2 (2012): 139-56.

Buszynski, Leszek, and Iskandar Sazlan. "Maritime Claims and Energy Cooperation in the South China Sea." Contemporary Southeast Asia 29, no. 1 (2007): 143-43-71.

Chan, Hok-lam. "The Chien-Wen, Yung-Lo, Hung-Hsi, and Hsüan-Te Reigns, 1399-1435." In The Cambridge History of China Vol. 7, Part 1: The Ming Dynasty, 1368-1644, Part I, edited by Frederick W. Mote and Denis Twitchett, 182-304. Cambridge: Cambridge University Press, 1998.

Chang, Felix K. "China's Naval Rise and the South China Sea: An Operational Assessment." Orbis 56, no. 1 (2012): 19-38.

- - . "In Defense of Singapore." Orbis 47, no. 1 (2003): 107-23.

Chang, Teh-Kuang. "China's Claim of Sovereignty over Spratly and Paracel Islands: A Historical and Legal Perspective." Case Western Reserve Journal of International Law 23, no. 1 (1991): 399 - 420.

Chase, Michael S. "Chinese Suspicion and Us Intentions." Survival 53, no. 3 (2011): 133-50.

"China's First Aircraft Carrier Enters Service." BBC News, 25 September 2012, accessed 25 September 2012, http://www.bbc.co.uk/news/world-asia-china-19710040. 
DEFENSIVE REALISM AND CHINESE MARITIME STRATEGY

"China Demands S. Korea Stop Hoisting Sunken Ship near leodo." Yonhap News Agency, 27 July 2011, accessed 18 January 2012, http://english.yonhapnews.co.kr/national/2011/07/27/19/0301000000AEN20110727006300315 F.HTML.

"China Dispatches Largest Patrol Ship to East China Sea." The Telegraph, 14 December 2012, accessed 19 January 2012, http://www.telegraph.co.uk/news/worldnews/asia/china/8955066/Chinadispatches-largest-patrol-ship-to-East-China-Sea.html.

"China Sub Stalked U.S. Fleet." The Washington Times, 13 November 2006, accessed 13 December 2011, http://www.washingtontimes.com/news/2006/nov/13/20061113-121539-3317r/?page=all.

"China Violates Sovereignty." Vietnam News, 30 May 2011, accessed 5 January 2012, http://vietnamnews.vnanet.vn/Politics-Laws/211778/China-violates-sovereignty.html.

"China, Russia Hold Joint Naval Military Exercise in Gulf of Aden." Xinhua, 20 September 2009, accessed 6 June 2012, http://news.xinhuanet.com/english/2009-09/20/content 12081764.htm.

"Chinese Fishermen 'Stab South Korean Coast Guards'." BBC News, 12 December 2011, accessed 13 December 2011, http://www.bbc.co.uk/news/world-asia-16134647.

"Chinese Navy Frigate Arrives Waters Off Libya for Escort Mission." Xinhua, 1 March 2011, accessed 8 December 2011, http://news.xinhuanet.com/english2010/china/2011-03/01/c 13756148.htm.

"Chinese Navy Vessels Cross High Seas between Okinawa Islands." Kyodo News, 8 June 2011, accessed 19 December 2011.

"Chinese Patrol Boats Enter Japanese Waters Off Senkaku Islands." Kyodo News, 24 August 2011, accessed 10 January 2012.

"Chinese Ships 'Harass' U.S. Vessel." BBC News, 9 March 2009, accessed 4 January 2012, http://news.bbc.co.uk/2/hi/7933171.stm.

Christensen, Thomas J. "The Advantages of an Assertive China: Responding to Beijing's Abrasive Diplomacy." Foreign Affairs 90, no. 2 (2011): 54.

- - . "China, the U.S.-Japan Alliance, and the Security Dilemma in East Asia." International Security 23, no. 4 (1999): 49-80.

Cliff, Roger. "The Development of China's Air Force Capabilities." 8. Santa Monica: RAND Corporation, 2010.

Cole, Bernard D. The Great Wall at Sea. 2nd ed. Annapolis: Naval Institute Press, 2010.

- - . "The People's Liberation Army Navy after Half a Century: Lessons Learned in Beijing." In The Lessons of History: The Chinese People's Liberation Army at 75, edited by Laurie Burkitt, Andrew Scobell and Larry M. Wortzel, 157 - 91. Carlisle, PA: Strategic Studies Institute, United States Army War College, 2003.

Cole, Bernard D. . "Rightsizing the People's Liberation Army Navy: How Much Naval Force Will Beijing Deploy by 2016?" Asia Policy 4 (2007): 84 - 88

Collin, Koh Swee Lean. "The Philippines' Navy Challenge." The Diplomat, 27 December 2011, accessed 4 January 2012, http://the-diplomat.com/flashpoints-blog/2011/12/27/thephilippines\%E2\%80\%99-navy-challenge/.

Collins, Gabriel, and Andrew Erickson. "Missile Frigate Xuzhou Transits Suez Canal, to Arrive Off Libya Wednesday 2 March: China's First Operational Deployment to Mediterranean Addresses Libya's Evolving Security Situation." China Sign Post, 30 July 2011, accessed 7 December 2011, http://www.chinasignpost.com/2011/02/missile-frigate-xuzhou-transits-suez-canal-to-arrive-offlibya-wednesday-2-march-china\%E2\%80\%99s-first-operational-deployment-to-mediterraneanaddresses-libya\%E2\%80\%99s-evolving-security-situation/.

Collins, Gabriel, Andrew Erickson, Lyle Goldstein, and William Murray. "Chinese Evaluations of the U.S. Navy Submarine Force." Naval War College Review 61, no. 1 (2008): 68-86.

Collins, Gabriel, and Michael C. Grubb. A Comprehensive Survey of China's Dynamic Shipbuilding Industry: Commercial Development and Strategic Implications. Vol. 1, China Maitime Studies. New Port: China Maritime Studies Institute, U.S. Naval War College, 2008.

Cooper, Cortez A. The PLA Navy's "New Historic Missions": Expanding Capabilities for a Re-Emergent Maritime Power. Santa Monica, CA: RAND Corporation, 2009. 
Cote, Owen R. "Assessing the Undersea Balance between the U.S. And China." MIT Center for International Studies, February 2011, accessed 30 December 2011, http://web.mit.edu/ssp/publications/working papers/Undersea\%20Balance\%20WP11-1.pdf.

Cun, Wu Shi. "Maritime Security: Towards a Regional Code of Conduct?" Paper presented at the Council for Security Cooperation in the Asia Pacific 8th General Conference, Hanoi, 2011.

Danlu, Tang. "China's First Aircraft Carrier Commissioned." Xinhua, 25 September 2012, accessed 2 October 2012, http://news.xinhuanet.com/english/china/2012-09/25/c 131871538.htm.

Defense, Office of the Secretary of. "Military and Security Developments Involving the People's Republic of China 2011." 84. Washington, D.C.: Department of Defence, 2011.

Demick, Barbara. "Chinese Naval Maneuvers Seen as Warning to Vietnam." Los Angeles Time, 18 June 2011, accessed 6 June 2012, http://articles.latimes.com/2011/jun/18/world/la-fg-chinavietnam-20110618.

Ding, Arthur S. "China's Growing Military Capability in Search of a Strategy." The International Spectator: Italian Journal of International Affairs 44, no. 2 (2009): 95 - 110.

- - . "The Lessons of the 1995-1996 Taiwan Stratit Crisis: Developing a New Strategy Towards the United States and Taiwan." In The Lessons of History: The Chinese People's Liberation Army at 75, edited by Laurie Burkitt, Andrew Scobell and Larry M. Wortzel, 379-402. Carlisle, PA: Strategic Studies Institute, United States Army War College, 2003.

Dutton, Peter. "An Assessment of the Effectiveness of Current Maritime Security Frameworks and Mechanisms in the South China Sea." Paper presented at the The South China Sea Reader, Manila, Philippines, 2011.

Eaglen, Mackenzie, and Jon Rodeback. "Submarine Arms Race in the Pacific: The Chinese Challenge to U.S. Undersea Supremacy." Backgrounder, no. 2367 (2 February 2010): 1 - 13.

Encyclopedia of World Biography: Alfred Thayer Mahan. 2 ed. Vol. 10. Detroit: Gale, 2004.

Erickson, Andrew S. "Chinese Sea Power in Action: The Counterpiracy Mission in the Gulf of Aden and Beyond." In The PLA at Home and Abroad: Assessing the Operational Capabilities of China's Military, edited by Roy Kamphausen, David Lai and Andrew Scobell, 295 - 376. Carlisle PA: Strategic Studies Institute, United States Army War College, 2010.

Erickson, Andrew S., and Andrew R. Wilson. "China's Aircraft Carrier Dilemma." Naval War College Review 59, no. 4 (2006): 12.

Fairbank, John K. "The Creation of the Treaty System." In The Cambridge History of China, Volume 10, Part 1: Late Ch'ing 1800-1911, Part I, edited by John K. Fairbank, 213-63. Cambridge: Cambridge University Press, 1978.

Feigenbaum, Evan A. "China's Pakistan Conundrum." Foreign Affairs, 4 December 2011, accessed 7 December 2011, http://www.foreignaffairs.com/articles/136718/evan-a-feigenbaum/chinaspakistan-conundrum.

Fisher, Richard D., Jr. China's Military Modernization: Building for Regional and Global Reach. Westport: Praeger Security International, 2008.

France-Presse, Agence. "Japan Calls for China to Explain Aircraft Carrier." Defence News, 13 August 2011, accessed http://www.defensenews.com/story.php?i=7374470\&c=ASI\&s=SEA.

-- - "U.S. Asks China to Explain Need for Carrier." Defence News, 10 August 2011, accessed 1 August 2011, http://www.defensenews.com/story.php?i=7357523\&amp;c=SEA\&amp;s=TOP.

Fravel, M. Taylor. "China's Strategy in the South China Sea." Contemporary Southeast Asia 33, no. 3 (2011): 292 - 319.

---. "Economic Growth, Regime Insecurity, and Military Strategy: Explaining the Rise of Noncombat Operations in China." Asian Security 7, no. 3 (2011): 177-200.

Gertz, Bill. "China Begins to Build Its Own Aircraft Carrier." The Washington Times, 1 August 2011, accessed 10 October 2011, http://www.washingtontimes.com/news/2011/aug/1/china-beginsto-build-its-own-aircraft-carrier/?page=all.

Glaser, Charles L., and Chaim Kaufmann. "What Is the Offense-Defense Balance and Can We Measure It?" International Security 22, no. 4 (1998): 44-82.

Glosny, Michael A., Phillip C. Saunders, and Robert S. Ross. "Debating China's Naval Nationalism." International Security 35, no. 2 (2010): 161-75. 
DEFENSIVE REALISM AND CHINESE MARITIME STRATEGY

Goldstein, Lyle, and William Murray. "Undersea Dragons: China's Maturing Submarine Force." International Security 28, no. 4 (2004): 161-96.

Gomez, Jim. "China Warns Neighbors: Stop Oil Search in Spratlys." Bloomberg Businessweek, 9 June 2011, accessed 5 January 2012, http://www.businessweek.com/ap/financialnews/D9NOD2LG1.htm.

Guoxing, Ji. "The Legality of The "Impeccable Incident"." China Security 5, no. 2 (2009): 16 - 21.

Heywood, Andrew. Global Politics. New York: Palgrave Macmillan, 2011.

Hiyama, Hiroshi. "F-35 Wins Japan Fighter Competition." Defense News, 20 December 2011, accessed 4 May 2012, http://www.defensenews.com/article/20111220/DEFSECT01/112200306/F-35-WinsJapan-Fighter-Competition.

Hobson, Rolf. Imperialism at Sea: Naval Strategic Thought, the Ideology of Sea Power, and the Tirpitz Plan, 1875-1914. Boston: Brill Academic Publishers, 2002.

Holmes, James R. "China's Way of Naval War: Mahan's Logic, Mao's Grammar." Comparative Strategy 28, no. 3 (2009): 217 - 43.

- - . "Schelling Goes to Sea: Managing Perceptions in China's 'Contested Zone'." Defence Studies 9, no. 2 (2009): 189 - 206.

Holmes, James R., and Toshi Yoshihara. "Authors' Response: Varieties of Mahanian Experience." Asia Policy 12 (2011): 161 - 68.

- - - "The Influence of Mahan Upon China's Maritime Strategy." Comparative Strategy 24, no. 1 (2005): 23-51.

Holmes, James, and Toshi Yoshihara. "Mao Zedong, Meet Alfred Thayer Mahan: Strategic Theory and Chinese Sea Power." Australian Defence Force Journal, no. 171 (2006): 33 - 50.

Hughes, Christopher W. "Japan's Military Modernisation: A Quiet Japan-China Arms Race and Global Power Projection." Asia-Pacific Review 16, no. 1 (2009): 84-99.

_- - "Japan's Response to China's Rise: Regional Engagement, Global Containment, Dangers of Collision." International Affairs 85, no. 4 (2009): 837-56.

Hurrell, Andrew. "Hegemony, Liberalism and Global Order: What Space for Would-Be Great Powers?" International Affairs 82, no. 1 (2006): 1-19.

"Japan to Monitor Chinese Navy Vessels near Okinawa." Kyodo News, 10 June 2011, accessed 20 December 2011.

Jencks, Harlan W. ""People's War under Modern Conditions": Wishful Thinking, National Suicide, or Effective Deterrent?" The China Quarterly, no. 98 (1984): 305-19.

Jing, Fu. "Home Thoughts after Journey out of Danger." China Daily, 3 March 2011, accessed 8 December 2011, http://www.chinadaily.com.cn/cndy/2011-03/03/content 12106130.htm.

Jisi, Wang. "China's Search for a Grand Strategy: A Rising Great Power Finds Its Way." Foreign Affairs 90, no. 2 (2011): 68-79.

Khurana, Gurpreet S. "China's 'String of Pearls' in the Indian Ocean and Its Security Implications." Strategic Analysis 32, no. 1 (2008): 1-39.

Kiselycznyk, Michael, and Phillip C. Saunders. Civil-Military Relations in China: Assessing the Pla's Role in Elite Politics. Edited by Phillip C. Saunders. Vol. 2, China Strategic Perspectives. Washington, D.C.: National Defense University Press, 2010.

Koh, Yoree. "Maritime Collision Fuels China-Japan Tension." Wall Street Journal, 8 September 2010, accessed 6 January 2012.

Kraska, James. "Coalition Strategy and the Pirates of the Gulf of Aden and the Red Sea." Comparative Strategy 28, no. 3 (2009): 197-216.

- - . "How the United States Lost the Naval War of 2015." Orbis 54, no. 1 (2010): 35-45.

- - . "Sovereignty at Sea." Survival 51, no. 3 (2009): 13-18.

Kuo, Ting-yee, and Kwang-Ching Liu. "Self-Strengthening: The Pursuit of Western Technology." In The Cambridge History of China, Volume 10, Part 1: Late Ch'ing 1800-1911, Part I, edited by John K. Fairbank, 491-542. Cambridge: Cambridge University Press, 1978.

LaFeber, Walter. "A Note on The "Mercantilistic Imperialism" Of Alfred Thayer Mahan." The Mississippi Valley Historical Review 48, no. 4 (1962): 674-85.

Lai, David. "Chinese Military Going Global." China Security 5, no. 1 (2009): 7.

Lanteigne, Marc. "China's Maritime Security and the "Malacca Dilemma"." Asian Security 4, no. 2 (2008): 143-61. 
Le Mière, Christian. "Policing the Waves: Maritime Paramilitaries in the Asia-Pacific." Survival 53, no. 1 (2011): 133-46.

- - . "The Return of Gunboat Diplomacy." Survival 53, no. 5 (2011): 53-68.

Lee, Se Young. "Seoul Beefs up Steps to Fight Illegal Fishing." The Wall Street Journal, 27 December 2011, accessed 19 January 2012, http://online.wsj.com/article/SB10001424052970203391104577122010640638178.html.

Lennox, Patrick. Contemporary Piracy Off the Horn of Africa. Calgary: Canadian Defence and Foreign Affairs Institute, 2008.

"Leodo Ocean Research Station: History of Construction." Korea Hydrographic and Oceanographic Administration, accessed 18 January 2012, http://ieodo.khoa.go.kr/eng/open content/introduce/history.asp.

Lewis, John w., and Xue Litati. China's Strategic Seapower: The Politics of Force Modernization in the Nuclear Age. Stanford: Stanford University Press, 1994.

Li, Nan. Chinese Civil-Military Relations in the Post-Deng Era: Implications for Crisis Management and Naval Modernization, China Maritime Studies. Newport: U.S. Naval War College, 2010.

- - - "The Evolution of China's Naval Strategy and Capabilities: From "near Coast" and "near Seas" to "Far Seas"." Asian Security 5, no. 2 (2009): 144 - 69.

Li, Nan, and Christopher Weuve. "China's Aircraft Carrier Ambitions: An Update." Naval War College Review 63, no. 1 (2010): 13.

Li, Xiaobing. A History of the Modern Chinese Army. Lexington: The University Press of Kentucky, 2007.

Lim, Yves-Heng. "The Driving Forces Behind China's Naval Modernization." Comparative Strategy 30, no. 2 (2011): 105-20.

Lin-Greenberg, Erik. "Dragon Boats: Assessing China's Anti-Piracy Operations in the Gulf of Aden." Defense \& Security Analysis 26, no. 2 (2010): 213 - 30.

- - . "Offensive Airpower with Chinese Characteristics: Development, Capabilities, and Intentions." Air \& Space Power Journal 21, no. 3 (2007): 67(11).

Lina, Yang. "China Sends Leading Patrol Ship to East China Sea on Maiden Voyage." Xiahua, 13 December 2011, accessed 19 January 2012, http://news.xinhuanet.com/english/china/201112/13/c 131304219.htm.

Liu, Kwang-Ching, and Richard J. Smith. "The Military Challenge: The North-West and the Coast." In The Cambridge History of China, Volume 11, Part 2: Late Ch'ing, 1800-1911, edited by Jonh K. Fairbank and Kwang-Ching Liu, 202-73. Cambridge: Cambridge University Press, 1980.

Liu, Nengye. "Law on Island Protection of People's Republic of China." Environmental Law Network International Review 2 (2010).

Lundquist, David. "Nationalism, History \& Policy." The Diplomat, 18 December 2011, accessed 11 January 2012, http://the-diplomat.com/china-power/2011/12/18/nationalism-history-foreign-policy/.

Mastro, Oriana Skylar. "Signaling and Military Provocation in Chinese National Security Strategy: A Closer Look at the Impeccable Incident." Journal of Strategic Studies 34, no. 2 (2011): 219-44.

McCormack, Gavan. "Small Islands - Big Problem: Senkaku/Diaoyu and the Weight of History and Geography in China-Japan Relations." Japan Focus, 3 January 2011, accessed 5 January 2012, http://japanfocus.org/-Gavan-McCormack/3464.

McDevitt, Michael. "Is the PLA Navy Channeling Mahan? And Does It Matter?" Asia Policy 12 (2011): 149 - 53.

McVadon, Eric A. "China's Maturing Navy." Naval War College Review 59, no. 2 (2006): 90.

Mearsheimer, John. "China's Unpeaceful Rise." Current History 105, no. 690 (2006): 160 - 62.

- - The Tragedy of Great Power Politics. New York: W. W. Norton \& Company, 2001.

Medeiros, Evan S., Roger Cliff, Keith Crane, and James C. Mulvenon. A New Direction for China's Defense Industry. Santa Monica: RAND Corporation, 2005.

Mingjiang, Li. "Security in the South China Sea: China's Balancing Act and New Regional Dynamics." RSIS Working Paper 149 (2008): 1 - 22.

Minnick, Wendell. "Sea Trials Begin for Chinese Aircraft Carrier." Defence News, 9 August 2011, accessed 9 August 2011, http://www.defensenews.com/story.php?i=7350123\&c=ASI\&s=SEA.

Mizokami, Kyle. "The Plan's Annual Miyakojima Run, 2011." New Pacific Institute, 23 June 2011, accessed 5 June 2012, http://isw.newpacificinstitute.org/?p=6848. 
DEFENSIVE REALISM AND CHINESE MARITIME STRATEGY

Morris, lan. "After Beijing Sends a Frigate to the Med, a Leading Author Poses a Chilling Question... How Long until a Chinese Aircraft Carrier Sails up the Thames?" The Daily Mail, 5 March 2011, accessed 7 December 2011, http://www.dailymail.co.uk/news/article-1363440/After-Beijingsends-frigate-Med-leading-author-poses-chilling-question--How-long-Chinese-aircraft-carriersails-Thames.html.

Mulvenon, James. "Chairman Hu and the Pla's "New Historic Missions"." China Leadership Monitor, no. 27 (2009): 1-11.

Narine, Shaun. "Institutional Theory and Southeast Asia: The Case of Asean." World Affairs 161, no. 1 (1998): 33-47.

Neher, Patrick J., Raul A. Pedrozo, and J. Ashley Roach. "In Defence of High Seas Freedoms." RSIS Commentaries,no. 31 (2009), http://dr.ntu.edu.sg/bitstream/handle/10220/6075/RSIS0312009.pdf?sequence=1.

Nellas, Demetris. "2,800 Chinese Evacuated from Libya to Crete." The Guardian, 26 February 2011, accessed 12 December 2011, http://www.guardian.co.uk/world/feedarticle/9519422.

Nicoll, Alexander. "China's Three-Point Naval Strategy." IISS Strategic Comments 16, no. 37 (2010): 1 - 3.

-- - "Chinese Navy's New Strategy in Action." IISS Strategic Comments 16, no. 16 (2010): 1 - 3.

Norris, Robert S., and Hans M. Kristensen. "Chinese Nuclear Forces, 2010." Bulletin of the Atomic Scientists 66, no. 6 (2010): 134-41.

O'Rourke, Ronald. China Naval Modernization: Implications for U.S. Navy Capabilities-Background and Issues for Congress. Washington D.C.: Congressional Research Service, 2011.

-- . Navy DDG-51 and DDG-1000 Destroyer Programs: Background and Issues for Congress. Washington, DC: Congressional Research Service, 2011.

O'Hara, Gerald. "Cyber-Espionage: A Growing Threat to the American Economy." CommLaw Conspectus 19 (2010): 241-75.

Owen, Nick A., and Clive H. Schofield. "Disputed South China Sea Hydrocarbons in Perspective." Marine Policy 36, no. 3 (2012): 809-22.

Packard, George R. "The United States-Japan Security Treaty at 50: Still a Grand Bargain?" Foreign Affairs 89, no. 2 (2010): 92 - 103.

Pedrozo, Raul. "Close Encounters at Sea: The Usns Impeccable Incident." Naval War College Review 62, no. 3 (2009): 101 - 11.

"The People's Liberation Army Navy: A Modern Navy with Chinese Characteristics." 46. Suitland, MD: The Office of Naval Intelligence, 2009.

Perlez, Jane. "Dispute between China and Philippines over Island Becomes More Heated." The New York Times, 10 May 2012, accessed 17 May 2012, http://www.nytimes.com/2012/05/11/world/asia/china-philippines-dispute-over-island-getsmore-heated.html? $r=1$.

"PLA Naval Fleet to Go for Exercise in Western Pacific." Ministry of National Defence, 24 November 2011, accessed 5 June 2012, http://eng.mod.gov.cn/Press/2011-11/24/content 4318685.htm.

"PLA Navy to Conduct Drill in West Pacific Int'I Waters in Mid to Late June." Ministry of National Defence, The People's Republic of China, 10 June 2011, accessed 20 December 2011, http://eng.mod.gov.cn/DefenseNews/2011-06/10/content 4246051.htm.

Powell, Ralph L. "Great Powers and Atomic Bombs Are "Paper Tigers"." The China Quarterly, no. 23 (1965): 55-63.

- - " "Maoist Military Doctrines." Asian Survey 8, no. 4 (1968): 239-62.

Pradun, Vitaliy O. "From Bottle Rockets to Lightning Bolts: China's Missile Revolution and PLA Strategy against U.S. Military Intervention." Naval War College Review 64, no. 2 (2011): 7.

Press, Associated. "Japanese Jets Scramble against Chinese Planes near Senkakus." Breitbart, 2 March 2011, accessed 5 January 2012, http://www.breitbart.com/article.php?id=D9LN57T80\&show article=1.

Rahman, Chris, and Martin Tsamenyi. "A Strategic Perspective on Security and Naval Issues in the South China Sea." Ocean Development \& International Law 41, no. 4 (2010): 315-33.

Raine, Sarah. "Beijing's South China Sea Debate." Survival 53, no. 5 (2011): 69-88.

Rendall, Matthew. "Defensive Realism and the Concert of Europe." Review of International Studies 32, no. 3 (2006): 523-40. 
Robinson, Thomas W. "Chinese Military Modernization in the 1980s." The China Quarterly, no. 90 (1982): 231-52.

Rochlin, Gene I., Todd R. La Porte, and Karlene H. Roberts. "The Self-Designing High-Reliability Organization: Aircraft Carrier Flight Operations at Sea." Naval War College Review Autumn (1987): 76-90.

Rosecrance, Richard. "Power and International Relations: The Rise of China and Its Effects." International Studies Perspectives 7, no. 1 (2006): 31-35.

Ross, Robert S. "The 1995-96 Taiwan Strait Confrontation: Coercion, Credibility, and the Use of Force." International Security 25, no. 2 (2000): 87-123.

- - . "Balance of Power Politics and the Rise of China: Accommodation and Balancing in East Asia." Security Studies 15, no. 3 (2006): 355-95.

- - . "China's Naval Nationalism: Sources, Prospects, and the U.S. Response." International Security 34, no. 2 (2009): 46-81.

Rowan, Joshua P. "The U.S.-Japan Security Alliance, Asean, and the South China Sea Dispute." Asian Survey 45, no. 3 (2005): 414-36.

Roy, Denny. "Southeast Asia and China: Balancing or Bandwagoning?" Contemporary Southeast Asia 27, no. 2 (2005): 305-22.

Rozman, Gilbert. "Chinese Strategic Thinking on Multilateral Regional Security in Northeast Asia." Orbis 55, no. 2 (2011): 298-313.

Russell, Greg. "Alfred Thayer Mahan and American Geopolitics: The Conservatism and Realism of an Imperialist." Geopolitics 11, no. 1 (2006): 119-40.

"Russia Sends Planes, Ship to Evacuate Foreigners from Riot-Struck Libya." RIA Novosti, 22 February 2011, accessed 9 December 2011, http://en.rian.ru/world/20110222/162721789.html.

Samuels, Richard J. "“New Fighting Power!” Japan's Growing Maritime Capabilities and East Asian Security." International Security 32, no. 3 (2008): 84-112.

Schmidt, Brian C. "Realism as Tragedy." Review of International Studies 30, no. 3 (2004): 427-41.

Schweller, Randall L. "Bandwagoning for Profit: Bringing the Revisionist State Back In." International Security 19, no. 1 (1994): 72-107.

Scobell, Andrew. "Show of Force: Chinese Soldiers, Statesmen, and the 1995-1996 Taiwan Strait Crisis." Political Science Quarterly 115, no. 2 (2000): 227-46.

Scott, David. India's Drive for a 'Blue Water' Navy. Vol. 10, 20082008.

"Second Report from the Commission to the Council on the Situation in World Shipbuilding." edited by Commission of the European Communities, 33. Brussels: EUR-Lex, 2000.

"Ships, Sensors, and Weapons: Undersea Warfare Programs Target an Expeditionary Future." Undersea Warfare, 2001, accessed 4 January 2012, http://www.navy.mil/navydata/cno/n87/usw/issue 11/ship sensors weapons.html.

Speed, Elizabeth. Chinese Naval Power and East Asian Security, Working Paper No. 11. Vancouver: Institute of International Relations University of British Columbia, 1995.

Storey, Ian, and You Ji. "China's Aircraft Carrier Ambitions: Seeking Truth from Rumours." Air Power Journal 1, no. 2 (2004): 22.

Swaine, Michael D., and M. Taylor Fravel. "China's Assertive Behavior-Part Two: The Maritime Periphery." China Leadership Monitor, no. 35 (2011): 1 - 29.

Taliaferro, Jeffrey W. "Security Seeking under Anarchy: Defensive Realism Revisited." International Security 25, no. 3 (2000): 128-61.

Tang, Shiping. "The Security Dilemma: A Conceptual Analysis." Security Studies 18, no. 3 (2009): 587-623.

Thayer, Carlyle A. "Recent Developments in the South China Sea: Grounds for Cautious Optimism." RSIS Working Paper No. 220 (2010): 1 - 33.

Tkacik, John. J. "Trojan Dragon: China's Cyber Threat." Executive Summery Backgrounder,no. 2106 (2008), http://www.policyarchive.org/handle/10207/bitstreams/13468.pdf.

Ueki, Chikako Kawakatsu. "The Rise Of "China Threat" Arguments." Massachusetts Institute of Technology, 2009.

Upadhyaya, Shishir. "Piracy in the Gulf of Aden: Naval Challenges." Maritime Affairs: Journal of the National Maritime Foundation of India 6, no. 2 (2010): 133-47. 
DEFENSIVE REALISM AND CHINESE MARITIME STRATEGY

Valencia, Mark. "The Impeccable Incident: Truth and Consequences." China Security 5, no. 2 (2009): $22-$ 28.

Valencia, Mark J. "The East China Sea Dispute: Context, Claims, Issues, and Possible Solutions." Asian Perspective 31, no. 1 (2007): 127 - 67.

- - . "The South China Sea: Back to the Future." Global Asia 5, no. 4 (2010): 8 - 15.

Valeriano, Brandon. "The Tragedy of Offensive Realism: Testing Aggressive Power Politics Models." International Interactions 35, no. 2 (2009): 179-206.

Van Dyke, Jon M. "Military Ships and Planes Operating in the Exclusive Economic Zone of Another Country." Marine Policy 28, no. 1 (2004): 29-39.

van Tol, Jan. Airsea Battle: A Point-of-Departure Operational Concept. Washington, D.C.: Center for Strategic and Budgetary Assessments, 2010.

Vasquez, John A. "The Realist Paradigm and Degenerative Versus Progressive Research Programs: An Appraisal of Neotraditional Research on Waltz's Balancing Proposition." The American Political Science Review 91, no. 4 (1997): 899-912.

"Vietnam Says Chinese Boat Harassed Survey Ship; China Disputes." Bloomberg News, 10 June 2011, accessed 5 January 2012, http://www.bloomberg.com/news/2011-06-05/china-reassures-itsneighbors-after-clashes-over-claims-in-south-china-sea.html.

Wakeman, Frederic. "The Canton Trade and the Opium War." In The Cambridge History of China, Volume 10, Part 1: Late Ch'ing 1800-1911, Part I, edited by John K. Fairbank, 163-212. Cambridge: Cambridge University Press, 1978.

Walt, Stephen M. "Alliance Formation and the Balance of World Power." International Security 9, no. 4 (1985): 3-43.

- - . "International Relations: One World, Many Theories." Foreign Policy, no. 110 (1998): 29-46.

Waltz, Kenneth N. Theory of International Politics. Reading MA: Addison-Wesley Publishing, 1979.

Wang, Ying. "China Tells U.S. Not to Internationalize South China Sea Issue." Bloomberg, July 252010 , accessed 21 July 2011, http://www.businessweek.com/news/2010-07-25/china-tells-u-s-not-tointernationalize-south-china-sea-issue.html.

Wang, Zheng. "Understanding China's Military Strategy: The Challenge to Researchers." Asia Policy 12 (2011): 157 - 60.

Watts, Jonathan. "South Korean Coastguard Stabbed to Death While Seizing Chinese Boat." The Guardian, 12 December 2011, accessed 19 January 2012, http://www.guardian.co.uk/environment/2011/dec/12/south-korean-coastguard-stabbed-boat.

Weiss, Kenneth G. The Sea Is Red: The Sino-Soviet Rivalry and Its Naval Dimension, Professional Papper 421. Alexandria, VA Center for Naval Analyses, 1984.

Weitz, Richard. "Demise of Russian-Chinese Arms Relationship and Its Korean Implications." International Journal of Korean Unification Studies 18, no. 2 (2009): 86 - 120.

Wilson, Brian. "An Avoidable Maritime Conflict: Disputes Regarding Military Activities in the Exclusive Economic Zone." Journal of Maritime Law and Commerce 41, no. 3 (2010): 421 - 37.

Wong, Edward. "Beijing Warns U.S. About South China Sea Disputes." New York Times, 22 June 2011, accessed 16 January 2012, http://www.nytimes.com/2011/06/23/world/asia/23china.html? r=2\&ref=world.

- - . "China Navy Reaches Far, Unsettling the Region." The New York Times, accessed 15 June, http://www.nytimes.com/2011/06/15/world/asia/15china.html? r=1\&ref=world.

- - . "Chinese Military Seeks to Extend Its Naval Power." The New York Times, 23 April 2010, accessed 14 December 2011, http://www.nytimes.com/2010/04/24/world/asia/24navy.html?pagewanted=all.

Xiang, Zhang. "Greek Ship Docks at Crete with Evacuatees from Libya." Xinhua, 2 March 2011, accessed 8 Decmber 2011, http://news.xinhuanet.com/english2010/china/2011-03/02/c 13758156.htm.

Xiaohuo, Cui, and Zhang Haizhou. "Top Military Officers Lash out at Us Espionage." China Daily, 11 March 2009, accessed 4 January 2012, http://www.chinadaily.com.cn/china/200903/11/content 7565312.htm.

Yonhap. "China Overtakes S. Korea as World's Largest Shipbuilder in 2010." The Asian Age, 13 January 2011, accessed 11 October 2011, http://www.asianage.com/international/china-overtakes-skorea-worlds-top-shipbuilder-2010-120. 
Yoshihara, Toshi, and James Holmes. "Command of the Sea with Chinese Characteristics." Orbis 49, no. 4 (2005): 677-94.

Yoshihara, Toshi, and James R. Holmes. "The Next Arms Race." The Diplomat, accessed 1 December 2011, http://apac2020.the-diplomat.com/feature/the-next-arms-race/.

-- - Red Star over the Pacific: China's Rise and the Challenge to U.S. Maritime Strategy. Annapolis: Naval Institute Press, 2010.

You, Ji. "The Evolution of China's Maritime Combat Doctrines and Models : 1949-2001." RSIS Working Papers 02, no. 22 (2002): 41.

Young, Nick. "Chinese Anti-Ship Missile Analysis Shows Us Navy Carriers at Tangible Risk." Defence IQ, accessed 28 September 2011, http://www.defenceiq.com/naval-and-maritimedefence/articles/chinese-anti-ship-missile-analysis-shows-us-navy-c/.

Yung, Christopher D., Ross Rustici, Isaac Kardon, and Joshua Wiseman. China's out of Area Naval Operations: Case Studies, Trajectories, Obstacles, and Potential Solutions. Vol. 3, Inss China Strategic Perspectives. Washington. D.C.: National Defence University Press, 2010. 